Prepared in cooperation with the

New Jersey Department of Environmental Protection

\title{
Relation of Water Quality to Land Use in the Drainage Basins of Six Tributaries to the Lower Delaware River, New Jersey, 2002-07
}

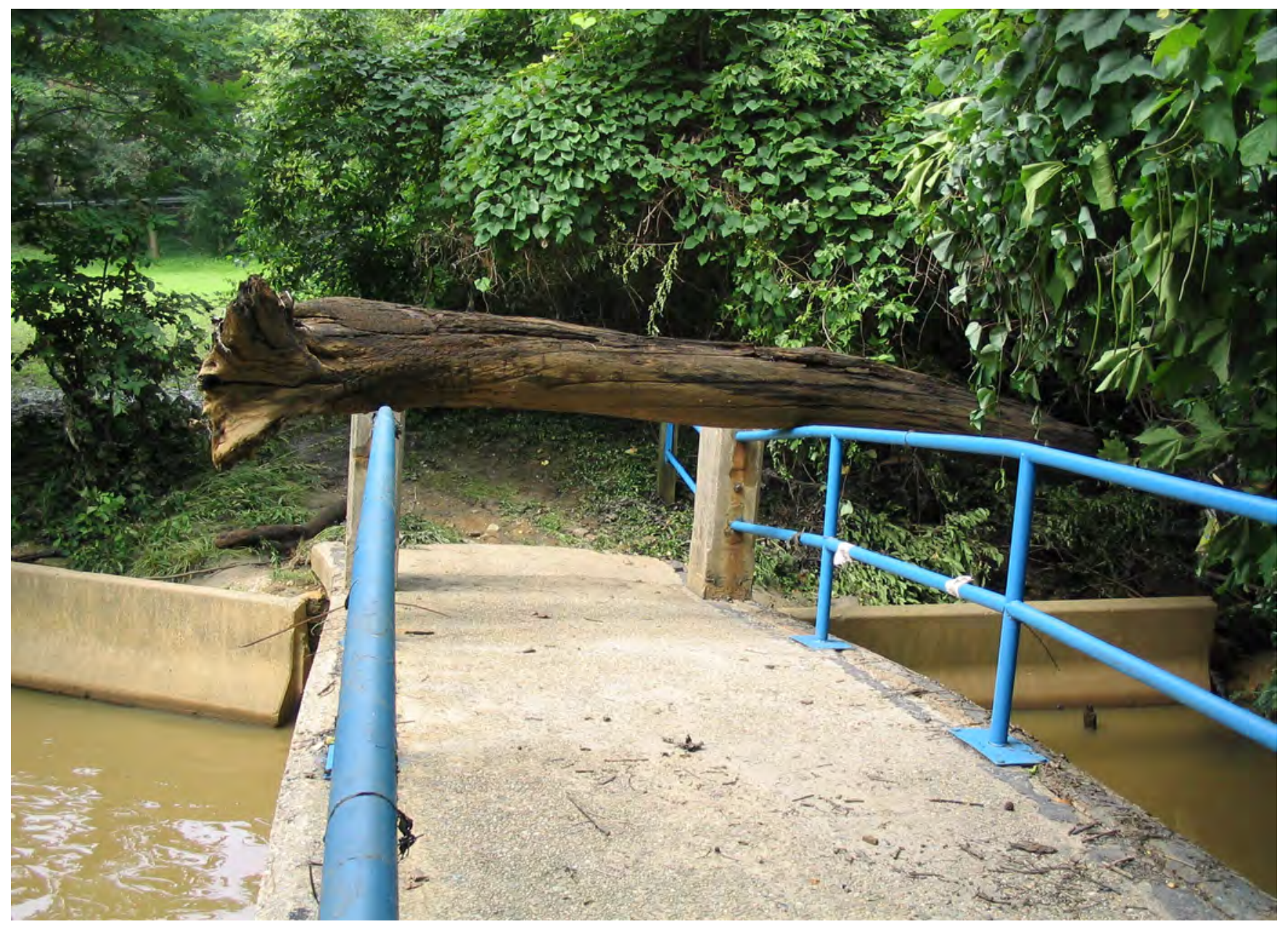

Scientific Investigations Report 2010-5151 
Cover: Receding stormwater left a large log straddling the foot bridge at the Cooper River near Haddonfield, New Jersey (photograph by Ronald J. Baker, July 14, 2004, U.S. Geological Survey) 


\section{Relation of Water Quality to Land Use in the Drainage Basins of Six Tributaries to the Lower Delaware River, New Jersey, 2002-07}

By Ronald J. Baker and Rachel A. Esralew

Prepared in cooperation with the

New Jersey Department of Environmental Protection

Scientific Investigations Report 2010-5151 


\title{
U.S. Department of the Interior \\ KEN SALAZAR, Secretary \\ U.S. Geological Survey \\ Marcia K. McNutt, Director
}

\section{U.S. Geological Survey, Reston, Virginia: 2010}

\author{
For more information on the USGS — the Federal source for science about the Earth, its natural and living resources, \\ natural hazards, and the environment, visit http://www.usgs.gov or call 1-888-ASK-USGS \\ For an overview of USGS information products, including maps, imagery, and publications, \\ visit http://www.usgs.gov/pubprod \\ To order this and other USGS information products, visit http://store.usgs.gov
}

\begin{abstract}
Any use of trade, product, or firm names is for descriptive purposes only and does not imply endorsement by the U.S. Government.

Although this report is in the public domain, permission must be secured from the individual copyright owners to reproduce any copyrighted materials contained within this report.
\end{abstract}

Suggested citation:

Baker, R.J., and Esralew, R.A., 2010, Relation of water quality to land use in the drainage basins of six tributaries to the lower Delaware River, New Jersey, 2002-07: U.S. Geological Survey Scientific Investigations Report 2010-5151, $68 \mathrm{p}$. 


\section{Contents}

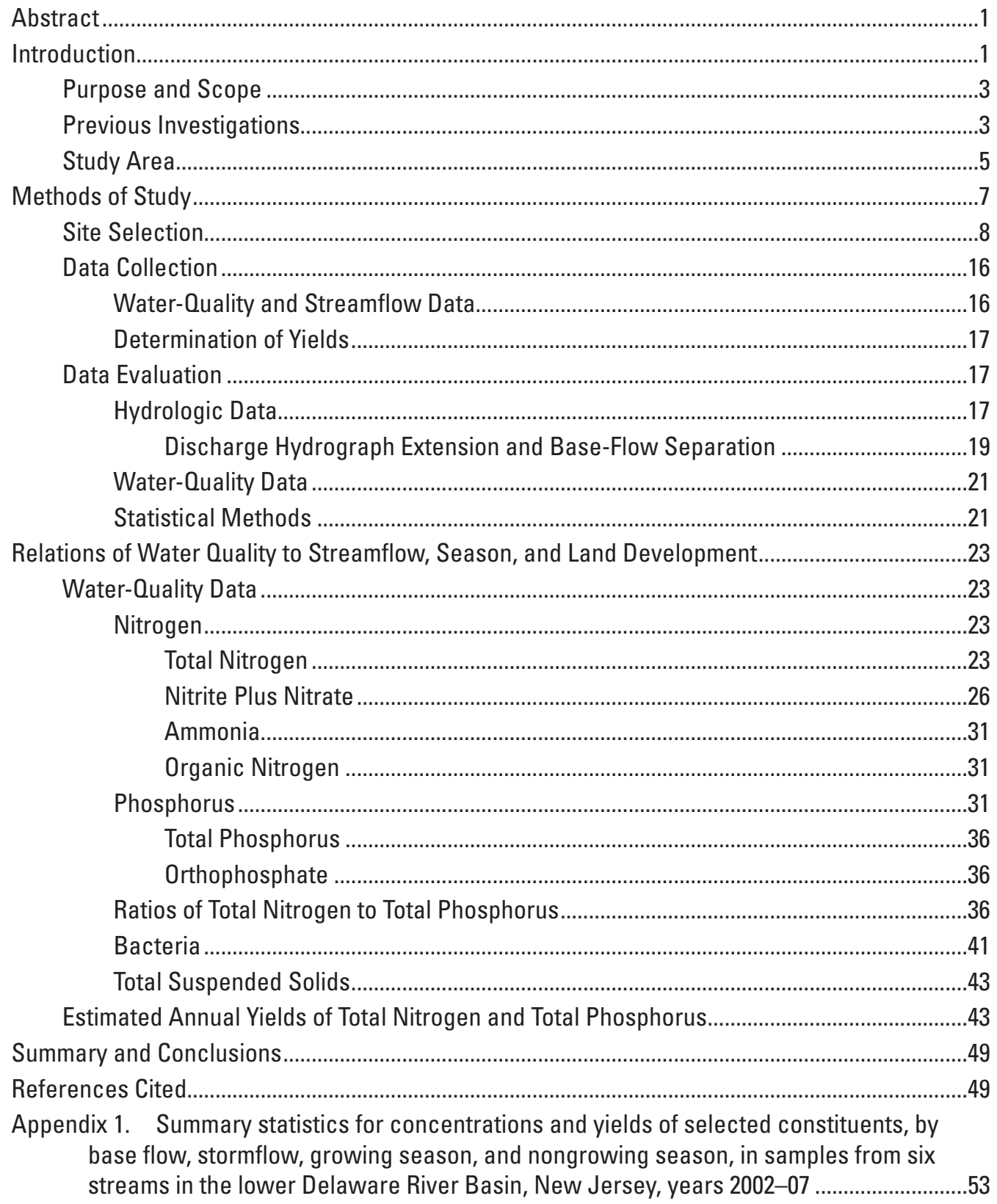




\section{Figures}

1-8. Maps showing-

1. Delaware Bay and the upper, middle, and lower zones of the lower Delaware River

2. Locations of water-quality monitoring sites and subbasins in the lower Delaware River Basin Watershed in New Jersey . . .6

3. Land use in site AGR1 drainage basin, lower Delaware River Basin in New Jersey.

4. Land use in site AGR2 drainage basin, lower Delaware River Basin in New Jersey

5. Land use in site UND1 drainage basin, lower Delaware River Basin in New Jersey.

6. Land use in site UND2 drainage basin, lower Delaware River basin in New Jersey.

7. Land use in site URB1 drainage basin, lower Delaware River watershed in New Jersey.

8. Land use in site URB2 drainage basin, lower Delaware River Basin in New Jersey.

9-10. Graphs showing-

9. Example of a rating curve used for determining streamflow from measured stream stage for site UND2, Gravelly Run at Laurel Lake, New Jersey

10. Example of a stream-stage hydrograph which includes automatic and manual stream-stage measuements for URB2, South Branch Big Timber Creek Tributary at Grenloch, New Jersey, October 17-18, 2006.

11-26. Boxplots showing-

11. Distributions of total nitrogen concentrations in unfiltered water samples collected during base flow and stormflow in the growing and nongrowing seasons at monitoring sites in the lower Delaware River Basin, New Jersey, 2002-06.

12. Distributions of area-normalized loads (yields) of total nitrogen in unfiltered water samples collected during base flow and stormflow in the growing and nongrowing seasons at monitoring sites in the lower Delaware River Basin, New Jersey, 2002-06.

13. Distributions of nitrate concentrations in unfiltered water samples collected during base flow and stormflow in the growing and nongrowing seasons at monitoring sites in the lower Delaware River Basin, New Jersey, 2002-06

14. Distributions of area-normalized loads (yields) of nitrate in unfiltered water samples collected during base flow and stormflow in the growing and nongrowing seasons at monitoring sites in the lower Delaware River Basin, New Jersey, 2002-06.

15. Distributions of ammonia concentrations in unfiltered water samples collected during base flow and stormflow in the growing and nongrowing seasons at monitoring sites in the lower Delaware River Basin, New Jersey, 2002-06.

16. Distributions of area-normalized loads (yields) of ammonia in unfiltered water samples collected during base flow and stormflow in the growing and nongrowing seasons at monitoring sites in the lower Delaware River Basin, New Jersey, 2002-06. 
17. Distributions of organic nitrogen concentrations in unfiltered water samples collected during base flow and stormflow in the growing and nongrowing seasons at monitoring sites in the lower Delaware River Basin,

New Jersey, 2002-06.

18. Distributions of area-normalized loads (yields) of organic nitrogen in unfiltered water samples collected during base flow and stormflow in the growing and nongrowing seasons at monitoring sites in the lower

Delaware River Basin, New Jersey, 2002-06.

19. Distributions of total phosphorus concentrations in unfiltered water samples collected during base flow and stormflow in the growing and nongrowing seasons at monitoring sites in the lower Delaware River Basin, New Jersey, 2002-06.

20. Distributions of area-normalized loads (yields) of total phosphorus in unfiltered water samples collected during base flow and stormflow in the growing and nongrowing seasons at monitoring sites in the lower Delaware River Basin, New Jersey, 2002-06.

21. Distributions of orthophosphate concentrations in unfiltered water samples collected during base flow and stormflow in the growing and nongrowing seasons at monitoring sites in the lower Delaware River Basin, New Jersey, 2002-06.

22. Distributions of area-normalized loads (yields) of orthophosphate in unfiltered water samples collected during base flow and stormflow in the growing and nongrowing seasons at monitoring sites in the lower Delaware River Basin, New Jersey, 2002-06.

23. Distributions of fecal coliform bacteria concentrations in unfiltered water samples collected during base flow and stormflow in the growing and nongrowing seasons at monitoring sites in the lower Delaware River Basin, New Jersey, 2002-06.

24. Distributions of area-normalized loads (yields) of fecal coliform bacteria in unfiltered water samples collected during base flow and stormflow in the growing and nongrowing seasons at monitoring sites in the lower Delaware River Basin, New Jersey, 2002-06.

25. Distributions of total suspended solids concentrations in unfiltered water samples collected during base flow and stormflow in the growing and nongrowing seasons at monitoring sites in the lower Delaware River Basin, New Jersey, 2002-06.

26. Distributions of area-normalized loads (yields) of total suspended solids in unfiltered water samples collected during base flow and stormflow in the growing and nongrowing seasons at monitoring sites in the lower Delaware River Basin, New Jersey, 2002-06...

27. Graph showing yields of phosphorus and nitrogen nutrient species in six streams in the lower Delaware River Basin, New Jersey, 2002. 


\section{Tables}

1. Mean annual values of total phosphorus, total nitrogen, chlorophyll-a, and water clarity as determined with using a Secchi disk for five trophic states.

2. Locations of six sites in the lower Delaware River Basin, New Jersey, at which streamflow and water quality were monitored during eight storms from 2002 to 2007

3. Area of, and land-use distribution in 2002 in, drainage basins upstream from six sites in the lower Delaware River Basin, New Jersey, at which streamflow and water quality were monitored during eight storms during 2002-07.

4. Description of monitoring events at six sites on streams in the lower Delaware River Basin, New Jersey, 2003-07.

5. Reference sites used to determine the number of days between the end of a storm and the return to stream base flow for six streams in the lower Delaware River Basin, New Jersey

6. Analytical methods used for surface-water samples

7. Results of statistical tests to determine whether constituent concentrations and yields differ among sites during growing and nongrowing seasons, lower Delaware River Basin, New Jersey.....

8. Mean percentages of total nitrogen in unfiltered water samples represented by four nitrogen species for six streams in the lower Delaware River Basin, New Jersey.

9. Ratios of nitrogen to phosphorus in six tributaries to the Delaware River, New Jersey, 2003-07

10. Annual loads of selected water-quality characteristics for three streams in the lower Delaware River Basin, New Jersey 


\section{Conversion Factors}

Inch/Pound to SI

\begin{tabular}{lcl}
\hline Multiply & By & To obtain \\
\hline & Length & \\
\hline inch (in.) & 2.54 & centimeter $(\mathrm{cm})$ \\
inch (in.) & 25.4 & millimeter $(\mathrm{mm})$ \\
foot (ft) & 0.3048 & meter $(\mathrm{m})$ \\
mile (mi) & 1.609 & kilometer $(\mathrm{km})$ \\
\hline & Area & \\
\hline square mile $\left(\mathrm{mi}^{2}\right)$ & 2.590 & square $\mathrm{kilometer}\left(\mathrm{km}^{2}\right)$ \\
\hline & Flow rate & \\
\hline foot per second $(\mathrm{ft} / \mathrm{s})$ & 0.3048 & meter per second $(\mathrm{m} / \mathrm{s})$ \\
cubic foot per second $\left(\mathrm{ft}^{3} / \mathrm{s}\right)$ & 0.02832 & cubic meter per second $\left(\mathrm{m}^{3} / \mathrm{s}\right)$ \\
\hline
\end{tabular}

Temperature in degrees Celsius $\left({ }^{\circ} \mathrm{C}\right)$ may be converted to degrees Fahrenheit $\left({ }^{\circ} \mathrm{F}\right)$ as follows:

$$
{ }^{\circ} \mathrm{F}=\left(1.8 x^{\circ} \mathrm{C}\right)+32
$$

Temperature in degrees Fahrenheit $\left({ }^{\circ} \mathrm{F}\right)$ may be converted to degrees Celsius $\left({ }^{\circ} \mathrm{C}\right)$ as follows:

$$
{ }^{\circ} \mathrm{C}=\left({ }^{\circ} \mathrm{F}-32\right) / 1.8
$$

Specific conductance is given in microsiemens per centimeter at 25 degrees Celsius $\left(\mu \mathrm{S} / \mathrm{cm}\right.$ at $\left.25^{\circ} \mathrm{C}\right)$.

Concentrations of chemical constituents in water are given either in milligrams per liter (mg/L) or micrograms per liter $(\mu \mathrm{g} / \mathrm{L})$. 



\title{
Relation of Water Quality to Land Use in the Drainage Basins of Six Tributaries to the Lower Delaware River, New Jersey, 2002-07
}

\author{
By Ronald J. Baker and Rachel A. Esralew
}

\section{Abstract}

Concentrations and loads of water-quality constituents in six streams in the lower Delaware River Basin of New Jersey were determined in a multi-year study conducted by the U.S. Geological Survey, in cooperation with the New Jersey Department of Environmental Protection. Two streams receive water from relatively undeveloped basins, two from largely agricultural basins, and two from heavily urbanized basins. Each stream was monitored during eight storms and at least eight times during base flow during 2002-07. Sampling was conducted during base flow before each storm, when stage was first observed to rise, and several times during the rising limb of the hydrographs. Agricultural and urban land use has resulted in statistically significant increases in loads of nitrogen and phosphorus species relative to loads in undeveloped basins. For example, during the growing season, median storm flow concentrations of total nitrogen in the two streams in agricultural areas were 6,290 and 1,760 mg/L, compared to 988 and $823 \mathrm{mg} / \mathrm{L}$ for streams in urban areas, and 719 and $333 \mathrm{mg} / \mathrm{L}$ in undeveloped areas. Although nutrient concentrations and loads were clearly related to land useurban, agricultural, and undeveloped-within the drainage basins, other basin characteristics were found to be important. Residual nutrients entrapped in lake sediments from streams that received effluent from recently removed sewage-treatment plants are hypothesized to be the cause of extremely high levels of nutrient loads to one urban stream, whereas another urban stream with similar land-use percentages (but without the legacy of sewage-treatment plants) had much lower levels of nutrients. One of the two agricultural streams studied had higher nutrient loads than the other, especially for total phosphorous and organic nitrogen. This difference appears to be related to the presence (or absence) of livestock (cattle).

\section{Introduction}

The ecologically significant effect of excess nutrients in a water body is eutrophication, which stimulates an array of changes. These changes can include increased phytoplankton and rooted aquatic plant (macrophyte) production, deterioration of fish habitat and water quality, a decrease in biodiversity, and other undesirable changes that interfere with water uses (Bartsch, 1972). Biodiversity tends to decrease with increasing eutrophication (Weckström and others, 2007). The trophic state of a water body can be characterized by the concentration of phosphorus, nitrogen, chlorophyll a, and dissolved oxygen and by water clarity as determined by a Secchi disk or other means. The ranges of those nutrient and chlorophyll-a concentrations and water-clarity levels that correspond to various trophic states are listed in table 1.

Naturally occurring eutrophication is the natural aging process of a water body and the subsequent effects on water quality and biological structure and function (Rast and Thornton, 1996). External or allochthonous sediment and organic matter of terrestrial origin accumulate in a lake basin, gradually decreasing the depth of the water body and allowing autochthonous biologic production to increase to the point that the lake begins to take on a marsh-like character and, ultimately, a terrestrial character. The same progression occurs in wide, slow-flowing reaches of streams, resulting in the filling of the stream or river valley as the end point. Natural eutrophication generally occurs over geologic time, whereas anthropogenic or "cultural" eutrophication can occur within a decade.

Although the lower reaches of the Delaware River are not substantially eutrophic, the middle and upper reaches have high nutrient and chlorophyll a concentrations and moderately low dissolved oxygen concentrations (Delaware Inland Bays Estuary Program, 1993). Contributions of organic, inorganic, and microbial contaminants from the lower Delaware River Basin can have adverse effects on the ecological, commercial, and recreational value of the estuary and the Delaware Bay. The Delaware Estuary receives some of the largest loads of 
Table 1. Mean annual values of total phosphorus, total nitrogen, chlorophyll-a, and water clarity as determined with using a Secchi disk for five trophic states.

$[\mu \mathrm{g} / \mathrm{L}$, micrograms per liter; $\mathrm{m}$, meter; <, less than; >, greater than]

\begin{tabular}{lcccc}
\hline \multicolumn{1}{c}{ Trophic state } & $\begin{array}{c}\text { Total } \\
\text { phosphorus } \\
(\boldsymbol{\mu g} / \mathbf{L})\end{array}$ & $\begin{array}{c}\text { Total } \\
\text { nitrogen } \\
(\mathbf{\mu g} / \mathbf{L})\end{array}$ & $\begin{array}{c}\text { Chlorophyll a } \\
(\boldsymbol{\mu g} / \mathbf{L})\end{array}$ & $\begin{array}{c}\text { Secchi disk } \\
\mathbf{d e p t h} \\
(\mathbf{m})\end{array}$ \\
\hline Ultra-oligotrophic & $<4$ & $<250$ & $<1$ & $>12$ \\
Oligotrophic & $4-10$ & $250-500$ & $1-2.5$ & $6-12$ \\
Mesotrophic & $10-35$ & $500-1,000$ & $2.5-8$ & $3-6$ \\
Eutrophic & $35-100$ & $1,000-2,000$ & $8-25$ & $1.5-3$ \\
Hypertrophic & $>100$ & $>2,000$ & $>25$ & $<1.5$ \\
\hline
\end{tabular}

nitrogen and phosphorus nutrients in the world (Sutton and others, 1996).

Substantial nutrient loading can contribute to toxic or nuisance algal blooms and degrade estuarine water quality (Granéli and Turner, 2006; Wassmann and Olli, 2004). Phytoplankton production (often quantified by the measurement of chlorophyll a) can reduce light penetration and deplete dissolved oxygen concentrations, which can in turn degrade submerged aquatic vegetation and associated habitat functions (Kennish, 1997).

Point sources such as domestic wastewater-treatmentplant discharges and industrial-waste discharge comprise about two-thirds of the total nutrient load to the Delaware Bay (Delaware Inland Bays Estuary Program, 1993). The remaining third consists of non-point sources (NPSs) such as leaking septic systems, farmlands, lawns, and atmospheric deposition. The quantity of storm runoff is affected by the amount of impervious surface in the drainage basin, which in turn is a function of the amount of development (including residential, commercial, and industrial land use), as has been demonstrated in a study by Whiley and others (2009).

Since the early 1960s, point-source discharges have been the main focus of Federal and State water-quality efforts in the Delaware River Basin (Greeley-Polhemus Group, Inc., 1990). Since the implementation of these water-contamination control policies, levels of dissolved oxygen have increased, whereas concentrations of fecal coliform bacteria and nutrients have decreased in the Delaware River Estuary and Delaware Bay (Delaware River Basin Commission, 1994). NPSs did not receive significant attention until the implementation of the Federal Clean Water Act, Section 208, in 1970, which includes increased land-use regulations and encourages best-management practices (BMP) for reducing loads of contaminants, such as nitrogen and phosphorus, to streams from nonpoint sources. BMPs are practices that are determined by the State to be practical and effective in achieving and maintaining NPS loads at levels compatible with water-quality goals and may include stormwater management, headwater protection practices, or zoning restrictions on development (Lynch and Corbett, 1990).

In 2004, a provision was added to the Clean Water Act to help identify BMPs that will result in water bodies meeting Federal water-quality standards (U.S. Environmental Protection Agency, 2004). This provision, Section 303(d), calls for the establishment of total maximum daily loads (TMDLs) of contaminants from point and nonpoint sources to water bodies that do not currently meet these standards after the implementation of technology-based effluent limitations. TMDLs for water bodies in New Jersey are developed by the New Jersey Department of Environmental Protection (NJDEP) as a mechanism for reducing nutrient contaminant loads. Allocations of contaminant loads can be assigned to the sources contributing the loads in order to control and reduce the environmental degradation of a water body. Because nonpoint source loads do not come from discrete, identifiable sources, the assignment of load allocations would impart load reductions to activities that contribute nonpoint-source loads; the reductions are implemented through BMPs (Lehr and others, 2005).

NJDEP has initiated a watershed-based approach to water-quality management in order to develop TMDLs for water bodies throughout the State (New Jersey Department of Environmental Protection, 2009). NJDEP has designated 20 watershed management areas within four watershed regions delineated by hydrogeologic boundaries. As part of NPS and stormwater-management strategies for the New Jersey portion of the lower Delaware River Basin, the NJDEP, U.S. Environmental Protection Agency (USEPA) Region 2, the Delaware River Basin Commission (DRBC), and other local New Jersey agencies have begun to implement BMPs in watersheds within the lower Delaware River Basin (Delaware River Basin Commission, 1994).

As of 2009, within the lower Delaware River Basin, TMDLs for total phosphorus have been proposed for 15 lakes and 13 tributary stream segments. Additionally, TMDLs for fecal coliform loads have been proposed for 36 basins, and 17 lakes have TMDLs for pathogens. Six TMDLs were 
established by the NJDEP in 2004 for four stream segments and two impoundments along the length of the Cooper River, one of the streams studied in this investigation. Phosphorus, largely from runoff, was found to be present in unacceptably high concentrations for the intended ecological, consumptive, and recreational use of the Cooper River. BMPs were presented in the TMDL document. In order to achieve TMDL goals, phosphorus loads from the Cooper River Basin would have to be reduced by about 85 percent.

In order to establish TMDLs and implement BMPs to improve water quality for other streams within the lower Delaware River Basin, a better understanding of relations between land-use practices and non-point contaminant loading is needed. According to 1995-1997 land-use analysis (Lathrop, 2000), approximately 25 percent of the lower Delaware River Basin is considered urban, 25 percent is agricultural land, and 50 percent is forested or wetland areas. From 1986 to 2000 impervious surface coverage increased in the basin as a result of an increase in urban development (Lathrop, 2000; Hasse and Lathrop, 2001) when agricultural land (farmland) was converted to urban use (Lathrop, 2000).

From 2003 to 2007 the U.S. Geological Survey (USGS), in cooperation with the NJDEP, conducted a study to determine the relation between land use and water quality in several tributaries to the Lower Delaware River (fig. 1). The objectives of this study were to (1) identify several basins of the lower Delaware River Basin that have different land-use patterns and select appropriate streamgaging and water-quality sampling locations; (2) collect hydrological and water-quality data from each sampling location during base flow and stormflow over several years; (3) calculate streamflow and determine concentrations of water-quality constituents, then determine the loads of each constituent for each sampling event, and (4) relate water-quality characteristics to land use, seasonality (growing and nongrowing), and hydrologic condition (base flow or stormflow). To this end, streamflow and loads of nitrogen and phosphorus species were measured in six streams in the lower Delaware River Basin during base-flow and stormflow conditions. Seasonal effects (growing and nongrowing seasons) on water quality and loading were considered. The water-quality constituents studied are total nitrogen, ammonia, nitrate plus nitrite, organic nitrogen, total phosphorus, orthophosphate, total organic carbon, total suspended solids, and fecal coliform and Escherichia coli bacteria. The scope of this investigation was constrained by the freshwater riverine system, and although the ultimate delivery of nutrients to the Delaware Bay estuary and beyond is of great environmental interest, that topic is beyond the scope of this study.

\section{Purpose and Scope}

This report presents the concentrations and estimated yields (area-normalized loads) of nutrients, bacteria, and suspended solids in six tributaries to the Lower Delaware River used to evaluate the relation between land use and water quality in the six basins. Annual loads of phosphorus and nitrogen species also are presented. The constituent concentration and yield values presented in this report are based on water-quality and streamflow data collected during base-flow and stormflow conditions and during growing and nongrowing seasons from 2003 to 2007 . Graphical presentations are used to show how constituent concentrations and yields vary during base flow and stormflow in the growing and nongrowing seasons. A numerical model relating water quality and constituent loads to percentages of land development is described. The principal objectives of this report are to document nutrient concentrations and loads in these six tributaries to the Delaware River and to show the relation between land use and water quality.

\section{Previous Investigations}

The USGS, in cooperation with State and local agencies, has been conducting comprehensive water-quality studies in New Jersey since the early 1960s. Many of these studies have attempted to relate NPS contributions from agricultural areas to groundwater quality, although a few have investigated NPS contributions from urban and agricultural land to the quality of surface water. Generally, these few studies have demonstrated that the highest levels of nutrient loads in streams result from agricultural land use, although urban land use also is associated with elevated nutrient loads. The lowest levels of nutrient loads were found to occur in undeveloped areas and basins.

Three USGS NPS studies were conducted in the Coastal Plain of New Jersey. A fourth USGS study was conducted in a basin of the Lower Delaware River in Pennsylvania and Delaware. The Coastal Plain NPS studies were conducted in the Mill Creek Basin in Willingboro, Burlington County (Schornick and Fishel, 1980); in the Great Egg Harbor River Basin in Winslow Township, Camden County (Fusillo, 1981); and in the Toms River Basin in Ocean County (Hunchak-Kariouk and others, 1999; Baker and Hunchak-Kariouk, 2006). In Pennsylvania and Delaware, a model for the Christina River Basin, which drains to the Lower Delaware River, was constructed. The model included sites in both the Piedmont and Coastal Plain Physiographic Province areas of the basin (Senior and Koerkle, 2003). A comprehensive study of water quality in the Delaware River Basin was completed by Fischer and others (2004). This study included nutrients as well as pesticides, volatile organic compounds, trace elements, and other contaminants.

Schornick and Fishel (1980) report that runoff from the upstream, nonresidential part of the Mill Creek drainage basin had a more substantial effect on the quality of surface water than did runoff from the downstream residential part of the basin. Land use in nonresidential areas was predominantly agricultural with minor amounts of undeveloped and residential areas, according to the 1970s land-use survey (Lathrop, 2000). Higher concentrations and loads of nutrients in upstream stormwater runoff than in downstream runoff appear 


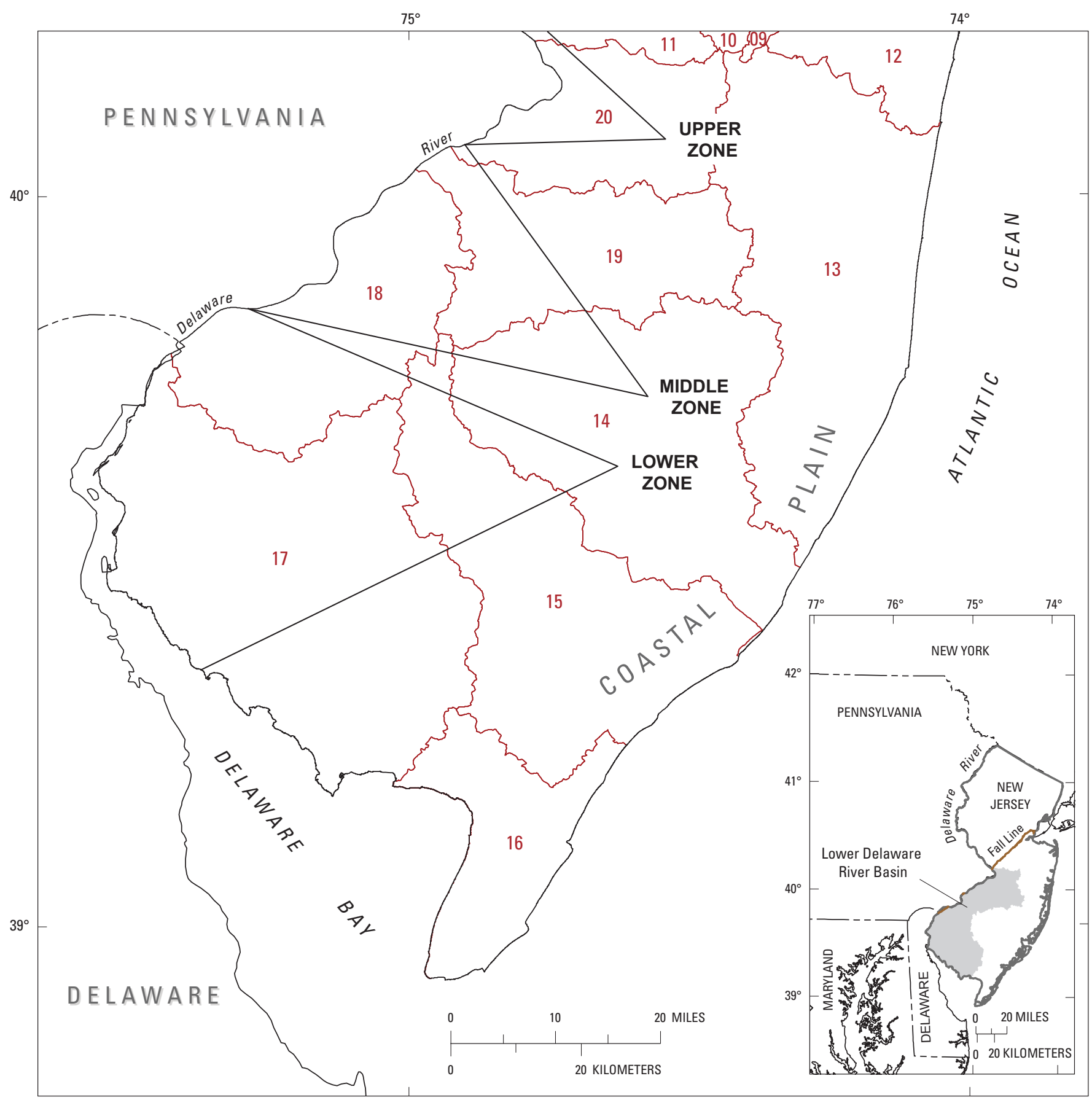

Base from U.S. Geological Survey digital

line graph files, 1:24,000

Figure 1. Delaware Bay and the upper, middle, and lower zones of the lower Delaware River. [Numbers indicate New Jersey Watershed Management Areas]

to be the result of agricultural activity. These loads from agricultural areas affected the water quality more than loads from residential development in the downstream part of the basin.

Fusillo (1981) reports that samples collected from surface-water monitoring sites on the Great Egg Harbor River in urban areas of Winslow Township, Camden County, New Jersey, had higher values for specific conductance, chloride, nitrate, and phosphorus than did samples from monitoring sites in less developed areas. Water samples collected downstream from a domestic wastewater-treatment plant has substantially higher concentrations of nutrients than those collected upstream from the plant. A new residential development has the effect of slightly increasing nutrient concentrations. 
Baker and Hunchak-Kariouk (2006) studied NPS contributions during stormflow and base flow in several basins in Ocean County, New Jersey, that had varying levels of development. Baker and Hunchak-Kariouk report that during stormflow, sites with the highest percentage of developed land yielded higher concentrations of ammonia, fecal coliform, suspended sediment, and phosphate, whereas sites with moderate development yielded higher concentrations of other nitrogen and phosphorus species. They also report no significant relations between groundwater contributions of nutrients (estimated by measuring concentrations during base flow) and land use, and hypothesize that the loads of these constituents could be affected by other basin characteristics, such as hydrogeology and previous land-use practices.

A regional water-quality survey of the Delaware River Basin was made by Fischer and others (2004). Total nitrogen and phosphorus concentrations were found to be greater in streams with the drainage basins that have high percentages of urban or agricultural land use. Nitrate was the predominant form of nitrogen and was detected in 95 percent of the streams sampled. The highest concentration measured was $10.5 \mathrm{mg} / \mathrm{L}$ as $\mathrm{N}$, and the median concentration was $0.87 \mathrm{mg} / \mathrm{L}$ as N. Organic nitrogen typically constituted about 20 percent of the total nitrogen detected. Total phosphorus concentrations exceeded $0.1 \mathrm{mg} / \mathrm{L}$ as $\mathrm{P}$, a goal established by USEPA for minimizing nuisance plant growth, in more than 50 percent of samples collected from some sites. Phosphorus concentrations tended to be higher in stormwater samples than in base-flow samples.

A study of the relation between agricultural land use and nutrient concentrations and loads in the Coastal Plain basins of the Chesapeake Bay (Jordan and others, 2003) showed that mean concentrations of nitrogen species increased as the percentage of cropland in the basin increased. Phosphorus species, however, were more strongly correlated with concentrations of particulate matter than with land-use practices, and the nitrogen-to-phosphorus ratio varied substantially among the basins studied. A significant relation was identified between discharges of nitrogen from the basins and the input of anthropogenically derived nitrogen into the basin from all sources, including atmospheric deposition, fertilizers, and nitrogenfixing crop plants.

The effects of land-use change on nutrient discharge from the Patuxent River watershed in Pennsylvania were investigated by Jordan and others (2003). Linear models were constructed to relate concentrations of nutrients, sediment, and other constituents to nonpoint and point sources of discharges in the watershed. It was found that conversion from undeveloped land to cropland uses had the most substantial effect on water quality, conversion from cropland to urban development had less effect, and conversion from undeveloped land to urban development had the least effect. The model was used to predict changes in the discharge of nutrients and other constituents from the basins through the year 2020 on the basis of current patterns of population growth.

\section{Study Area}

The tidal part of the Delaware River in southwestern New Jersey and southeastern Pennsylvania extends from just below Trenton, New Jersey, to the mouth of the Delaware Bay. The lower Delaware River Basin is estuarine in nature (Sutton and others, 1996). It covers 5,900 square miles and accounts for 47 percent of the total drainage area of the entire Delaware River Basin (Velnich, 1982).

The Lower Delaware River Region is one of five water regions, as defined by the NJDEP (Watt, 2000). It comprises four watershed management areas (numbers 17-20) and occupies the area from just north of Trenton, New Jersey, to the mouth of the Delaware Bay. The lower Delaware River Basin lies entirely within the Coastal Plain Physiographic Province, and all streams and tributaries drain to the Delaware River or Delaware Bay. The Coastal Plain is characterized by flat topography and unconsolidated sediment (alternating layers of clay, silt, sand, and gravel). The sediment wedge decreases in thickness from south to north; the wedge is $6,500 \mathrm{ft}$ thick at southern tip of the State and absent at the Fall Line. All Coastal Plain aquifers but one are confined, except at outcrop areas. The Kirkwood-Cohansey aquifer system is mostly unconfined.

Development of forested and agricultural land has increased since the early 1970 s and is expected to continue to increase (New Jersey Department of Environmental Protection and Energy, 1993; Hasse and Lathrop, 2008). Although the lower Delaware River Basin remains in large part agricultural, land-use and land-cover digital data indicate that residential and commercial plus industrial land uses have increased substantially over the last 30 years (U.S. Geological Survey, 1986; Hasse and Lathrop, 2008). As of 1997, urban land use accounted for 25 percent of the lower Delaware River Basin.

Water quality and streamflow were measured in six tributaries to the Delaware River (Blacks Creek, Lahaway Creek, Cooper River, South Branch Big Timber Creek, Alloway Creek, and Gravelley Run) (fig. 2). Two streams were selected for each of three predominant land-use types (agricultural, undeveloped, and urban). A single monitoring site was established on each stream. Locations of the six sites are given in table 2, and a summary of the land-use percentages in the basins draining into each stream, upstream from each monitoring site, are given in table 3 . There are no known point sources within these basins. 


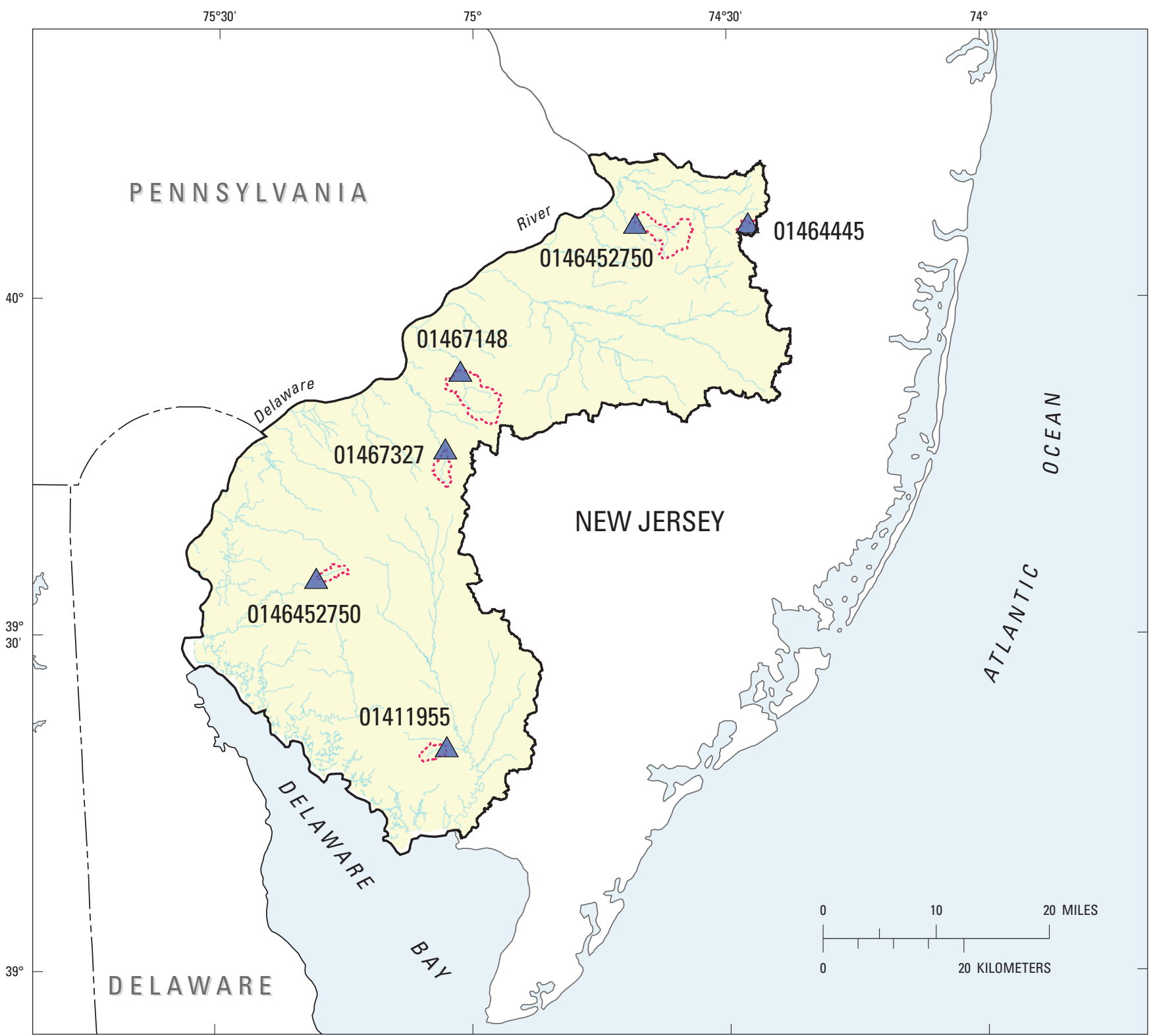

Base from U.S. Geological Survey digital line graph files, 1:24,000

EXPLANATION

\section{— Lower Delaware Region boundary \\ - - - - Subbasin boundary}

01467327 Monitoring site and U.S. Geological Survey (USGS) identification number (ID)

\begin{tabular}{|l|l|}
\hline USGS site ID & \multicolumn{1}{c|}{ Site name } \\
\hline 01467327 & South Branch Big Timber Creek at Grenloch \\
\hline 0146452750 & Blacks Creek near Chesterfield \\
\hline 01467148 & Cooper River at Route 561 at Haddonfield \\
\hline 01464445 & Lahaway Creek near Prospertown \\
\hline 01411955 & Gravelly Run at Laurel Lake \\
\hline 01482890 & Alloway Creek near Watson's Corner \\
\hline
\end{tabular}

Figure 2. Locations of water-quality monitoring sites and subbasins in the lower Delaware River Basin Watershed in New Jersey. 
Table 2. Locations of six sites in the lower Delaware River Basin, New Jersey, at which streamflow and water quality were monitored during eight storms from 2002 to 2007.

[USGS, U.S. Geological Survey; WMA, watershed management area]

\begin{tabular}{|c|c|c|c|c|}
\hline USGS station name & $\begin{array}{c}\text { USGS } \\
\text { station } \\
\text { identifier }\end{array}$ & $\begin{array}{c}\text { USGS } \\
\text { station } \\
\text { number } \\
\text { (figure 1) }\end{array}$ & Station latitude and longitude & WMA \\
\hline Lahaway Creek Tributary near Prospertown & UND1 & 01464445 & Lat $40^{\circ} 06^{\prime} 51^{\prime \prime} ;$ Long $74^{\circ} 27^{\prime} 31^{\prime \prime}$ & 20 \\
\hline Gravelly Run at Laurel Lake & UND2 & 01411955 & Lat $39^{\circ} 20^{\prime} 14^{\prime \prime}$; Long $75^{\circ} 03^{\prime} 04^{\prime \prime}$ & 17 \\
\hline Alloway Creek near Watson Corner & AGR2 & 01482890 & Lat $39^{\circ} 35^{\prime} 13^{\prime \prime}$; Long $75^{\circ} 18^{\prime} 22^{\prime \prime}$ & 18 \\
\hline Cooper River at Route 561 at Haddonfield & URB1 & 01467148 & Lat $39^{\circ} 53^{\prime} 42^{\prime \prime}$; Long $75^{\circ} 01^{\prime} 29^{\prime \prime}$ & 19 \\
\hline South Branch Big Timber Creek Tributary at Grenloch & URB2 & 01467327 & Lat $39^{\circ} 46^{\prime} 46^{\prime \prime}$; Long $75^{\circ} 03^{\prime} 15^{\prime \prime}$ & 18 \\
\hline
\end{tabular}

Table 3. Area of, and land-use distribution in 2002 in, drainage basins upstream from six sites in the lower Delaware River Basin, New Jersey, at which streamflow and water quality were monitored during eight storms during 2002-07.

[mi², square mile; USGS, U.S. Geological Survey; station identifiers are shown in table 2]

\begin{tabular}{|c|c|c|c|c|c|c|c|c|}
\hline \multirow{2}{*}{$\begin{array}{c}\text { USGS } \\
\text { station } \\
\text { identifier }\end{array}$} & \multirow{2}{*}{$\begin{array}{c}\text { Drainage } \\
\text { area } \\
\left(\mathrm{mi}^{2}\right)\end{array}$} & \multirow{2}{*}{ Land use } & \multicolumn{6}{|c|}{ Land-use distribution (percent) } \\
\hline & & & Agricultural & Barren & Forested & Urban & Water & Wetland \\
\hline UND2 & 3.3 & Pristine & 5.8 & 0.1 & 78.8 & 0.9 & 0.0 & 14.4 \\
\hline AGR2 & 3.0 & Highly agricultural & 76.6 & 1.1 & 8.2 & 7.5 & 0.3 & 6.2 \\
\hline URB1 & 17.8 & Moderately urban & 1.3 & 1.9 & 17.0 & 69.2 & 1.0 & 9.5 \\
\hline URB2 & 4.3 & Moderately urban & 3.9 & 0.2 & 14.1 & 73.7 & 1.5 & 6.6 \\
\hline
\end{tabular}

\section{Methods of Study}

Samples for water-quality analysis were collected and streamflow was measured during the growing and nongrowing seasons during periods of base flow and stormflow from September 2003 to April 2007. At all sites, samples were collected, and water stage was measured by NJDEP personnel from the Bureau of Marine Water Monitoring (BMWM) and the Bureau of Freshwater and Biological Monitoring (BFBM). BMWM performed all laboratory analyses, and qualityassurance analyses were performed by the BFBM. Waterquality data used in this report are maintained by the NJDEP, BMWM, and are available in electronic form upon request from the NJDEP, BMWM, PO Box 405, Stony Hill Rd, Leeds
Point, NJ, 08220. USGS personnel measured stream stage and streamflow and developed stage-to-streamflow relations. Streamflow values were calculated by USGS personnel from stream-stage data and stage-discharge relations (rating curves). The dates of data collection and types of data collected at each site during each monitoring event are listed in table 4. 
Table 4. Description of monitoring events at six sites on streams in the lower Delaware River Basin, New Jersey, 2003-07.

[USGS, U.S. Geological Survey; Growing season: April 1-October 31; Non-growing season, November 1-March 31; yes, event was monitored; no, event was not monitored]

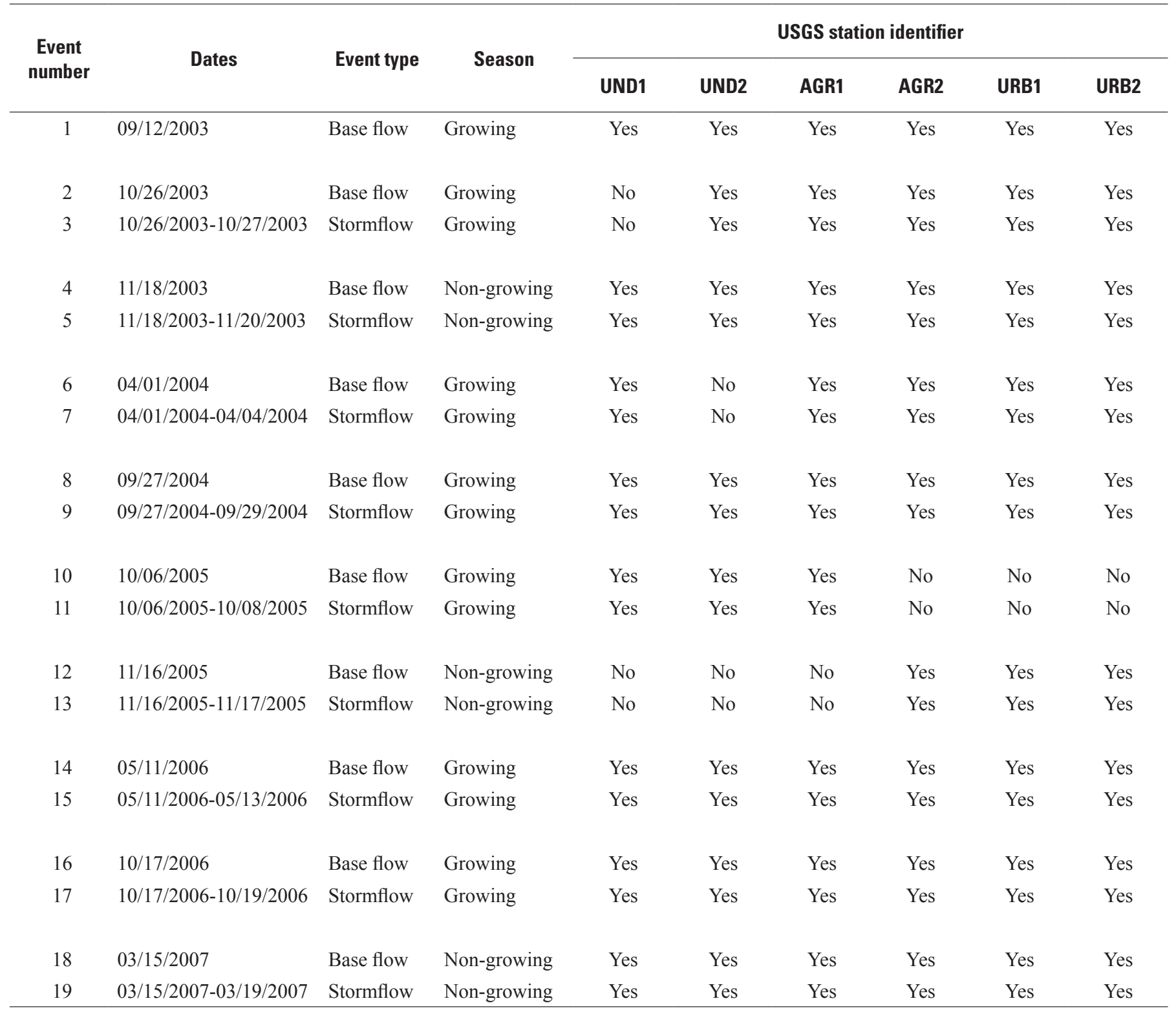

\section{Site Selection}

The sites were selected on the basis of (1) the land-use percentages in the basin, (2) the ability to establish an acceptable stream stage-to-streamflow relation (rating curve), and (3) the suitability of the site for water-quality sample collection.

To select the water-quality sampling sites, land-usedistribution data (U.S. Geological Survey, 1986; New Jersey department of Environmental Protection, 2000), recent aerial photographs, county street maps, soil surveys (Markley, 1962, 1971, 1988), and field observations were used in conjunction with a geographic information system to evaluate land use in the contributing drainage areas. For this investigation, the six level I land-use categories identified (Anderson and others, 1976) were grouped into three main categories: (1) urban, also consisting of most non-agricultural barren areas; (2) agriculture; and (3) undeveloped, consisting of forested plus wetland areas.

Few basins could be identified that had a single, predominant land use. Therefore, several sites were selected so that the contributing area had at least one land use that comprised more than 50 percent of the drainage basin, and this land use was designated as the predominant land use (table 3 ).

The monitoring site on Blacks Creek (AGR1; fig. 3) located near Chesterfield in Burlington County, New Jersey, 


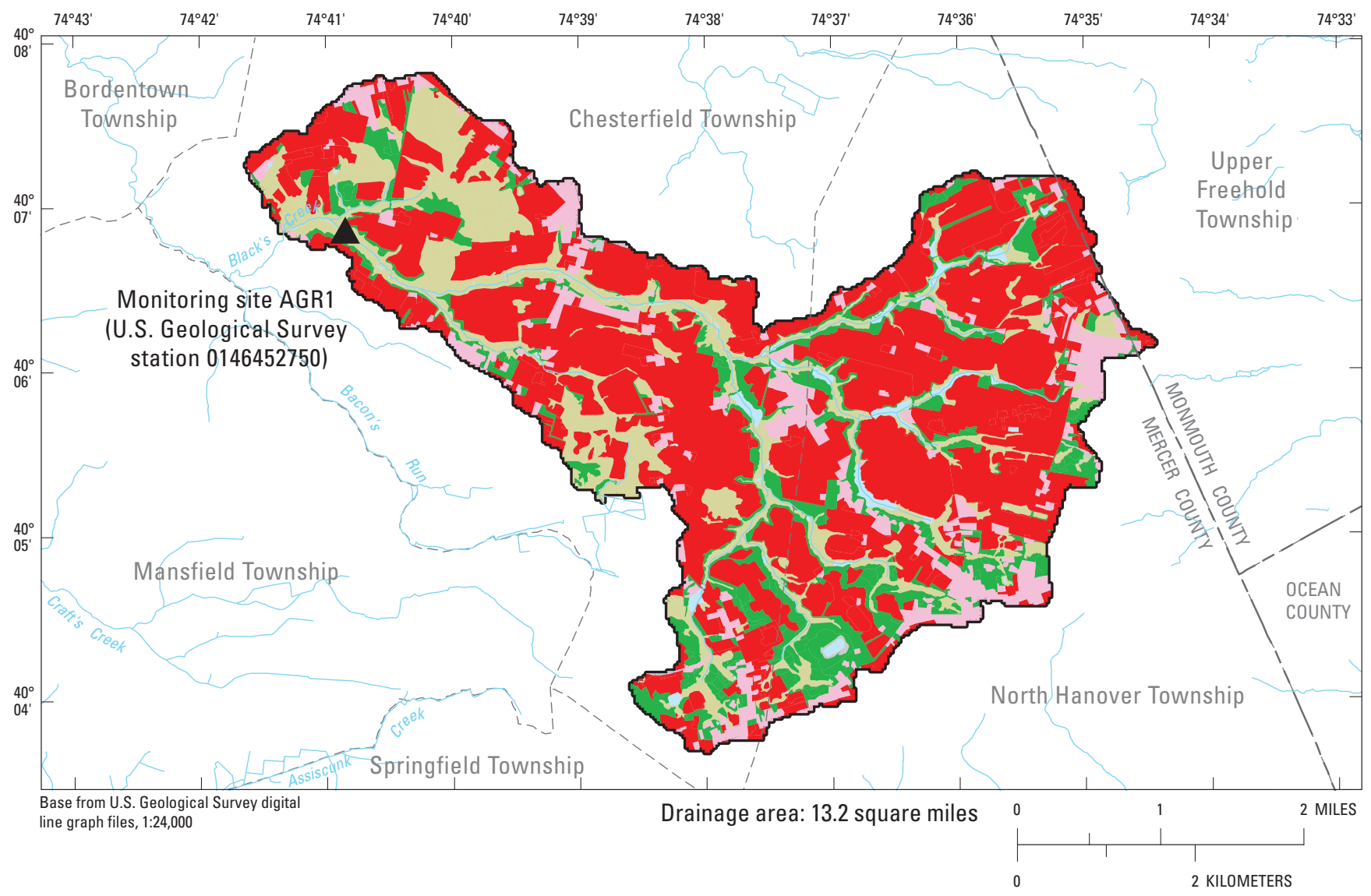

EXPLANATION

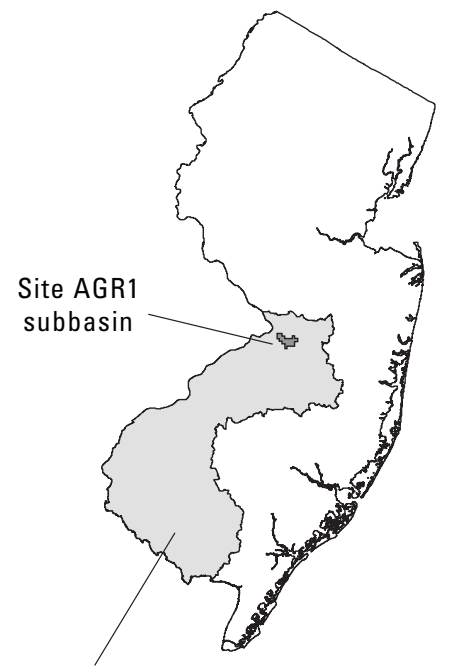

LAND USE - From N.J. Department of Environmental Protection, digital data file, 2002

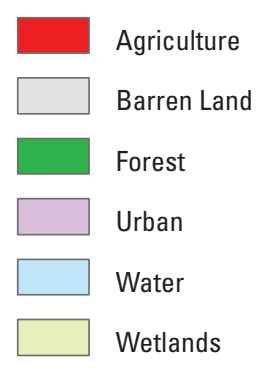

Monitoring site

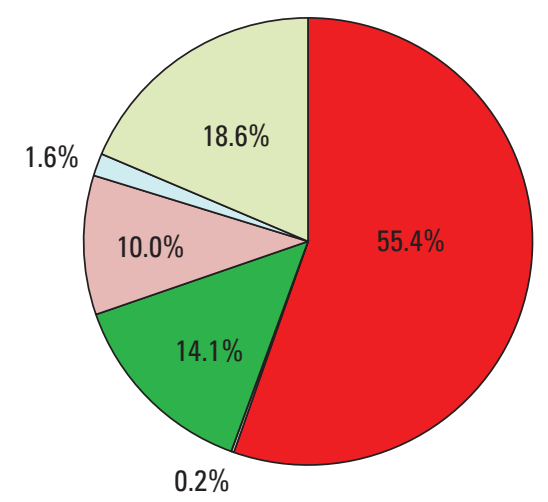

Lower Delaware

River Basin

Figure 3. Land use in site AGR1 drainage basin, lower Delaware River Basin in New Jersey. 
drains an area of $13.2 \mathrm{mi}^{2}$, and the entire stream is classified as FW $1^{1}$ using the surface-water-quality standards for New Jersey (New Jersey Department of Environmental Protection, 2008). This basin is moderately agricultural (55.4 percent) with cropland and pastureland throughout the basin and with several smaller horticultural land-use areas in the upper basin. Deciduous forest and wooded wetlands, which account for about 33 percent, are dispersed throughout the basin and create buffer areas around the streams and tributaries. The wetlands are primarily located in the lower part of the basin. Urban development (mostly rural single-unit residences) currently (2007) comprises about 10 percent of the basin area. During 1986-97, urban development increased by more than 50 percent, about 85 percent of which was converted from agricultural land use. Urban development continues to increase while forest, wetland, and agricultural areas decrease (U.S. Geological Survey, 1986).

The monitoring site on Alloway Creek (AGR2; fig. 4), located near Watson's Corner in Salem County, New Jersey, receives water that drains an area of $3.0 \mathrm{mi}^{2}$. The entire stream is designated as FW2/SE1 ${ }^{1}$ (New Jersey Department of Environmental Protection, 2008), although the location of the monitoring site is in freshwater. This basin is highly agricultural (76.6 percent) and includes mostly cropland and pastureland with a small confined feeding lot near the basin outlet and several smaller horticultural land-use areas in the upper part of the basin. Urban development in this basin, which is mostly residential, is minimal (about 7.5 percent).

The monitoring site on Prospertown Brook, which is a tributary to the Lahaway Creek (UND1; fig. 5), is located in Plumsted and Jackson Townships, Ocean County, New Jersey; the site receives water from an area of $2.3 \mathrm{mi}^{2}$. This part of the Lahaway Creek is designated FW2 (New Jersey Department of Environmental Protection, 2008). This basin is moderately undeveloped; mixed deciduous and coniferous forested and wetland areas comprise 80 percent of the basin. Cropland accounts for less than 5 percent of the basin, and most of this is in one localized field $0.3 \mathrm{mi}$ upstream from the monitoring site. Urban land uses constitute 13.6 percent of the basin and are mostly low density and suburban residential areas. The suburban areas are located in the lower part of the basin. Development has increased by more than 35 percent during

\footnotetext{
${ }^{1}$ Most waterbodies within New Jersey have been assigned a surface-waterquality classification (New Jersey Department of Environmental Protection, 1998). Freshwater bodies identified as FW1originate in and lie wholly within Federal or State parks, forests, fish and wildlife lands, and other special holdings and are to be maintained in their natural state of quality and not subjected to any manmade wastewater discharges. Freshwater bodies designated FW2 are water used for maintenance, migration and propagation of the natural and established biota, primary and secondary contact recreation (swimming, boating, and fishing), industrial and agricultural water supply, and public water supply after conventional filtration treatment. Regulations for SE1 waters, which are saline waters of estuaries, are similar to FW2 water regulations and also permit shellfish harvesting. $\mathrm{C} 1$ is a specific designation for the protection from measurable changes in the water-quality characteristics clarity, color, scenic setting, and other characteristics of aesthetic value, and exceptional ecological significance, exceptional recreational significance, exceptional water-supply significance, or exceptional fisheries resource(s).
}

1986-97 and consists mostly of rural and low-density residential areas with some suburban development.

The monitoring site on the Gravelly Run (UND2), near Laurel Lake in Cumberland County, New Jersey, receives water from an area of $3.3 \mathrm{mi}^{2}$ and is located entirely within boundaries of the Edward G. Bevan Wildlife Management Area $^{2}$ (fig. 6). Scheduled measurements of various waterquality constituents (including all constituents investigated in this study) have been made at this site by the USGS since 1983. Gravelly Run is classified as an FW2 (C1) stream. This basin is almost entirely undeveloped, with the exception of several paved and unpaved access roads. Most of the area (more than 99 percent) consists of forests - upland deciduous and coniferous forests - and wetlands. Several open areas are maintained to preserve wildlife habitat. There is no agricultural activity in this basin. Wildlife Management Areas are protected by the New Jersey Department of Environmental Protection, so this basin will most likely remain undeveloped in the future.

The monitoring site on Cooper River (URB1; fig. 7), located in Haddonfield in Camden County, New Jersey, receives water from an area of $17.8 \mathrm{mi}^{2}$, and the entire stream is classified FW2 ${ }^{1}$ (New Jersey Department of Environmental Protection, 2004a). This basin is moderately urbanized (about 69.2 percent) and includes mostly scattered medium-density residential areas (suburban in nature) and commercial and business districts. Urban areas are mostly concentrated near the lower part of the basin; agricultural, forested, wetland, and other land uses are mostly located at the basin headwaters. Within the study basin, two small tributaries to the upper Cooper River-Nicholson Branch and Woodcrest Creekdrain areas used for extractive mining, which may increase erosion during stormflow and cause increased concentrations of suspended sediment and total phosphorus. Mining land use may cause increased acidity during stormflow (Matter and Ney, 1981). A $0.3 \mathrm{mi}^{2}$ golf course area drains into the Woodcrest Creek. Trends in development during 1986-97 indicate that conversion to urban land uses, mostly suburban residential development, has increased only slightly (5 percent), although during this period forested and wetland areas have decreased by 15 percent (U.S. Geological Survey, 1986; Lathrop, 2000).

The monitoring site on South Branch Big Timber Creek (URB2), located in Grenloch in Gloucester County, New Jersey, receives water that drains an area of $4.3 \mathrm{mi}^{2}$ (fig. 8). South Branch Big Timber Creek drains into the Big Timber Creek, which is classified FW2 for the entire length of the stream (New Jersey Department of Environmental Protection, 2008). This basin is moderately urban (about 73.7 percent), mostly suburban areas and commercial districts. Rural and low density residential areas occupy the eastern and western edges of the basin. A $0.2 \mathrm{mi}^{2}$ golf course is located near a

\footnotetext{
${ }^{2}$ The Edward G. Bevan Wildlife Management Area is administered by the New Jersey Division of Fish and Wildlife, Bureau of Land Management. New Jersey's Wildlife Management Area Systems are protected areas that provide public access to fishing, hunting, and various other outdoor recreational activities.
} 


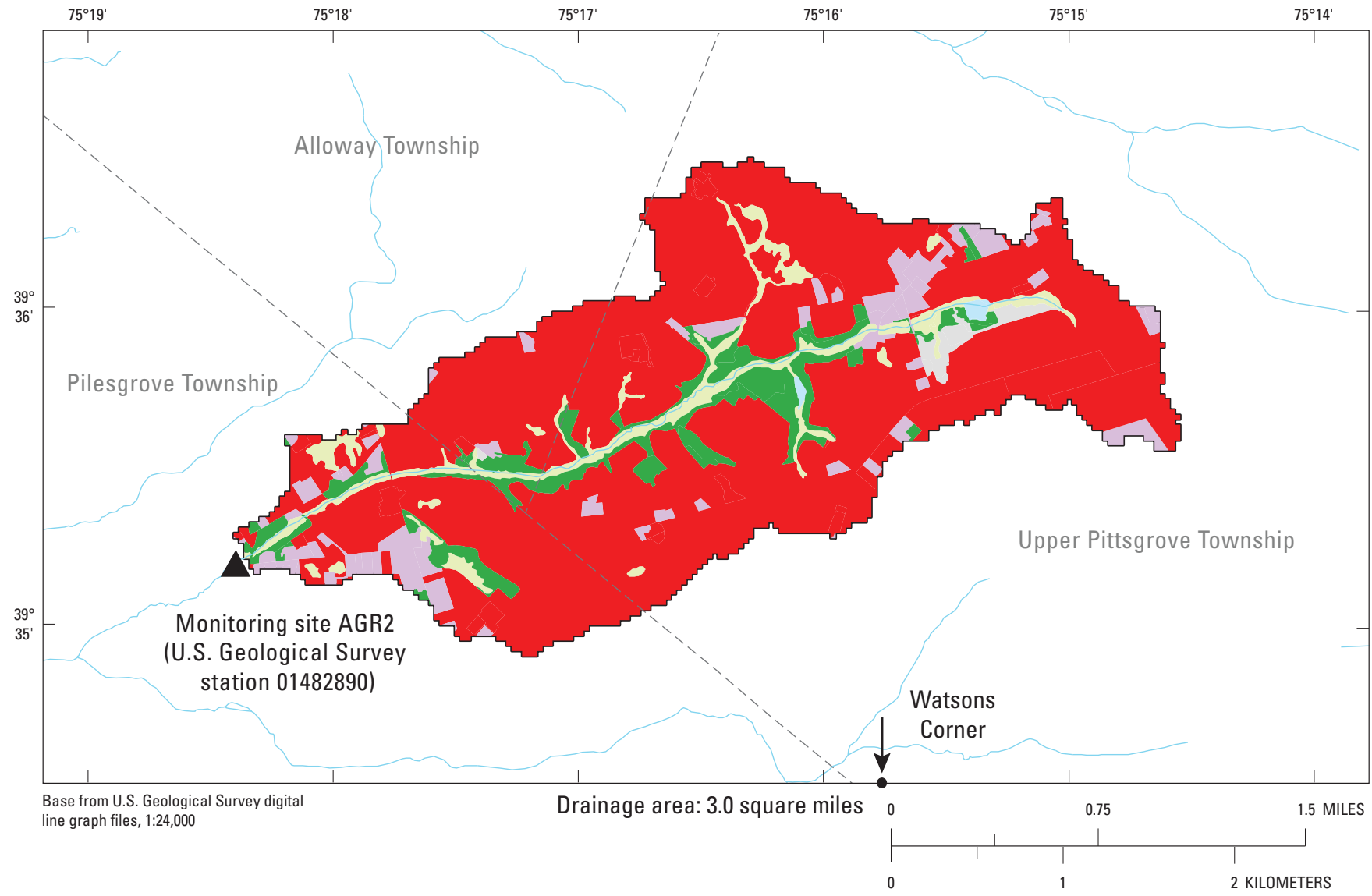

EXPLANATION
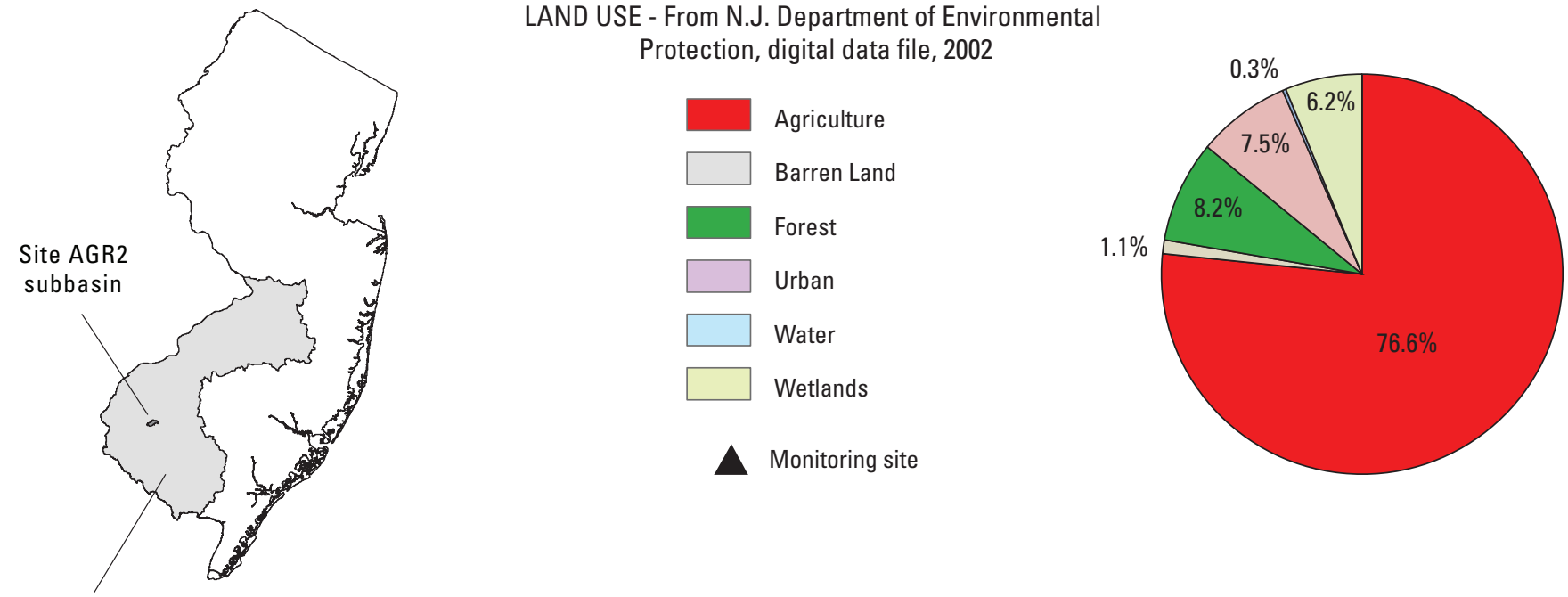

Lower Delaware

River Basin

Figure 4. Land use in site AGR2 drainage basin, lower Delaware River Basin in New Jersey. 


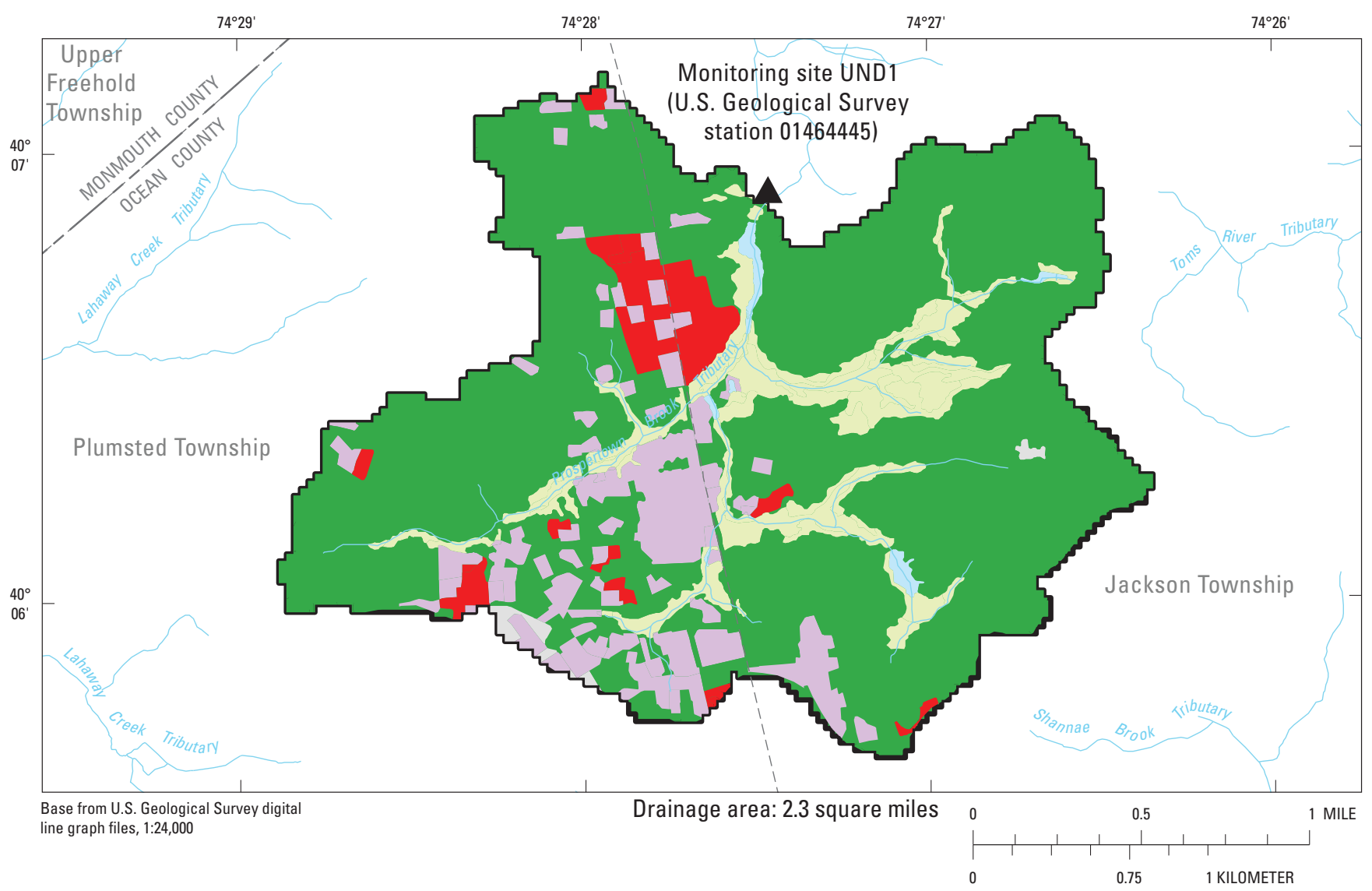

EXPLANATION

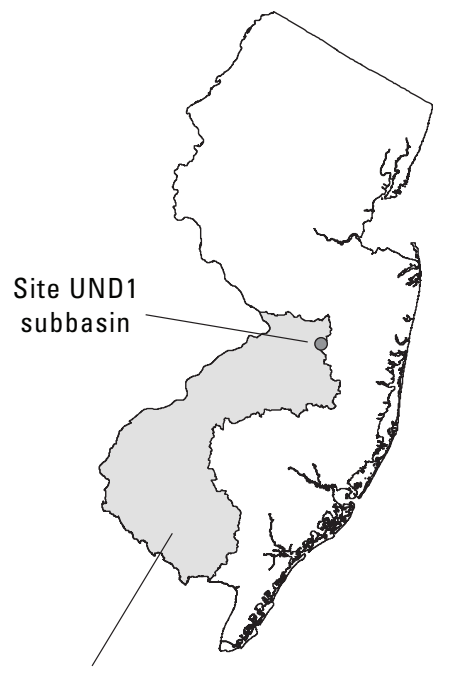

LAND USE - From N.J. Department of Environmental

Protection, digital data file, 2002

\begin{tabular}{|c|}
\hline Agriculture \\
\hline Barren Land \\
\hline Forest \\
\hline Urban \\
\hline Water \\
\hline Wetlands \\
\hline Monitoring site \\
\hline
\end{tabular}

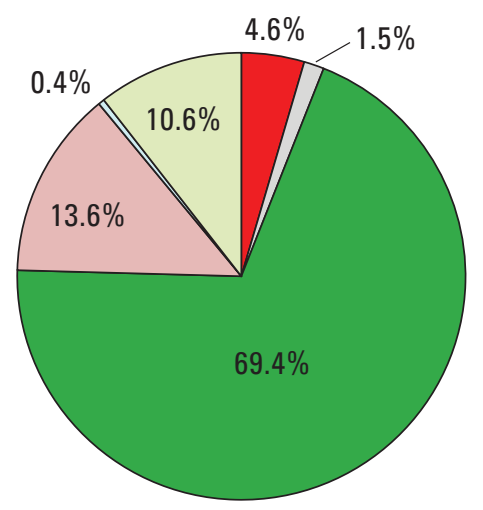

Lower Delaware

River Basin

Figure 5. Land use in site UND1 drainage basin, lower Delaware River Basin in New Jersey. 


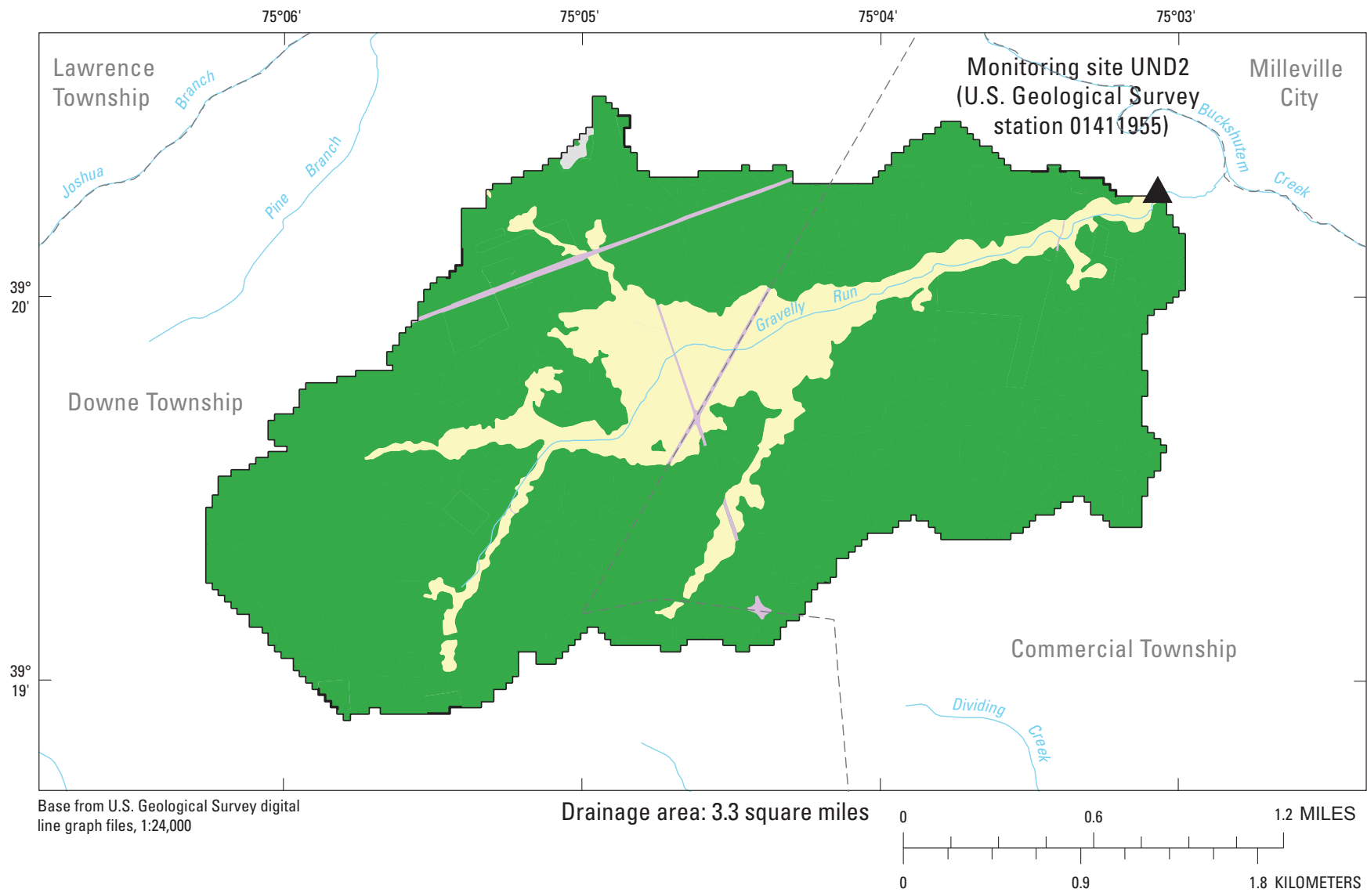

EXPLANATION

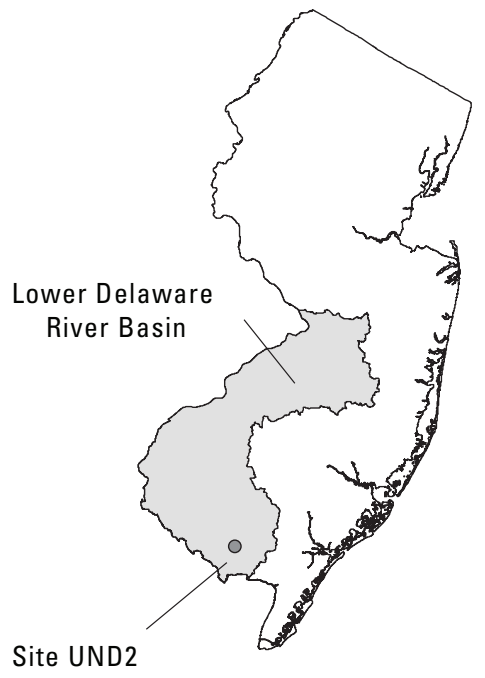

LAND USE - From N.J. Department of Environmental Protection, digital data file, 2002

\begin{tabular}{ll}
\hline & Agriculture \\
\hline & Barren Land \\
\hline & Forest \\
\hline & Urban \\
\hline & Water \\
\hline & Wetlands \\
\hline & Monitoring site
\end{tabular}

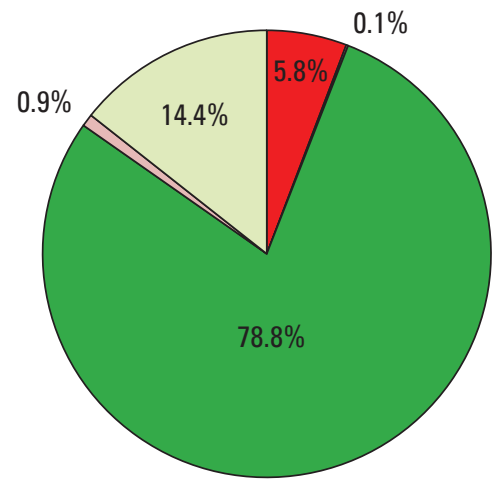

Figure 6. Land use in site UND2 drainage basin, lower Delaware River Basin in New Jersey. 


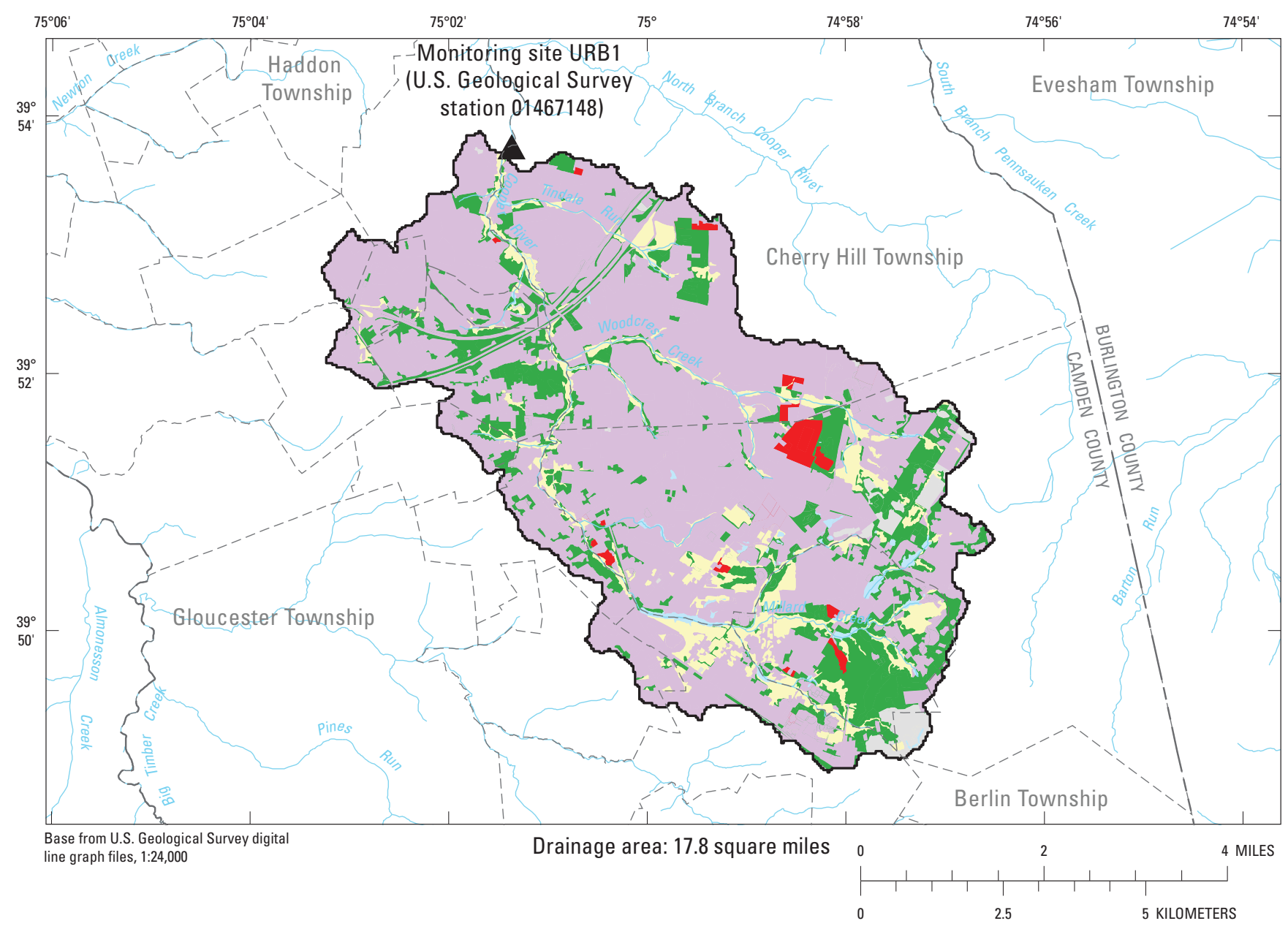

EXPLANATION

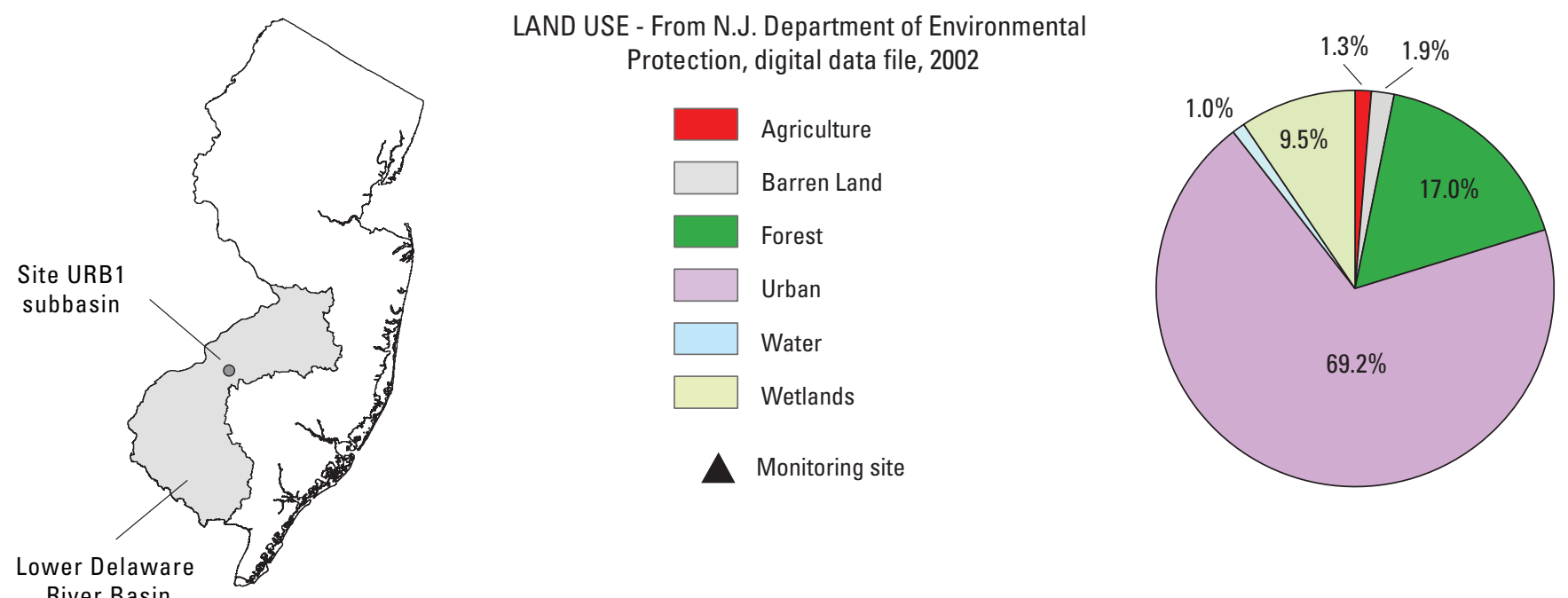

River Basin

Figure 7. Land use in site URB1 drainage basin, lower Delaware River Basin in New Jersey. 


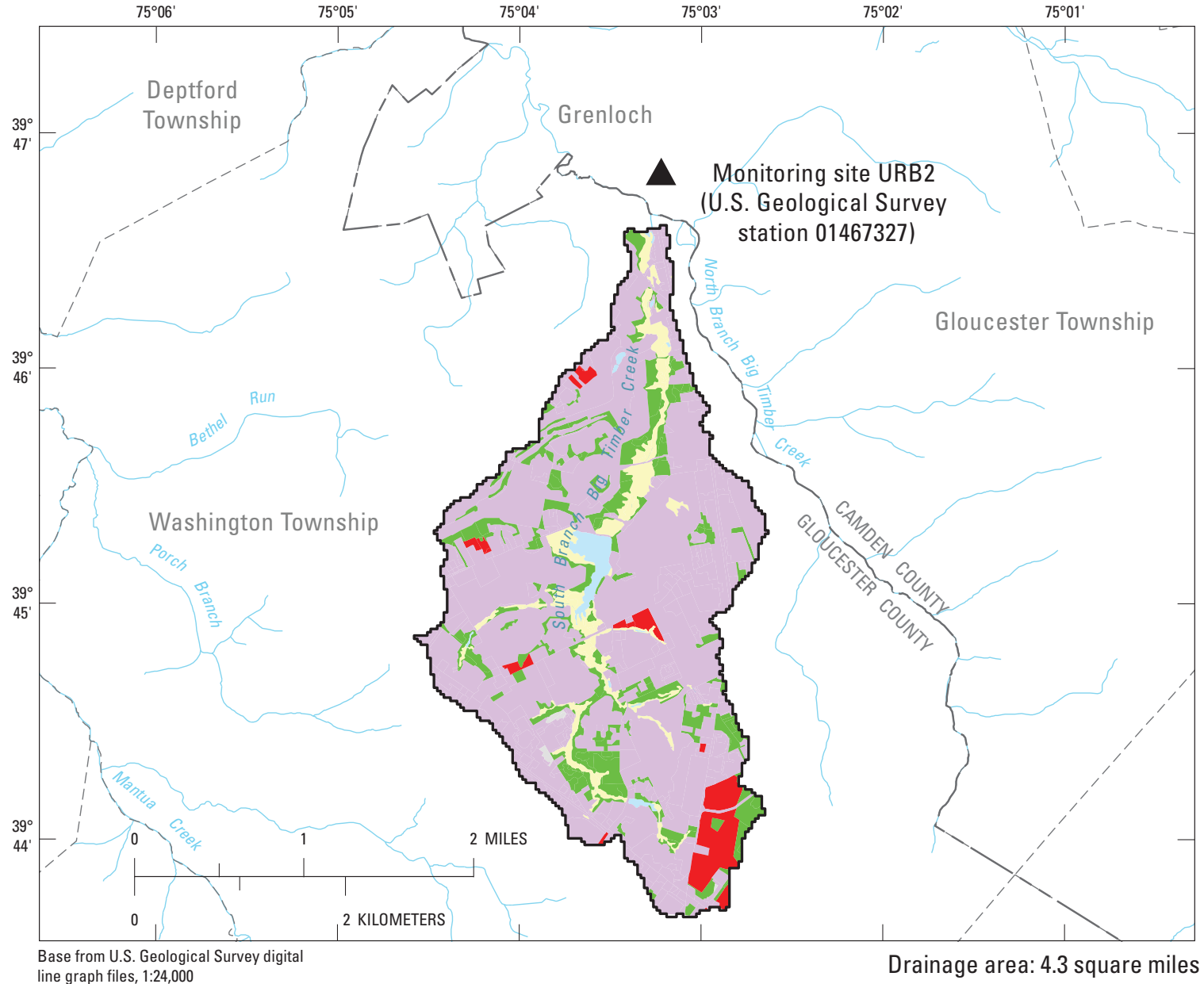

EXPLANATION
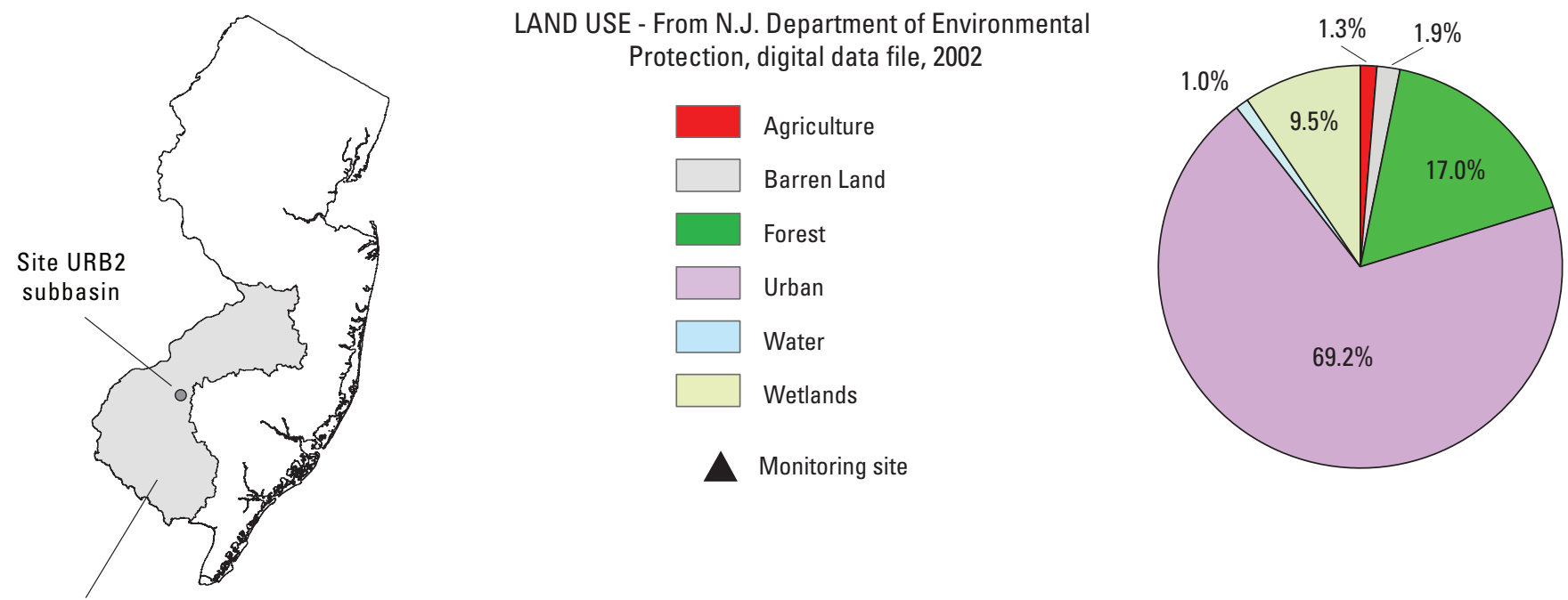

Lower Delaware

River Basin

Figure 8. Land use in site URB2 drainage basin, lower Delaware River Basin in New Jersey. 
tributary $0.6 \mathrm{mi}$ upstream from the monitoring site, which may contribute to elevated total nitrogen and phosphorus loads during stormflow and base flow from applications of fertilizers (Walker and Branham, 1992). About 3.9 percent of the basin is agricultural; one distinct cropland area is located near the basin headwaters. The remaining forested and wetland areas, which account for 20.7 percent, are highly fragmented throughout the basin, and most are located as buffers along the stream boundaries. A 1,500 $\mathrm{ft}^{2}$ impoundment surrounded by deciduous wooded wetland is located about $2 \mathrm{mi}$ upstream from the monitoring site. During 1986-97, forested and wetland areas in the basin decreased by about 15 percent, and agricultural areas decreased by more than 50 percent; suburban residential and commercial development increased proportionally (U.S. Geological Survey, 1986; Lathrop, 2000). These trends of urbanization may be continuing. The remaining undeveloped land in this basin is mostly fragmented, however, and may reduce the amount of total area available for development in the future.

\section{Data Collection}

\section{Water-Quality and Streamflow Data}

Water-quality samples were collected and stream stage was measured simultaneously eight times during base flow and eight times during stormflow at each site. In most cases, baseflow measurements were made within 1 day of each storm sample. Measurements were made during the growing season (April 1-October 31) and nongrowing season (November 1March 31). The dates for the growing and nongrowing seasons are based on the average times of the first and final frosts in New Jersey (Ruffner and Bair, 1977).

For sample collection during base flow, a maximumrainfall criterion of less than $0.1 \mathrm{in}$. during the 5 days prior to sampling was initially specified to ensure that the stream had returned to base flow after the previous stormflow event. The beginning of base flow is defined as the time after the cessation of precipitation when direct runoff into the stream has ended (Gray, 1970). At this time, the falling limb of the hydrograph typically assumes the appearance of exponential decline. USGS real-time streamgage stations located near each selected monitoring station were used as references. The six tributaries returned to base flow 1.5 to 3 days after the end of precipitation during three precipitation events (November 7 to December 8, 2004), which is consistent with the relation given by Linsley and others (1975):

$$
\mathrm{N}=\mathrm{A}^{0.2}
$$

where

$$
\begin{aligned}
\mathrm{N}= & \text { number of days between the storm peak } \\
& \text { and the end of runoff, and } \\
\mathrm{A}= & \text { drainage-basin area, in square miles. }
\end{aligned}
$$

In order to assess whether base-flow conditions have been reached, real-time stream-stage data at several USGS sites were viewed on the NWIS website. Each study site was assigned a reference site, located on a nearby stream of similar size. Table 5 lists the reference sites, which were accessed at http://waterdata.usgs.gov/nj/nwis/ current/?type $=$ flow\&group_key=basin_cd in order to assess whether base-flow conditions had been reached. A map showing the locations of the reference sites is shown at http://waterdata.usgs.gov/nj/nwis/rt.

A minimum-rainfall criterion for sample collection during stormflow in the growing and nongrowing season, 0.5 in., was based on precipitation data collected at Trenton, Wrightstown, Mount Holly, Caldwell, and Millville, New Jersey, weather stations operated by the National Oceanic and Atmospheric Administration.

Water-quality constituents that were analyzed are shown in table 6. All water-quality analyses were conducted by NJDEP personnel. Values of $\mathrm{pH}$, specific conductance, stream stage, and temperature were continuously monitored during each event using a YSI 6000-series water-quality monitoring system (sonde), which measured and recorded a value for each constituent every 5 to 15 minutes.

Stream stage and streamflow (discharge) were measured at five of the six sites over a range of flow conditions from base flow to stormflow. Discharge for the sixth site, URB1, was determined from data supplied by the USGS real-time streamgage station at Cooper River at Haddonfield (station located 01467150 , located $0.9 \mathrm{mi}$ downstream).

During base flow, stream stage was measured manually from staff plates and reference marks at the time the waterquality samples were collected. During most storms, stream stages were automatically recorded every 5 to 15 minutes by the sondes. Stream stage also was measured manually using staff plates at the beginning, middle, and end of most storms in order to confirm the sonde records.

Stream stages measured by the pressure transducer in the sondes (automated measurements) were verified by occasionally making manual stream-stage measurements. Stream-stage measurements obtained by directly reading the stage from a staff plate or reference mark (manual measurements, fig. 9) are considered more reliable than automated measurements.

During base flow, water samples were collected and discrete measurements of specific conductance, $\mathrm{pH}$, temperature, and dissolved measurements were made. Automated samplecollection equipment was used to collect water samples from each of the six study sites for analysis for chemical and biological constituents. Samples were not collected at regularly timed intervals but, rather, were timed so that collection occurred during each limb of the hydrograph. Due to logistical issues, unpredictability of storm duration, and personnel safety concerns, samples were not collected during the entire duration of the storm. 
Table 5. Reference sites used to determine the number of days between the end of a storm and the return to stream base flow for six streams in the lower Delaware River Basin, New Jersey.

[USGS, U.S. Geological Survey]

\begin{tabular}{|c|c|c|c|c|}
\hline $\begin{array}{l}\text { Project } \\
\text { site }\end{array}$ & $\begin{array}{l}\text { USGS } \\
\text { station } \\
\text { number }\end{array}$ & Reference site & $\begin{array}{l}\text { USGS } \\
\text { station } \\
\text { number }\end{array}$ & $\begin{array}{l}\text { Days from end } \\
\text { of storm to } \\
\text { base flow }\end{array}$ \\
\hline Alloway (AGR2) & 01482890 & Salem River at Woodstown & 01482500 & 2.0 \\
\hline Gravelly Run (UND2) & 01411955 & Cohansey River at Seeley, NJ & 01412800 & 2.5 \\
\hline Blacks Creek (AGR1) & 0146452750 & Crosswicks Creek at Extonville & 01464500 & 3.0 \\
\hline Lahaway (UND1) & 01464445 & Crosswicks Creek at Extonville & 01464500 & 3.0 \\
\hline
\end{tabular}

\section{Determination of Yields}

Yields for total nitrogen, dissolved ammonia, dissolved nitrate, organic nitrogen, filtered orthophosphate, total suspended solids, and fecal coliform bacteria for all monitoring sites were computed by using the following equation:

$$
\mathrm{Y}=(\mathrm{C} \times \mathrm{Q} \times \mathrm{f}) / \mathrm{A},
$$

where

$$
\begin{aligned}
\mathrm{Y}= & \text { pounds per day per square mile or most } \\
& \text { probable number per day per square mile; } \\
\mathrm{C}= & \text { measured concentration, in micrograms } \\
& \text { per liter or most probable number per } 100 \\
& \text { microliters; } \\
\mathrm{Q}= & \text { instantaneous streamflow, in cubic feet per } \\
& \text { second; } \\
\mathrm{f}= & \text { conversion factor equal to } 0.0053936 \\
& \text { pound per microgram times seconds per } \\
& \text { day, times liters per cubic feet }((\mathrm{lb} / \mu \mathrm{g}) \\
& \left.(\mathrm{s} / \mathrm{d})\left(\mathrm{L} / \mathrm{ft}^{3}\right)\right) \text { if the concentration is in } \\
& \text { micrograms per liter or } 2.45 \mathrm{x} 107 \mathrm{~seconds} \\
& \text { per day times milliliters per cubic feet } \\
& \left((\mathrm{s} / \mathrm{d})\left(\mathrm{mL} / \mathrm{ft}^{3}\right)\right) \text { if the concentration is in } \\
& \text { most probable number per } 100 \text { milliliters, } \\
\text { and } & \text { drainage area, in square miles. }
\end{aligned}
$$

\section{Data Evaluation}

Hydrologic data consist of stream stage and streamflow measurements. Stream stage-to-streamflow relations (rating curves), prepared from simultaneous discharge and streamstage measurements, were used to convert stream-stage values to discharge values. Water-quality constituent concentrations and yields were then evaluated using nonparametric statistical methods to determine relations between water quality and streamflow, season, and percentage of development in the basins.
Annual loads of each constituent were determined in the following manner. The event-mean concentration of each constituent was determined, and then multiplied by the total streamflow for the monitoring period to calculate the total mass of the constituent for the monitoring event. The annual load is obtained by multiplying the total mass by the ratio of annual rainfall divided by the rainfall that produced the event.

\section{Hydrologic Data}

Stage-discharge relations, or rating curves, were developed from the simultaneous stream-stage and discharge measurements and were used to convert stream-stage values at the time of sampling to discharge values. Rating curves were developed by using standard USGS streamgaging procedures as described by Rantz and others (1982). An example of a rating curve is shown in figure 10 .

Rating curves developed for all sites showed reliable correlations between stream stage and discharge. Discharge values for sites AGR1, UND1, and URB2 could be determined from a single rating curve each. Determining discharge for site UND2 required two rating curves, one before and one after July 2004. The stage-to-streamflow relation for site AGR2 was inconsistent and was found to be properly represented by two different rating curves. The rating curve calculated using discharge measurements made closest, by date, to each sampling event was selected.

Streamgaging was not conducted at monitoring site URB1. Discharge at this site was estimated using data from the USGS real-time streamgage station at Cooper River at Haddonfield (USGS station 01467150), located approximately $5,000 \mathrm{ft}$ downstream from the sampling site URB1. An equation was developed to estimate the instantaneous discharge at site URB1 by using (1) the area of the basin draining to site URB1 and station 01467150, (2) the discharge measured at station 01467150 at 15-minute intervals in real time, (3) the relation between discharge and stream velocity at station 01467150 (gathered from manual discharge-measurement data collected since 1963), and (4) the distance between the two sites. This mathematical procedure requires three steps: (1) 


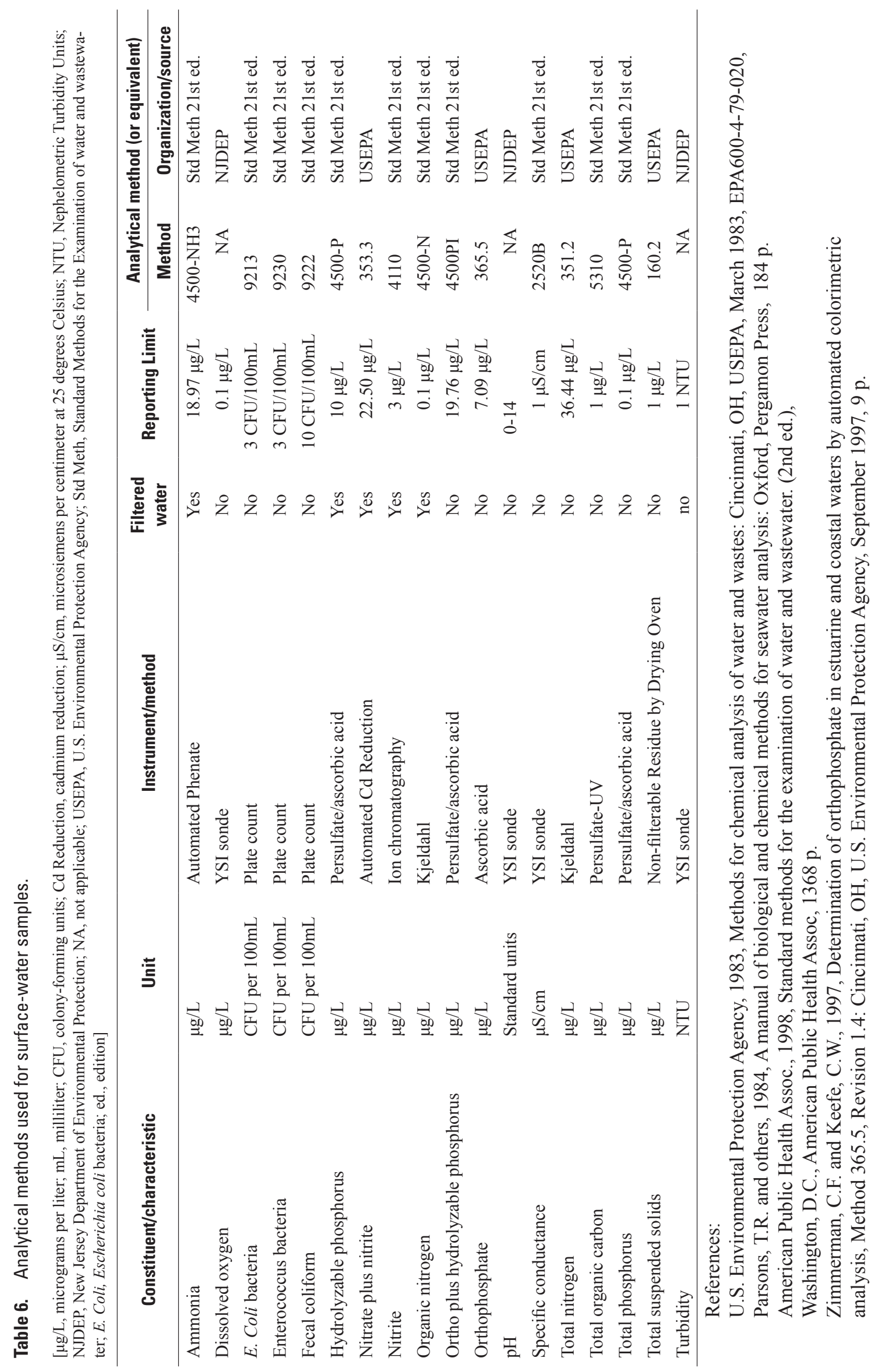




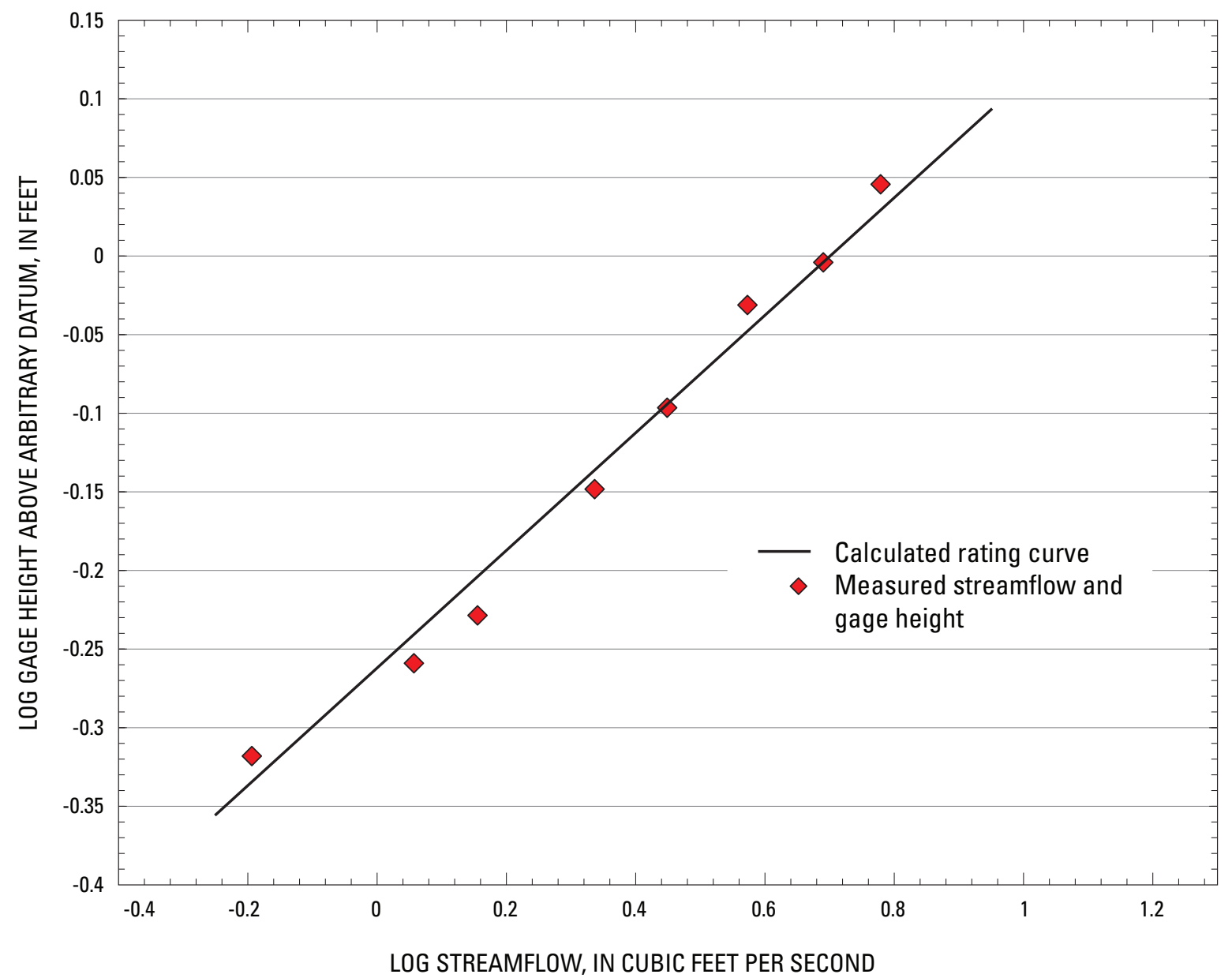

Figure 9. Example of a rating curve used for determining streamflow from measured stream stage for site UND2, Gravelly Run at Laurel Lake, New Jersey.

estimation of the discharge at site URB1 based on discharges observed at station 01467150 by proportionally correcting for drainage areas, (2) calculation of the time of travel for differences in discharge between the URB1 and station 01467150 based on velocities observed at varying streamgage heights at station 01467150, and (3) application of the time correction to site URB1 in order to assign the correct time to each calculated discharge value at URB1. The discharge received by site URB1 was calculated using the following formula based on measured discharge at station 01467150 and the difference between drainage basin areas of the two sites:

$$
\mathrm{Q}_{\mathrm{uss}}=\mathrm{Q}_{\mathrm{dss}} *\left[\mathrm{~A}_{\mathrm{uss}} / \mathrm{A}_{\mathrm{dss}}\right]^{\mathrm{n}},
$$

where

$$
\begin{aligned}
\mathrm{Q}_{\text {uss }}= & \text { discharge estimated at site UR1(upstream), } \\
\mathrm{Q}_{\text {dss }}= & \text { discharge estimated at station 01467150 } \\
& \text { (downstream), } \\
\mathrm{A}_{\text {uss }}= & \text { drainage area at site UR1 }\left(17.8 \mathrm{mi}^{2}\right), \\
\mathrm{A}_{\text {dss }}= & \text { drainage area at station } 01467150 \\
& \left(17.0 \mathrm{mi}^{2}\right), \text { and }
\end{aligned}
$$

$$
\begin{aligned}
\mathrm{n}= & \text { constant for drainage (Coastal Plain } \\
& \text { drainage, } \mathrm{n}=0.93)
\end{aligned}
$$

A correction was needed to account for a time lag between estimated velocities at the upstream site and downstream station. The method of Seddon (1900) as modified by Rantz and others (1982) was used.

\section{Discharge Hydrograph Extension and Base-Flow Separation}

Stage measurements were made manually at the beginning of each storm and during the rising limb of the hydrograph, but for most storms, only a few measurements were made during the falling limb of the hydrograph. In order to quantify the total discharge from each storm at each monitoring site, it was necessary to extend the storm-stage hydrographs in time and calculate discharge volumes for the falling limbs. This was accomplished by estimating the time at which runoff ended and the discharge value at that time, then applying an exponential function, which describes discharge as a 


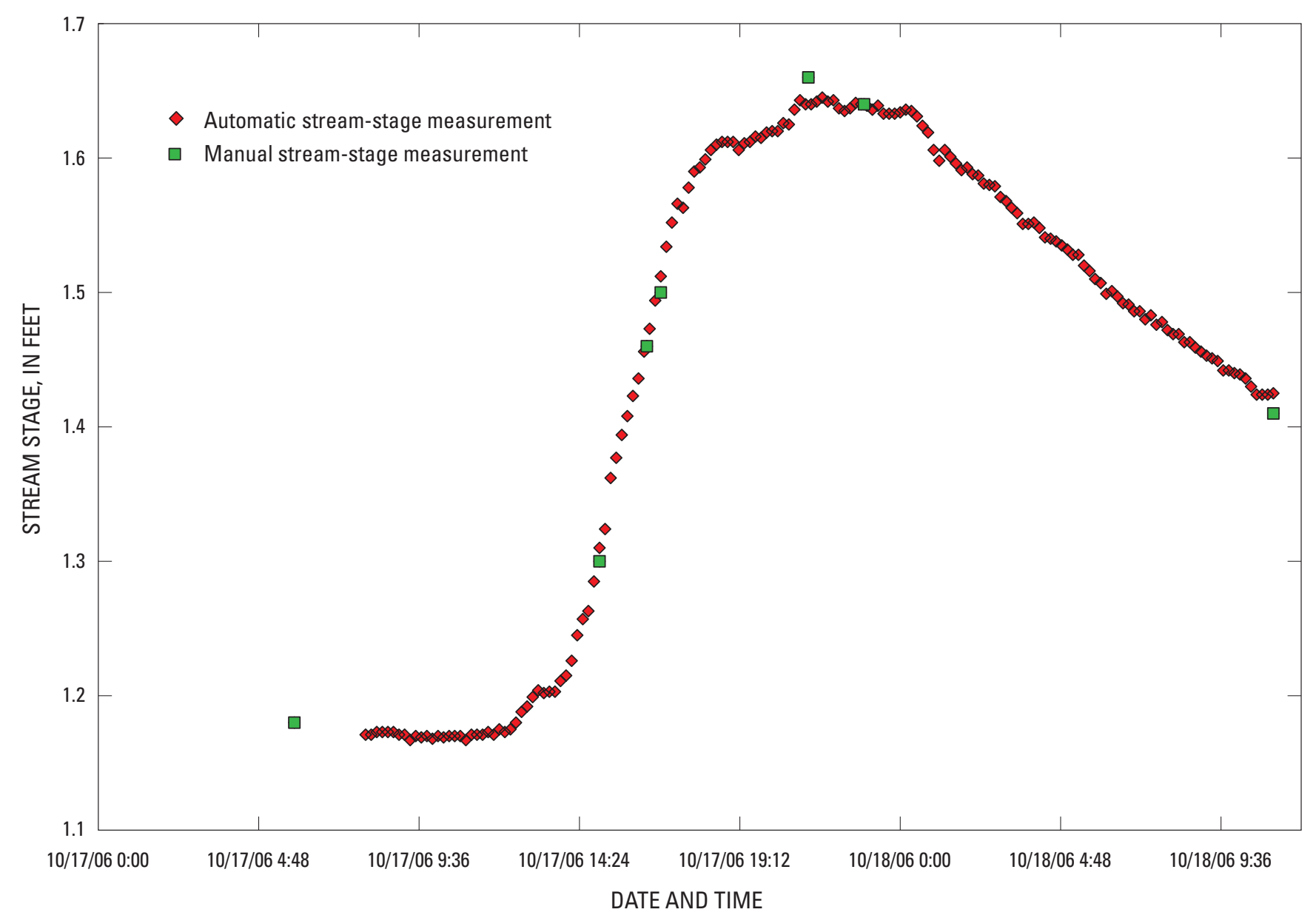

Figure 10. Example of a stream-stage hydrograph which includes automatic and manual stream-stage measuements for URB2, South Branch Big Timber Creek Tributary at Grenloch, New Jersey, October 17-18, 2006.

function of time, to the flow during the falling limb of the hydrograph. For the hydrograph extensions presented here it was assumed that precipitation ended at the time of the last measurement of streamflow. Additional precipitation, runoff, and stormflow were not considered in subsequent load calculations. Therefore, load calculations were made only from water-quality and measured streamflow data, and projected attenuation of loads from measured values; no assumptions were made about streamflow or water quality from unmonitored portions of storms.

The number of days between the storm peak and the end of runoff was estimated using equation (1). The base flow measured before precipitation began was used as the final base-flow value for the end of the event.

Discharge during the falling limb of a hydrograph decreases exponentially over time (Gray, 1970) and can be expressed as

$$
\mathrm{Q}_{2}=\mathrm{Q}_{1} \mathrm{~K}^{-\Delta t}
$$

where

$$
\begin{aligned}
\mathrm{Q}_{1} \text { and } \mathrm{Q}_{2} & =\text { discharge rates at two times during the } \\
& \text { falling limb; } \\
\mathrm{K} & =\text { constant, and } \\
\mathrm{t} & =\text { time elapsed between measurements. }
\end{aligned}
$$

The equation can be modified slightly to describe exponential decline in discharge from the last stage measurement $\left(Q_{1}\right)$ to the end of runoff $\left(Q_{2}\right)$.

$$
\mathrm{Q}_{2}=\mathrm{Q}_{1} \mathrm{e}^{\mathrm{e} \Delta \Delta \mathrm{t}},
$$

where

$$
\text { e } \quad=\text { base of the natural logarithm. }
$$

The constant $b$ is determined by setting $\mathrm{Q}_{2}$ to the baseflow discharge value, defining $\Delta t$ as the elapsed time between the last stage measurement and the end of runoff, and solving for $b$.

Base-flow separation was approximated by drawing a line from the base-flow discharge value immediately before the storm to the discharge value at the end of the storm, which 
corresponds to the end of runoff. Therefore, the base-flow discharge volume during a storm is the represented by the area of the quadrilateral on the hydrograph defined by the beginning and ending times of the storm and the associated streamflow values.

\section{Water-Quality Data}

All analyses were conducted by the NJDEP Bureau of Marine Water Monitoring Leeds Point Laboratory. Water samples were analyzed for total nitrogen, ammonia, nitrate plus nitrite, total phosphorus, orthophosphorus, total suspended solids, and bacteria (Escherichia coliform (E. coli) and fecal coliform). Nitrate was calculated as the difference between nitrate plus nitrite and nitrite. Organic nitrogen was calculated as the difference between total nitrogen and the sum of ammonia and nitrate plus nitrite.

In this report, concentrations of all nitrogen species are presented in micrograms per liter of nitrogen $(\mathrm{N})$. Concentrations of total phosphorus and orthophosphate are presented in micrograms per liter of phosphorus (P). Concentrations of total suspended solids are expressed as milligrams per liter, and concentrations of bacteria are presented in the most probable number of bacteria per 100 milliliters of sample. The term "total concentration" refers to concentrations of analytes determined from unfiltered water samples.

\section{Statistical Methods}

A statistical package (Spotfire S-Plus 8.1, Tibco Software, Inc., Palo Alto, CA) was used for all statistical calculations and related graphics. Base-flow and stormflow data were evaluated separately. Null hypotheses were developed to test for differences among concentrations and yields of each constituent in water samples from the six sites and differences in water quality between growing and nongrowing seasons.

Because water-quality data tend to be non-normally distributed, tend to be censored by detection limits, and often have substantial numbers of outliers, hypothesis testing of data with these characteristics without appropriate transformations is inadvisable (Helsel and Hirsch, 2002). Therefore, nonparametric statistical tests were used in this investigation. There is slightly decreased power for the statistical tests for normally distributed data (Helsel and Hirsch, 2002). The loss of power, however, can be far greater when false assumptions of normality are made and parametric methods are erroneously employed (Zar, 1974). Two-way analysis of variance (ANOVA) of ranked data was used to simultaneously test for differences among concentrations and yields of constituents at different sites, and for differences between growing and nongrowing seasons. All statistical tests were used to compare mean ranks and median ranks. The null hypotheses $\left(\mathrm{H}_{\mathrm{o}}\right)$ and alternate hypotheses $\left(\mathrm{H}_{\mathrm{A}}\right)$ can be stated in the form shown below, using nitrogen concentration as an example.
$\mathrm{H}_{\mathrm{ol}}$ There is no difference between growing and nongrowing seasons regarding the effects on the concentration of nitrate as nitrogen $\left(\mathrm{NO}_{3}-\mathrm{N}\right)$ (significance level=0.05).

$\mathrm{H}_{\mathrm{a} 1}$ There is a difference between growing and nongrowing seasons regarding the effects on the concentration of nitrate as nitrogen $\left(\mathrm{NO}_{3}-\mathrm{N}\right)$ (significance level $=0.05$ ).

$\mathrm{H}_{\mathrm{o} 2}$ There is no difference among the six streams in concentration of nitrate as nitrogen $\left(\mathrm{NO}_{3}-\mathrm{N}\right)$ ( significance level $=0.05$ ).

$\mathrm{H}_{\mathrm{a} 2}$ There are differences among the six streams in concentration of nitrate as nitrogen $\left(\mathrm{NO}_{3}-\mathrm{N}\right)$ ( significance level=0.05).

The same set of null and alternate hypotheses were applied to concentrations and yields of all phosphorus and nitrogen species measurements, as well as to total suspended solids measurements and to bacterial-density measurements. The Tukey multiple comparison test of ranked data was used to conduct pair-wise comparisons of concentrations and yields of constituents at different sites. Here, each null hypothesis states that there is no difference between a given pair of streams in concentration of a water-quality characteristic (for example, $\mathrm{NO}_{3}-\mathrm{N}$ ). Precipitation, water-quality data, and streamflow data were used to calculate loads of total nitrogen and phosphorus for the storms monitored for the entire period of record and for an annual-average basis. In this method, measured concentrations of constituents and measurements of streamflow during base flow and stormflow were used to directly calculate the mass loads of nitrogen and phosphorus species during sampling events. These load values were then extrapolated over the entire period of record by relating runoff to precipitation and calculating the amount of runoff during the period of record. Event-mean concentrations of chemical species were then used with the calculated runoff totals to determine total and average annual loads for each chemical constituent. The load during base flow was then separated from total load, and the difference between those was calculated as runoff load. The method also was applied separately to events monitored during growing and nongrowing seasons.

The first step was to determine the event mean concentrations of total nitrogen and total phosphorus for each storm sampling event using

$$
\mathrm{EMC}=\sum_{\mathrm{i}=1}^{\mathrm{n}} \mathrm{C}_{\mathrm{i}} \mathrm{D}_{\mathrm{i}} / \sum_{\mathrm{i}=1}^{\mathrm{n}} \mathrm{D}_{\mathrm{i}}
$$

where

$$
\begin{aligned}
\text { EMC }= & \text { event mean concentration of the } \\
& \text { water-quality characteristic of interest } \\
& \text { (total nitrogen or total phosphorus), in } \\
& \text { milligrams per liter, for a storm sampling } \\
& \text { event; } \\
\mathrm{n} \quad & \text { number of water-quality measurements } \\
& \text { made during the event; }
\end{aligned}
$$




$$
\begin{aligned}
& \mathrm{C}_{\mathrm{i}}=\text { concentration of the water-quality } \\
& \text { characteristic of interest, in milligrams per } \\
& \text { liter, for measurement I, and } \\
& \mathrm{D}_{\mathrm{i}} \quad=\text { streamflow value at the time of the water- } \\
& \text { quality measurement } i \text {. }
\end{aligned}
$$

The second step was to determine the event total flow during the storm. This calculation, which includes streamflow from the beginning of precipitation to the end of event monitoring, and the attenuating flow as the stream returned to base flow (assuming no further precipitation), was made using

$$
\mathrm{ETF}=\sum_{\mathrm{i}=1}^{\mathrm{v}}\left(\mathrm{D}_{\mathrm{i}}+\mathrm{D}_{\mathrm{i}+1}\right) / 2 *\left(\mathrm{t}_{\mathrm{i}+1}-\mathrm{t}_{\mathrm{i}}\right)
$$

where

$$
\begin{aligned}
\mathrm{ETF}= & \text { event total flow, in cubic feet; } \\
\mathrm{v}= & \text { number of stream discharge measurements; } \\
& \text { and } \\
\mathrm{t}_{\mathrm{i}+1}-\mathrm{t}_{\mathrm{i}}= & \text { time elapsed between two discharge } \\
& \text { measurements, in seconds. }
\end{aligned}
$$

The total mass of the water-quality characteristic was then calculated for each storm event:

$$
\mathrm{TM}_{\mathrm{e}}=\mathrm{EMC}^{*} \mathrm{ETF}^{* \mathrm{f}}
$$

where

$$
\begin{aligned}
\mathrm{TM}_{\mathrm{e}}= & \text { total mass of the water-quality } \\
& \text { characteristic for storm event } \mathrm{e}, \text { in } \\
& \text { pounds and } \\
\mathrm{f} \quad= & \text { conversion factor to convert mass from } \\
& \text { milligrams to pounds. }
\end{aligned}
$$

Base-flow mass was then calculated and subtracted from the total mass of each water-quality characteristic for each event to determine runoff mass values:

$$
\begin{aligned}
& \mathrm{BFM}_{\mathrm{e}}=\mathrm{C}_{\mathrm{bf}} * \mathrm{D}_{\mathrm{bf}} * \mathrm{~g}, \\
& \mathrm{SFM}_{\mathrm{e}}=\mathrm{TMe}-\mathrm{BFMe},
\end{aligned}
$$

where

$$
\begin{aligned}
& \mathrm{BFM}_{\mathrm{e}}=\text { base-flow mass of the water-quality } \\
& \text { characteristic of interest for storm event e; } \\
& \mathrm{C}_{\mathrm{bf}}=\text { concentration of the water-quality } \\
& \text { characteristic of interest, in milligrams per } \\
& \text { liter; } \\
& \mathrm{D}_{\mathrm{bf}} \quad=\text { base-flow discharge value, in cubic feet per } \\
& \text { second; } \\
& \mathrm{g} \quad=\text { conversion factor to convert mass from } \\
& \text { milligrams to pounds and liters to cubic } \\
& \text { feet; and }
\end{aligned}
$$

$$
\mathrm{SFM}_{\mathrm{e}}=\begin{aligned}
& \text { mass of the water-quality characteristic of } \\
& \text { interest attributed to runoff for event } \mathrm{e} .
\end{aligned}
$$

Mass of the water-quality characteristic for the entire period of record was then calculated by dividing the event mass by the fraction of precipitation in the period of record represented by the storm events. This was done for total mass, runoff mass, and base-flow mass using

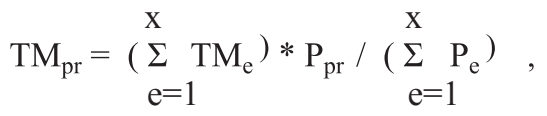

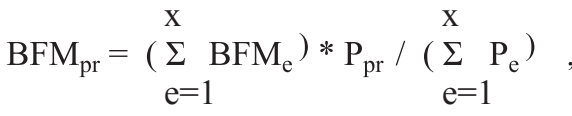

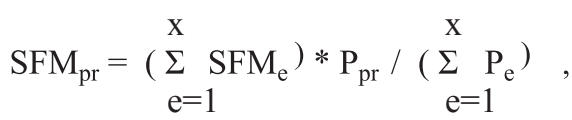

where

$$
\begin{aligned}
\mathrm{TM}_{\mathrm{pr}}= & \text { total mass of the water-quality } \\
& \text { characteristic for the entire period of } \\
& \text { record during which water-quality and } \\
& \text { streamflow were monitored; } \\
\mathrm{x} \quad= & \text { number of storms monitored; } \\
\mathrm{P}_{\mathrm{pr}}= & \text { total precipitation recorded during } \\
& \text { the period of record, in inches, at the } \\
& \text { meteorologic station closest to the } \\
& \text { monitoring site; and } \\
\mathrm{P}_{\mathrm{e}} \quad & \text { total precipitation during each storm, } \\
& \text { in inches, recorded at the meteorologic } \\
& \text { station closest to the monitoring site. }
\end{aligned}
$$

Annual load rates were then calculated by expressing the total mass on an annual basis:

$$
\begin{aligned}
\mathrm{TM}_{\mathrm{yr}} & =\mathrm{TM}_{\mathrm{pr}} *(365 / \mathrm{PR}), \\
\mathrm{BFMyr} & =\mathrm{BFMpr} *(365 / \mathrm{PR}), \\
\mathrm{SFMyr} & =\operatorname{SFMpr} *(365 / \mathrm{PR}),
\end{aligned}
$$

where

$$
\begin{aligned}
\mathrm{TM}_{\mathrm{yr}}= & \begin{array}{l}
\text { total mass of the water-quality } \\
\text { characteristic per year; }
\end{array} \\
\mathrm{BFM}_{\mathrm{yr}}= & \begin{array}{l}
\text { base-flow mass of the water-quality } \\
\text { characteristic per year; }
\end{array} \\
\mathrm{SFM}_{\mathrm{yr}}= & \begin{array}{l}
\text { runoff mass of the water-quality } \\
\text { characteristic per year; and }
\end{array} \\
\mathrm{PR} \quad= & \text { the period of record, in days. }
\end{aligned}
$$


Annual yields were then calculated by dividing total mass load values by the area of the subbasins.

\section{Relations of Water Quality to Streamflow, Season, and Land Development}

Variability of concentrations and yields of nutrient species as a result of land-use patterns was observed by using boxplots and nonparametric statistical methods. Hydrologic conditions and season (growing and nongrowing) were also explored as explanatory variables.

\section{Water-Quality Data}

Concentrations and yields of water-quality constituents differed among the six sites during base-flow and stormflow conditions. Concentrations and yields also differed between the growing and nongrowing seasons. Summary statistics for all water-quality data collected are shown in appendix 1. (A complete listing of water-quality data is available upon request from the U.S. Geological Survey, New Jersey Water Science Center. Inclusion of the complete data set was not feasible due to its large volume.) All data were subjected to rank transformation because hydrologic data are non-normally distributed.

Results of all ANOVA and Tukey statistical testing are reported in one table (table 7), which contains the results of all hypotheses testing to determine whether concentrations or yields of specific water-quality characteristics vary in conjunction with land-use patterns and season, during storms and during base flow. The first two columns of the table identify the water-quality constituent and hydrologic conditions (stormflow or base flow). The next three columns show whether the null hypotheses were accepted or rejected. The null hypotheses are (1) differences in the value of the water-quality characteristic during the growing and the non-growing seasons are not significant, (2) differences in the value of the water-quality characteristic among the six sites are not significant, and (3) the amount of interaction between the categories (season and site) is not significant. The significance level for all analyses was set at $\alpha=0.05$. The remainder of the table shows the results of the Tukey test, which is a multiple comparison technique used to test for significant differences between each possible pair of subgroups after an ANOVA null hypothesis has been rejected. The result of Tukey analysis is to rank (lowest to highest) the six sites in terms of the mean value of the constituent being evaluated. In table 7, the letters A through F are used to designate this ranking. In many cases, one or more pairs of sites do not demonstrate significant differences in the value of the constituent (for example, concentration of total nitrogen), and those sites receive the same letter. This same ranking and lettering designation is used in the box plot figures that follow in this section.

\section{Nitrogen}

Elevated concentrations of nitrogen species can degrade the quality of surface water as a resource (for drinking water and recreation) and as a habitat. Excess nitrogen can cause eutrophic conditions to occur in lakes and rivers, including excessive algal growth, reduced light below the water surface, depleted dissolved oxygen, and subsequent death of aquatic plant life, benthic organisms, and vertebrates.

Sources of nitrogen include atmospheric deposition, fixation by leguminous plants, animal waste, discharge from industry and sewage-treatment plants, discharge from individual septic systems, and commercial fertilizers applied to farmland, residential properties, and commercial properties. The relative importance of nitrogen sources was evaluated by Vitousek and others (1997), who estimated that, on an annual basis, 90 to 140 teragrams $(\mathrm{tg})$ of nitrogen are fixed globally by natural processes (bacterial activity and lightening), $140 \mathrm{tg}$ are fixed by human activities, and 40 tg are mobilized by human activities. Vitousek and others (1997) projected a continuing increase in human-mediated contribution, especially in developing countries where amending soil with additional nitrogen is a rapid, inexpensive way to substantially increase crop yields. The long-term consequences of this constantly increasing load of fixed nitrogen to the nitrogen cycle are not known; however, the increase in eutrophication of streams, lakes and estuaries is a certainty.

Nitrogen species as percentages of total nitrogen in base flow and stormflow samples are summarized in table 8 . Generally, the organic fraction tended to account for a higher percentage of total nitrogen in stormflow than in base-flow samples. Nitrite represented a minor fraction of total nitrogen in most samples, regardless of the site sampled, season, or hydrologic conditions. Nitrate was the most abundant species in most samples, and ammonia generally represented about 3 to 6 percent of total nitrogen.

\section{Total Nitrogen}

The sum of organic and inorganic species of nitrogen is reported as total nitrogen in units of micrograms per liter as N. In this investigation both filtered and unfiltered samples were analyzed for total nitrogen. The total nitrogen concentration did not differ significantly between filtered and unfiltered samples and was represented by the following linear relation:

$$
(\text { total } \mathrm{N}, \text { filtered })=0.95(\text { total } \mathrm{N}, \text { unfiltered }), \mathrm{R}^{2}=0.99
$$

In cases where only results from filtered samples were obtained, the value for the unfiltered sample was estimated by using this relation. Therefore, all total nitrogen concentrations are reported as unfiltered values, after applying the appropriate correction (dividing by 0.95 ) to total nitrogen concentrations determined for filtered samples. 


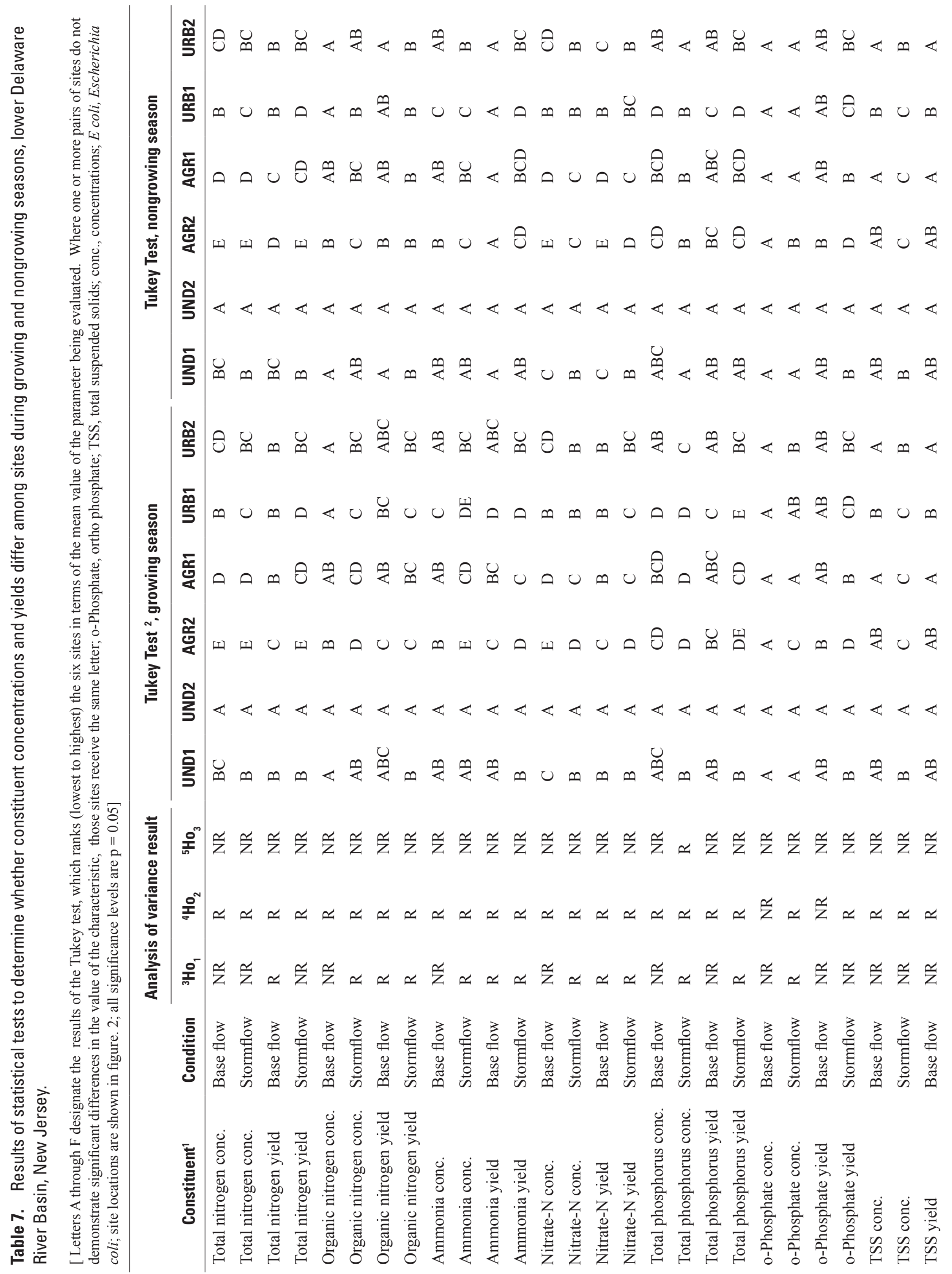




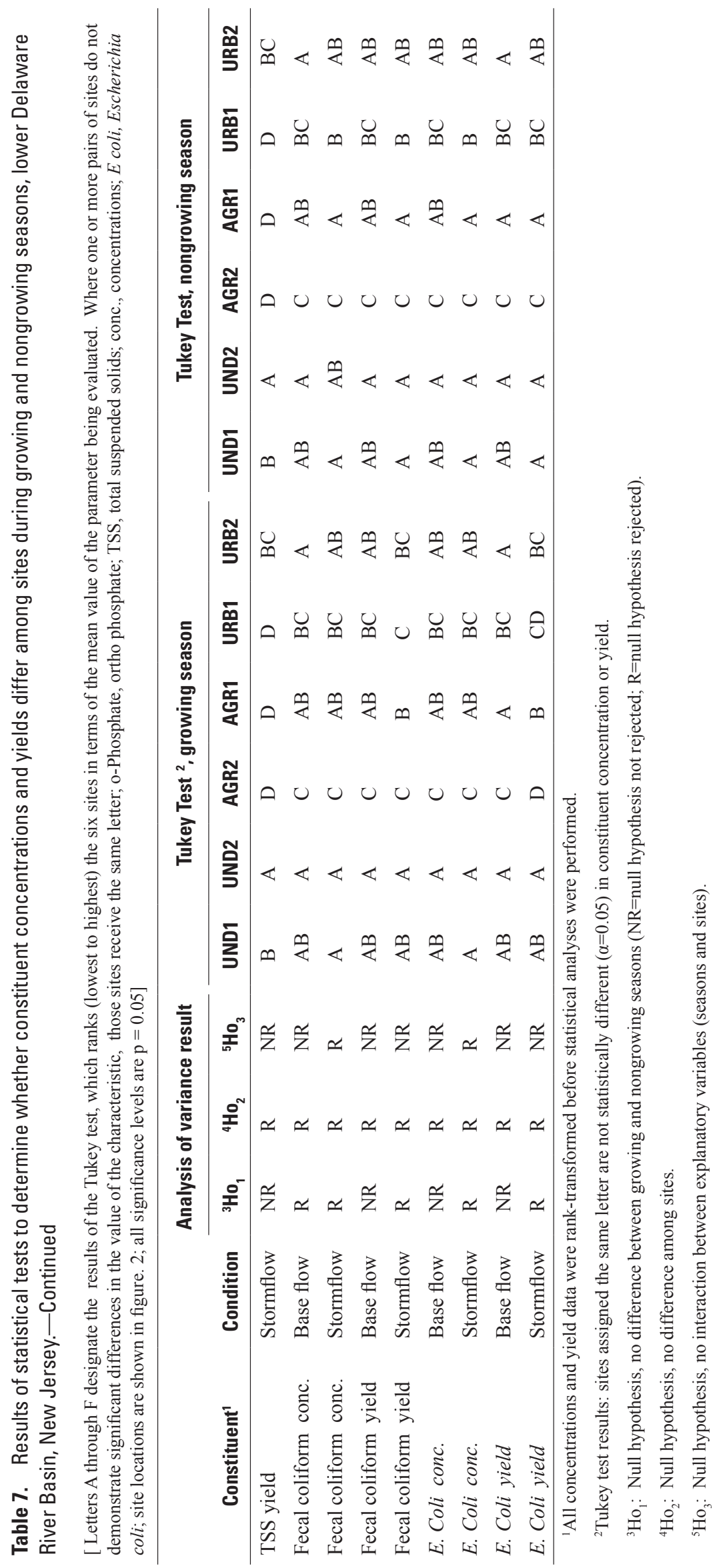


Table 8. Mean percentages of total nitrogen in unfiltered water samples represented by four nitrogen species for six streams in the lower Delaware River Basin, New Jersey.

[Values do not sum to 100 percent due to rounding]

\begin{tabular}{ccccc}
\hline \multirow{2}{*}{$\begin{array}{c}\text { Hydrologic } \\
\text { condition }\end{array}$} & \multicolumn{4}{c}{ Percent of total nitrogen concentration } \\
\cline { 2 - 5 } & Nitrite & Nitrate & Organic N & Ammonia \\
\hline Base flow & 0.8 & 85 & 11 & 3.5 \\
Stormflow & 1 & 61 & 32 & 5.6 \\
\hline
\end{tabular}

Box plots for total nitrogen concentrations during base flow and stormflow in growing and nongrowing seasons are shown in figure 11. ANOVA and Tukey test results also are shown in table 7. Median total nitrogen concentrations were significantly higher in water samples from agricultural sites than from all other sites. For base-flow samples, the median concentrations (Appendix 1) for sites AGR1 and ARG2 are 1,347 and $7,809 \mu \mathrm{g} / \mathrm{L}$ as $\mathrm{N}$, respectively, substantially greater than the highest median concentrations in samples from undeveloped sites (727 $\mu \mathrm{g} / \mathrm{L}$ as N, UND1) and urban sites ( $879 \mu \mathrm{g} / \mathrm{L}, \mathrm{URB} 2)$. Tukey test results show that total nitrogen concentrations are greater for AGR2 than for any other site under all flow and seasonal conditions. Concentrations of total nitrogen in samples from AGR1 were significantly higher than those at both undeveloped sites under all conditions. They also were higher than those at URB1 during stormflow, but not during baseflow, where Tukey analysis could not distinguish between total nitrogen concentrations in samples from sites

\section{AGR1 and URB2.}

There is a large difference in total nitrogen concentration between sites AGR1 and AGR2 (fig. 11). This may be partially explained by the greater percentage of farmland in the basin upstream from AGR2 (76.6 percent compared to 55.4 percent for AGR1). The larger percentage of wetlands in the AGR1 basin (18.6 percent compared to 6.2 percent for the AGR2 basin) may help to attenuate nitrogen before it reaches the stream. The third difference observed between these two sites is that cattle were seen near and in Alloway Creek (AGR2) but not Blacks Creek (AGR1) during sampling events. The larger basin area for AGR1 also may serve to distribute the loads over a longer period of time, resulting in a decrease in the maximum and mean concentrations.

Land-use percentages for the two urban sites were similar (69.2 and 73.7 percent urban land use for URB1 and URB2, respectively). Percentages of the other land-use categories for these two basins also were similar. Total nitrogen concentrations were not significantly different $(p=0.05)$ between these two sites during stormflow, but concentrations in samples from URB2 collected during base flow in the growing and nongrowing seasons were slightly greater than those from URB1.

The basin upstream from UND2 is almost entirely forest and wetlands and has total nitrogen concentrations significantly lower than any other site. UND1 has concentrations similar to those of the urban sites. This may be because UND1 has a substantial (13.6 percent) amount of urban development, as well as some agriculture adjacent to the creek.

Yields of total nitrogen for the six sites follow a similar pattern to that of concentrations (fig. 12). The total nitrogen yield for AGR2 was significantly greater than that for all other sites, and the yield for UND2 was lower than that for all other sites. Yields in base flow for the other four sites were not significantly different during the growing season but were greater for AGR1 than for the urban and undeveloped basins during the nongrowing season. Yields for AGR1 were greater than those of the undeveloped basins during growing and nongrowing seasons but were not distinguishable from those of the two urban basins.

\section{Nitrite Plus Nitrate}

Nitrite represents a minor percentage (about 1 percent in most cases) of total nitrogen concentrations in all water samples analyzed from all sites. Nitrite is an intermediate species in the biological nitrification part of the nitrogen cycle. Nitrosomonas are bacteria that oxidize ammonia to nitrite, and Nitrobacter are bacteria that further oxidize nitrite to nitrate. Therefore, nitrite is not considered a stable species under environmental conditions, and the low concentrations observed during this investigation are not surprising. Concentrations of nitrite were significantly higher in samples from site AGR2 than in samples from any other site, and samples from UND1 and UND2 tended to have lower concentrations than those from other sites. The same trend was observed for yields among the sites.

Nitrate accounts for most of the total nitrogen concentrations in most samples from all sites. Concentrations and yields of nitrate among the six sites are similar to those observed for total nitrogen (figs. 13 and 14). Concentrations in samples from site AGR2 were significantly higher than those for all other sites under base-flow and stormflow conditions in the growing and nongrowing seasons. The only exception is that the concentration for AGR2 cannot be distinguished from that for AGR1 during stormflow in the nongrowing season using the Tukey test, though it is evident from figure 13 that all values for AGR2 are greater than all values for AGR1. Nitrate concentrations in samples from site UND2, with a 99-percent undeveloped basin, are significantly lower than concentrations in samples from all other sites. Concentrations for site UND1 are more similar to those for the urban sites than those for site UND2. This is probably because much of the urban and agricultural land in the basin upstream from UND1 is clustered near the stream; thus, much of the runoff and base flow reaching UND1 has passed through land uses that contribute nitrate to surface water.

Nitrate yields were significantly higher in samples from AGR2 than from any other site under all conditions. During base flow in the nongrowing season, yields at AGR1 were significantly higher than for both undeveloped and both urban samples. 

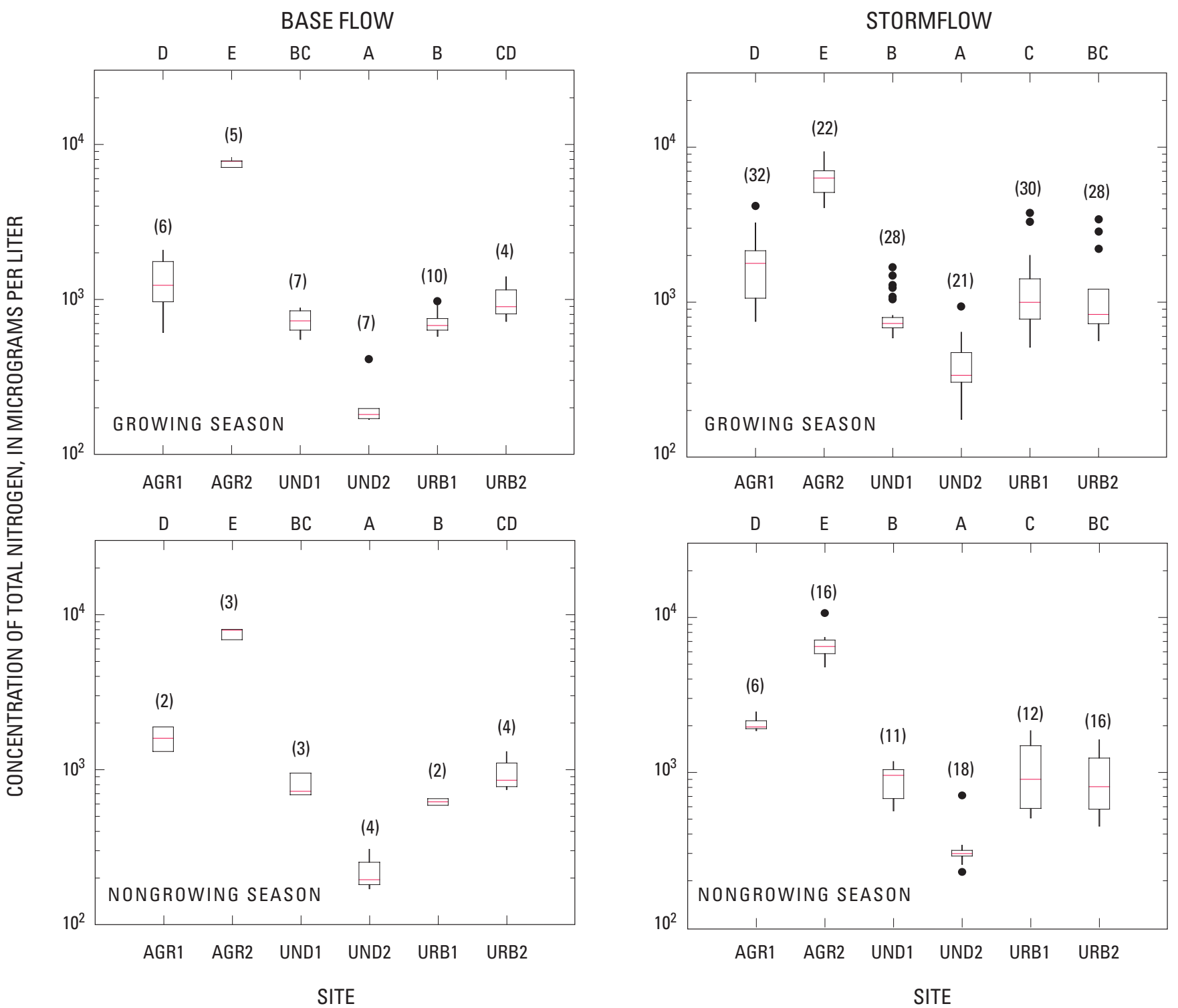

\section{EXPLANATION}

(13) Number of observations

- Outlier data value more than

1.5 times the interquartile range outside the quartile

90th percentile

75th percentile

Median

25th percentile

10th percentile
A,B-Differing letters indicate significant differences in mean values, according to the Tukey multiple-comparison test

MONITORING SITES

Agricultural

AGR1, Blacks Creek near Chesterfield, New Jersey AGR2, Alloway Creek near Watson Corner, New Jersey Undeveloped

UND1, Lahaway Creek Tributary near Prospertown, New Jersey UND2, Gravelly Run at Laurel Lake, New Jersey

Urban

URB1, Cooper River at Route 561 at Haddonfield, New Jersey URB2, South Branch Big Timber Creek Tributary at Grenloch, New Jersey

Figure 11. Distributions of total nitrogen concentrations in unfiltered water samples collected during base flow and stormflow in the growing and nongrowing seasons at monitoring sites in the lower Delaware River Basin, New Jersey, 2002-07. 


\section{BASE FLOW}
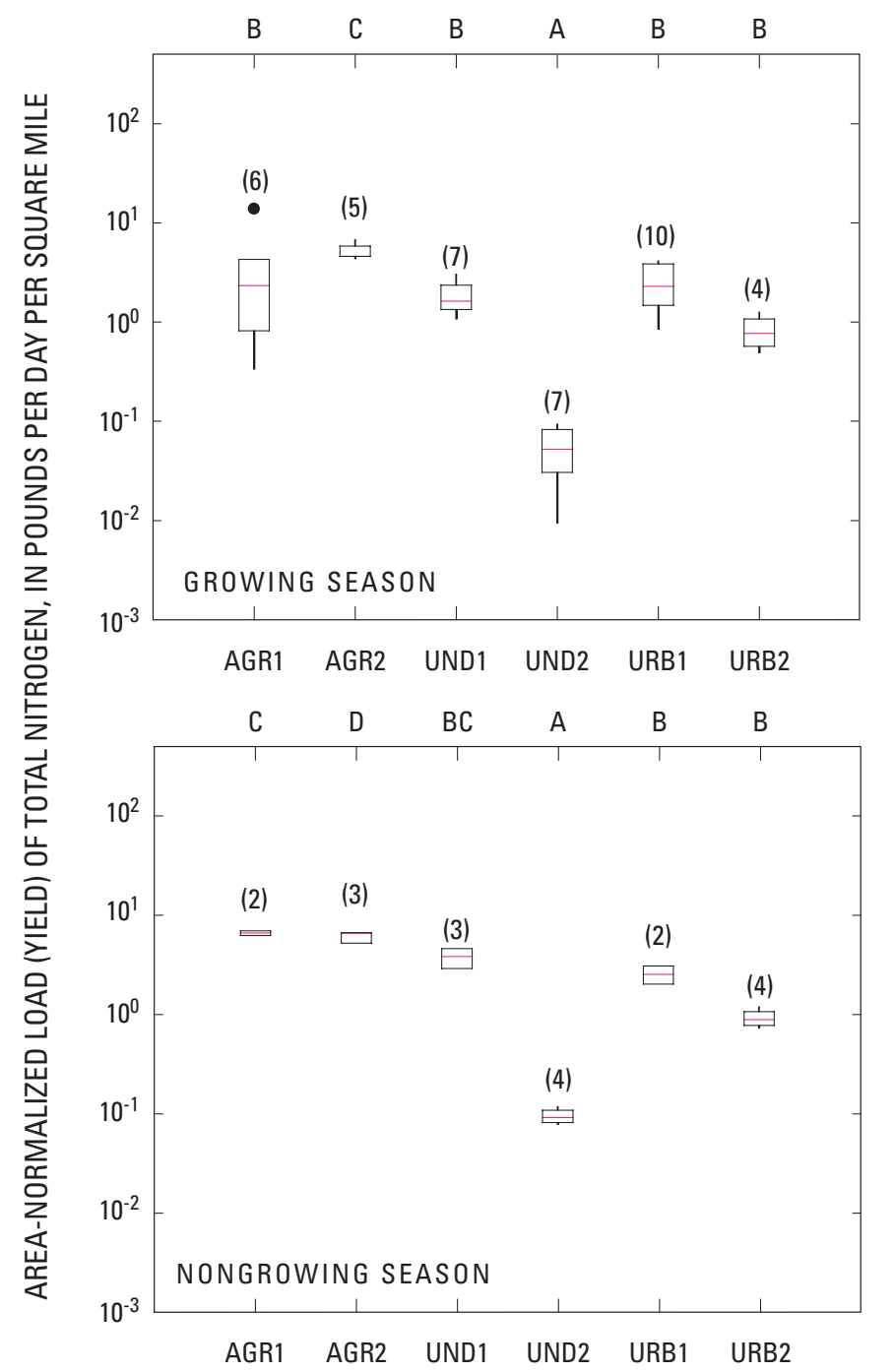

SITE
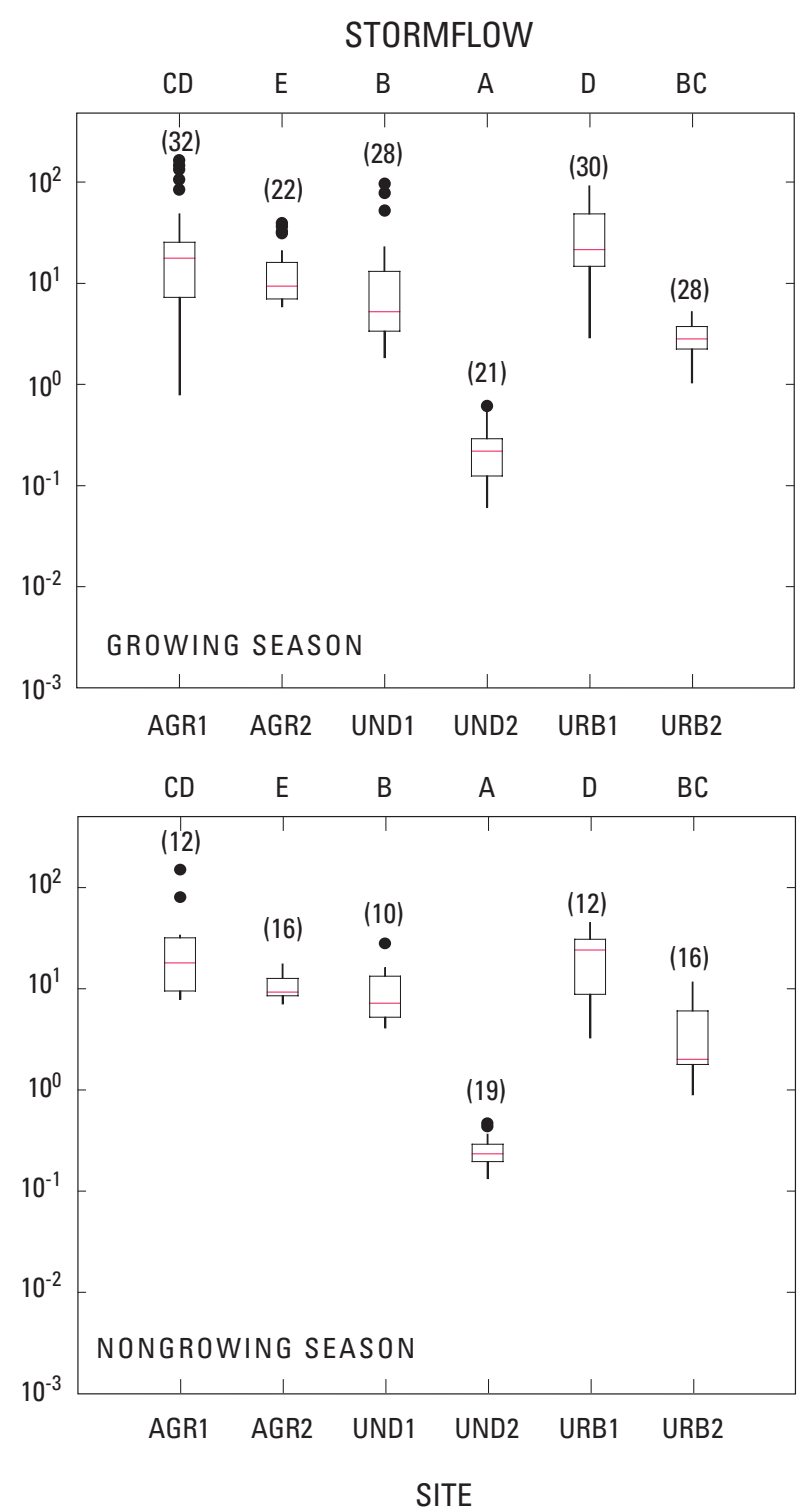

\section{EXPLANATION}

(13) Number of observations

- Outlier data value more than 1.5 times the interquartile range outside the quartile

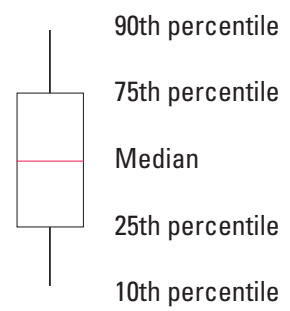

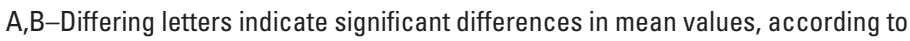
the Tukey multiple-comparison test

MONITORING SITES

Agricultural

AGR1, Blacks Creek near Chesterfield, New Jersey AGR2, Alloway Creek near Watson Corner, New Jersey Undeveloped

UND1, Lahaway Creek Tributary near Prospertown, New Jersey UND2, Gravelly Run at Laurel Lake, New Jersey

Urban

URB1, Cooper River at Route 561 at Haddonfield, New Jersey URB2, South Branch Big Timber Creek Tributary at Grenloch, New Jersey

Figure 12. Distributions of area-normalized loads (yields) of total nitrogen in unfiltered water samples collected during base flow and stormflow in the growing and nongrowing seasons at monitoring sites in the lower Delaware River Basin, New Jersey, 2002-07. 
BASE FLOW

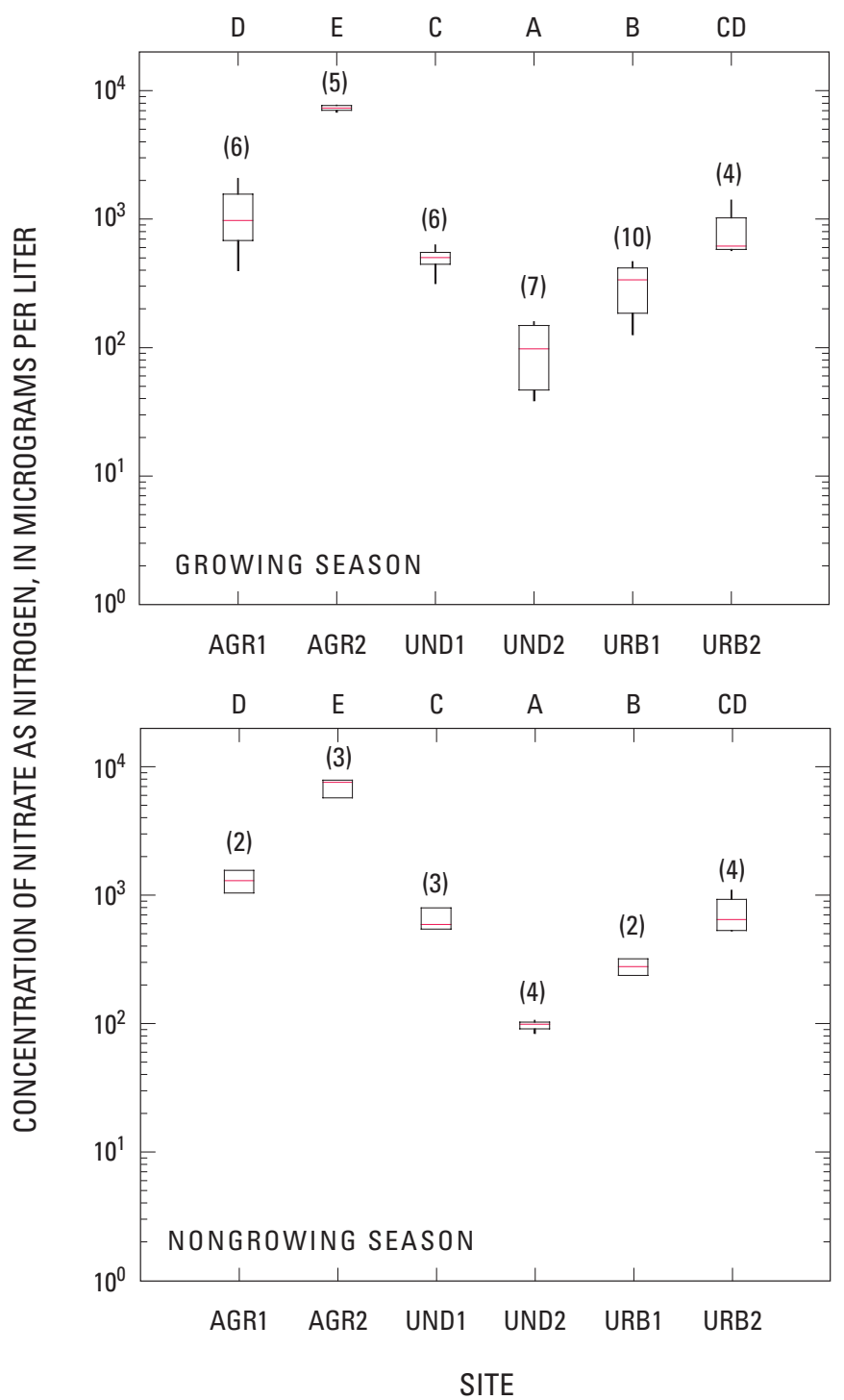

STORMFLOW
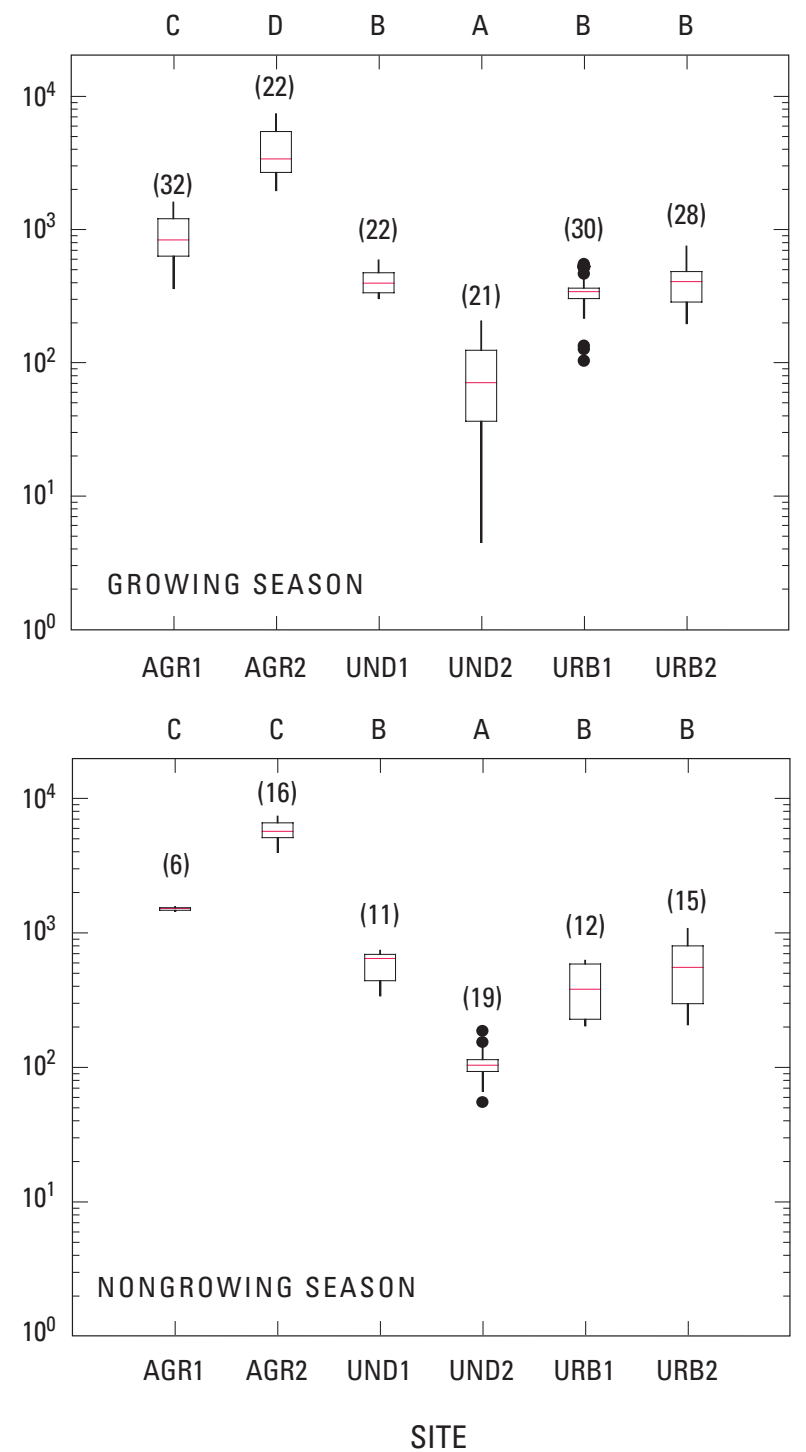

\section{EXPLANATION}

(13) Number of observations

- Outlier data value more than 1.5 times the interquartile range outside the quartile

90th percentile

75th percentile

Median

25th percentile

10th percentile

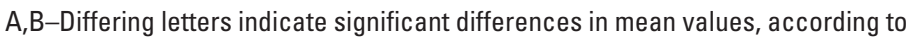
the Tukey multiple-comparison test

MONITORING SITES

Agricultural

AGR1, Blacks Creek near Chesterfield, New Jersey AGR2, Alloway Creek near Watson Corner, New Jersey Undeveloped

UND1, Lahaway Creek Tributary near Prospertown, New Jersey UND2, Gravelly Run at Laurel Lake, New Jersey

Urban

URB1, Cooper River at Route 561 at Haddonfield, New Jersey URB2, South Branch Big Timber Creek Tributary at Grenloch, New Jersey

Figure 13. Distributions of nitrate concentrations in unfiltered water samples collected during base flow and stormflow in the growing and nongrowing seasons at monitoring sites in the lower Delaware River Basin, New Jersey, 2002-07. 


\section{BASE FLOW}
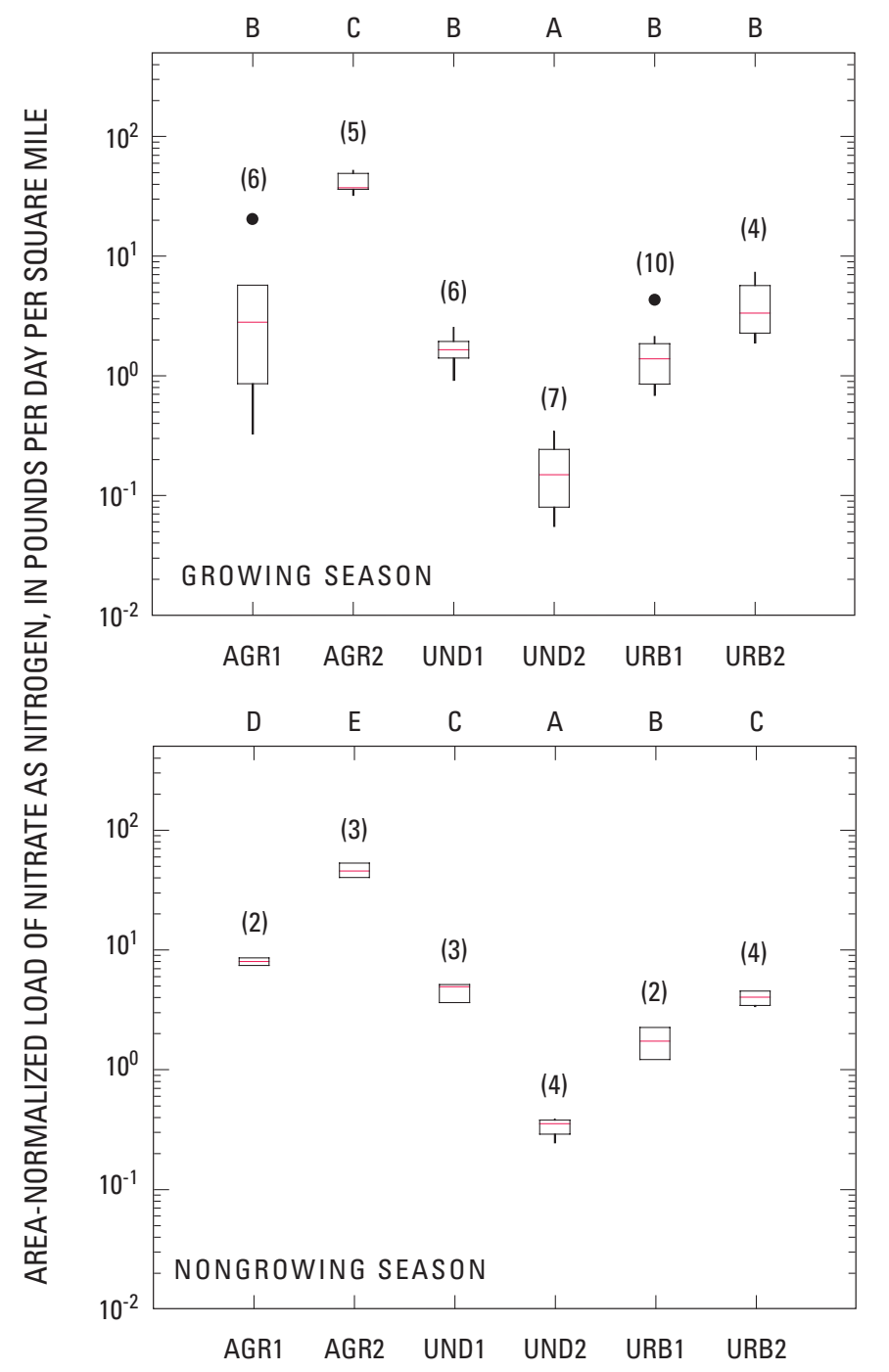

SITE
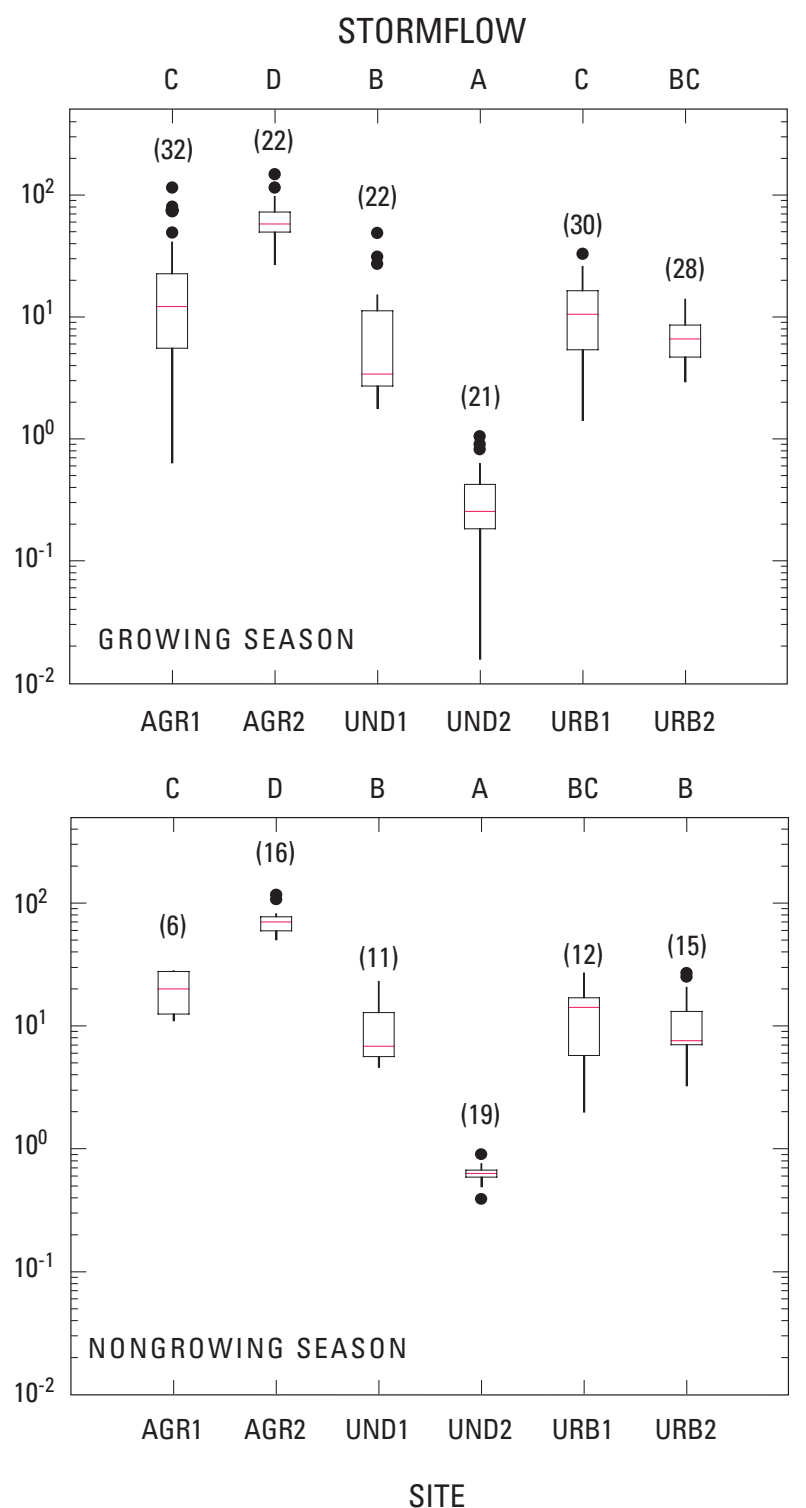

\section{EXPLANATION}

(13) Number of observations

- Outlier data value more than 1.5 times the interquartile range outside the quartile

90th percentile

75th percentile

Median

25th percentile

10th percentile
A,B-Differing letters indicate significant differences in mean values, according to the Tukey multiple-comparison test

MONITORING SITES

Agricultural

AGR1, Blacks Creek near Chesterfield, New Jersey Undeveloped AGR2, Alloway Creek near Watson Corner, New Jersey

UND1, Lahaway Creek Tributary near Prospertown, New Jersey UND2, Gravelly Run at Laurel Lake, New Jersey

Urban

URB1, Cooper River at Route 561 at Haddonfield, New Jersey URB2, South Branch Big Timber Creek Tributary at Grenloch, New Jersey

Figure 14. Distributions of area-normalized loads (yields) of nitrate in unfiltered water samples collected during base flow and stormflow in the growing and nongrowing seasons at monitoring sites in the lower Delaware River Basin, New Jersey, $2002-07$. 
Yields at UND2 are significantly lower than at any other site. As with nitrate concentrations, nitrate yields at UND1 are more similar to those for the urban sites than to those for the other undeveloped site.

\section{Ammonia}

Ammonia $\left(\mathrm{NH}_{3}\right)$ is the most reduced nitrogen species found in surface water and persists only under anaerobic (reducing) conditions (National Research Council, 1979). Concentrations are expressed as milligrams per liter $\mathrm{NH}_{3}$ as $\mathrm{N}$. Application of ammonium-based fertilizers and effluents from sewage-treatment plants can contribute substantial amounts of ammonia to surface water, as is the case for the Kansas River (Rasmussen and Christensen, 2005). Untreated domestic wastewater typically contains 12 to $50 \mathrm{mg} / \mathrm{L} \mathrm{NH}_{3}$ - as N (Metcalf and Eddy Inc., 1979). Bacterial decomposition of organic matter under reducing (anaerobic) conditions in bottom sediments also contributes ammonia to surface water.

Ammonia in sufficiently high concentrations is toxic to most aquatic organisms. Toxicity levels are affected by dissolved oxygen concentrations, temperature, $\mathrm{pH}$, previous acclimation to ammonia, carbon dioxide concentrations, and the presence of other toxic compounds (U.S. Environmental Protection Agency, 1991). Ammonia did not constitute a substantial percentage of the total nitrogen concentrations or loads for the six streams; typically, ammonia constituted 3 to 6 percent. Box plots in figure 15 show that there is no clear relation between land-use patterns and ammonia concentration. Perhaps most notably, concentrations in samples from URB1 during base flow in the growing and nongrowing seasons were significantly higher than those from any other site. During stormflow, site UND2 had significantly lower concentrations of ammonia than either agricultural or urban site, and ammonia concentrations for UND2 could not be distinguished from those in samples from the other undeveloped site (UND1).

Yields at site URB1 were significantly higher than those at any other site during the growing season, but yields were homogeneous among all sites during base flow in the nongrowing season (fig. 16). As with concentrations, yields of ammonia for UND2 were lower than those for any other site.

Concentrations and loads of ammonia appear to be elevated in both agricultural and urban land-use areas, compared with concentrations and loads for background sites (undeveloped sites UDN1 and UND2) in the lower Delaware River Basin. It is not clear from the data collected which landuse category contributed most to the ammonia loads, but for all sites, ammonia represents only a few percent of the total concentrations and yields of nitrogen.

\section{Organic Nitrogen}

Concentrations of organic nitrogen are calculated as the difference between total nitrogen and the sum of the concentrations of all inorganic nitrogen species (nitrate, nitrite, and ammonia). In water samples collected from the six sites in the lower Delaware River Basin organic nitrogen constituted a substantial fraction of the total nitrogen concentrations and loads (10-35 percent).

Sources of organic nitrogen in surface water include soil mineralization, algal and other aquatic plant growth, terrestrial plant residue, animal wastes, and decomposition of plant material. In surface water, organic nitrogen is present in amino acids, proteins, nucleic acids, and other biological macromolecules.

The molecular formula of algal protoplasm (Redfield stoichiometry) can be used to approximate the nitrogen content of organic matter (Redfield, 1958):

$$
\begin{aligned}
& 106 \mathrm{CO}_{2}+16 \mathrm{NO}_{3}-+\mathrm{HPO}_{4}{ }^{2-}+122 \mathrm{H}_{2} \mathrm{O}+18 \mathrm{H}^{+} \rightarrow> \\
& \mathrm{C}_{106} \mathrm{H}_{263} \mathrm{O}_{110} \mathrm{~N}_{16} \mathrm{P}_{1} \text {. }
\end{aligned}
$$

Thus, on a mass basis, organic matter in streams contains approximately 6.3 percent nitrogen. The sources, properties, and bioavailability of organic nitrogen in a stream are dependent upon the properties of suspended and dissolved organic matter. Sources of organic carbon can be classified as either autochthonous, contributed by in-stream processes such as decaying algal, plant, and animal tissues, or allochthonous, such as organic material in runoff from point and nonpoint sources (Gondar and others, 2008).

Organic nitrogen concentrations (fig. 17) were significantly higher in samples from site AGR2 collected during base flow than in those from the two undeveloped and the two urban sites but statistically indistinguishable from those in samples from site AGR1. There was no significant difference among concentrations in samples from undeveloped and urban sites. Yields of organic nitrogen did not have a clearly evident relation to land use; however, UND2, the least developed site, had significantly lower concentrations than all other sites during stormflow. Although site UND2 had the lowest organic nitrogen yield of all sites (fig. 18), the Tukey test did not distinguish among the sites with respect to land-use patterns.

\section{Phosphorus}

Phosphorus is an essential element for all organisms, and as a result, any excessive loads of phosphorus to surface water can lead to eutrophication. Phosphorus can be present in organic matter; however, generally the highest concentrations are present in inorganic forms (orthophosphate and polyphosphates). Application of inorganic fertilizers is one of the most important sources of phosphorus in surface waters (Mueller and others, 1995).

It has been estimated that about 80 percent of lake and reservoir eutrophication is the result of excess phosphorus. About 10 percent of lake and reservoir eutrophication is related to nitrogen, and the other 10 percent of lake and reservoir eutrophication is related to other factors (Zhao, 2004). Although phosphorus in natural water systems tends to be associated with the solid phase, adsorbed to sediment and 
BASE FLOW

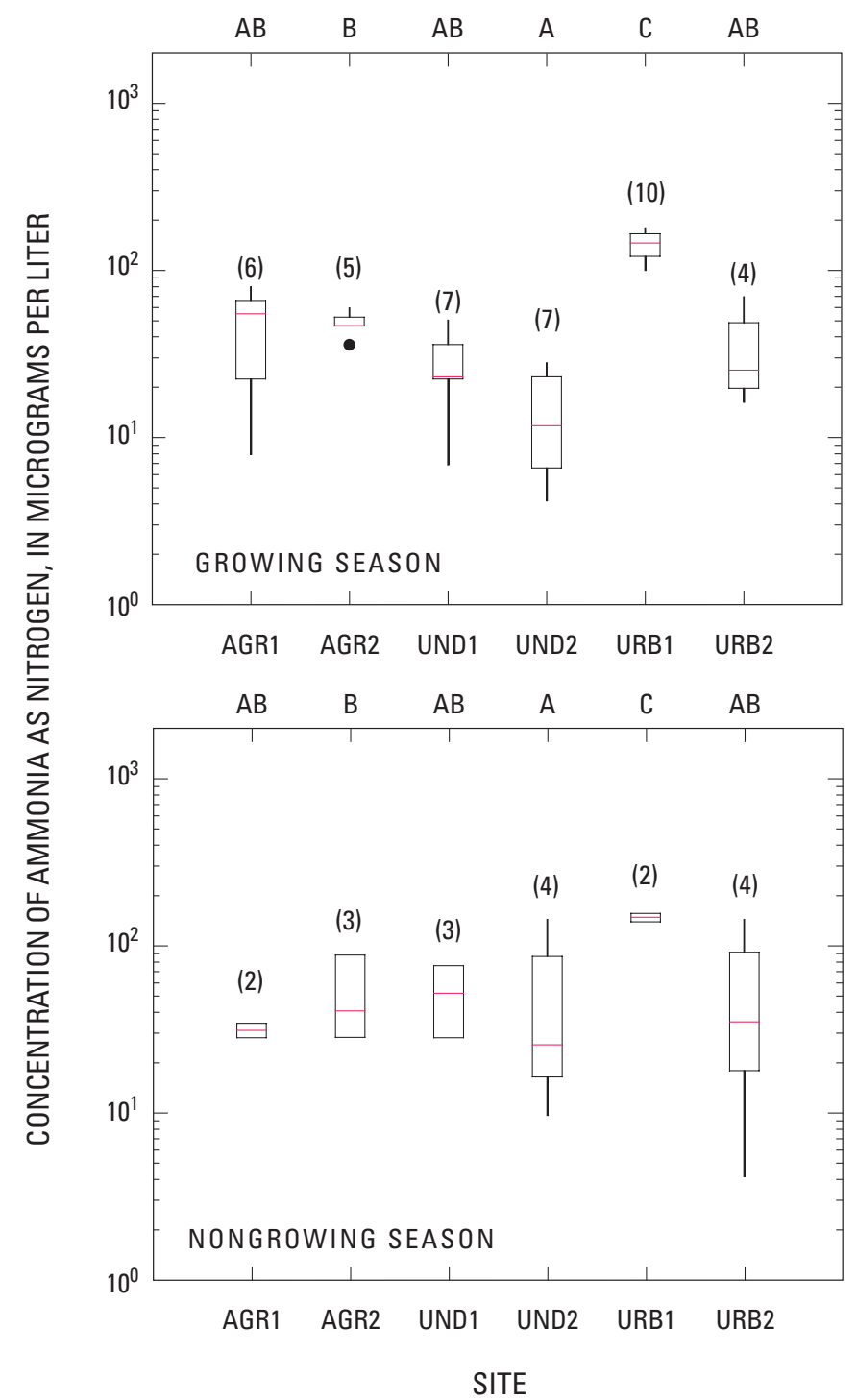

STORMFLOW
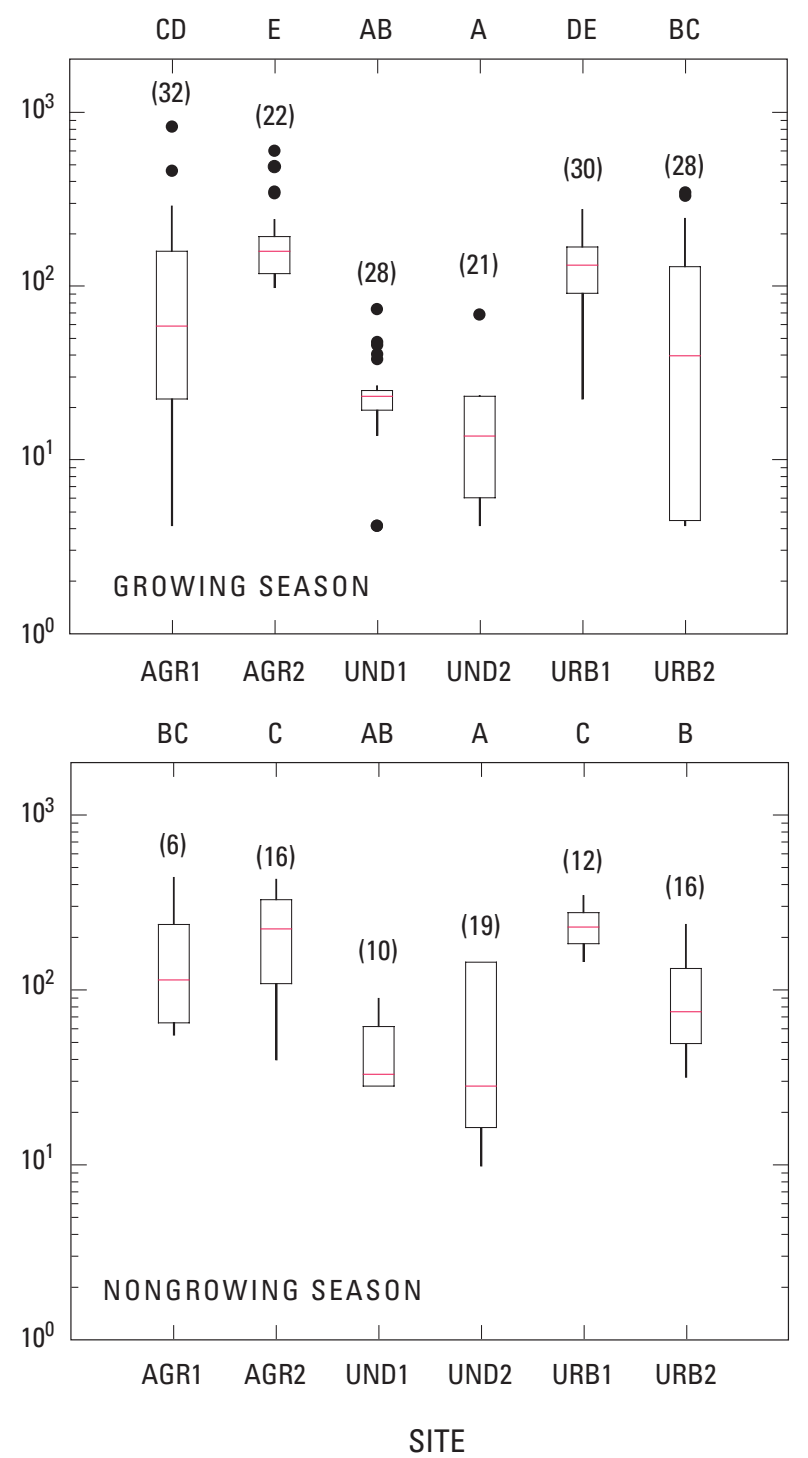

\section{EXPLANATION}
(13) Number of observations
- Outlier data value more than 1.5 times the interquartile range outside the quartile
90th percentile
75th percentile
Median
25th percentile
10th percentile

\author{
A,B-Differing letters indicate significant differences in mean values, according to \\ the Tukey multiple-comparison test \\ MONITORING SITES \\ Agricultural \\ AGR1, Blacks Creek near Chesterfield, New Jersey \\ Undeveloped \\ AGR2, Alloway Creek near Watson Corner, New Jersey \\ UND1, Lahaway Creek Tributary near Prospertown, New Jersey \\ UND2, Gravelly Run at Laurel Lake, New Jersey \\ Urban \\ URB1, Cooper River at Route 561 at Haddonfield, New Jersey \\ URB2, South Branch Big Timber Creek Tributary at Grenloch, New Jersey
}

Figure 15. Distributions of ammonia concentrations in unfiltered water samples collected during base flow and stormflow in the growing and nongrowing seasons at monitoring sites in the lower Delaware River Basin, New Jersey, 2002-07. 
BASE FLOW

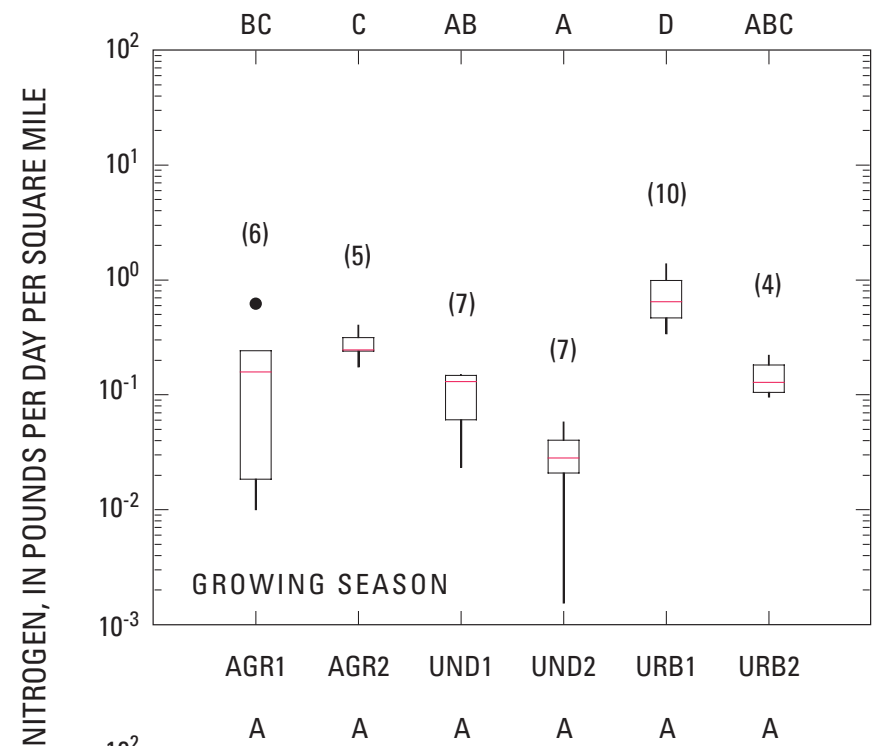

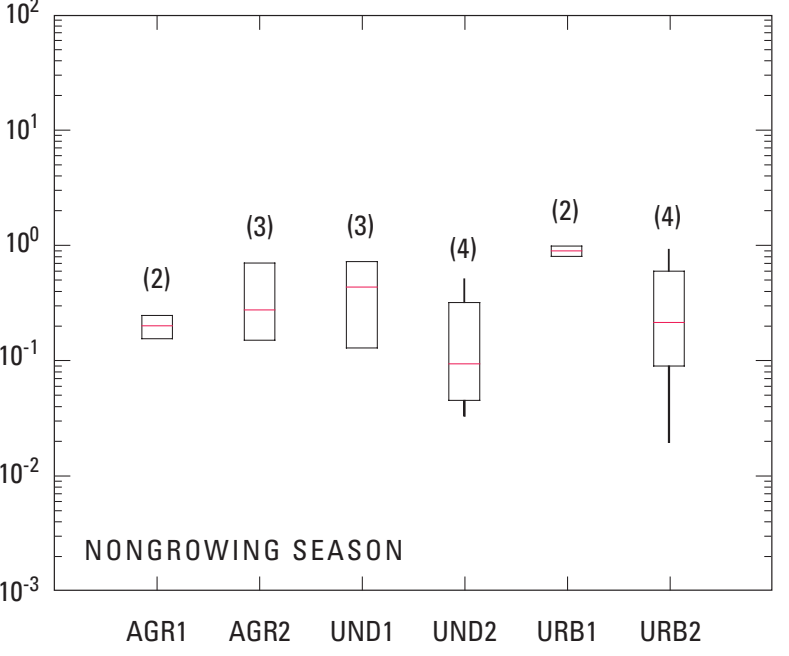

SITE
STORMFLOW
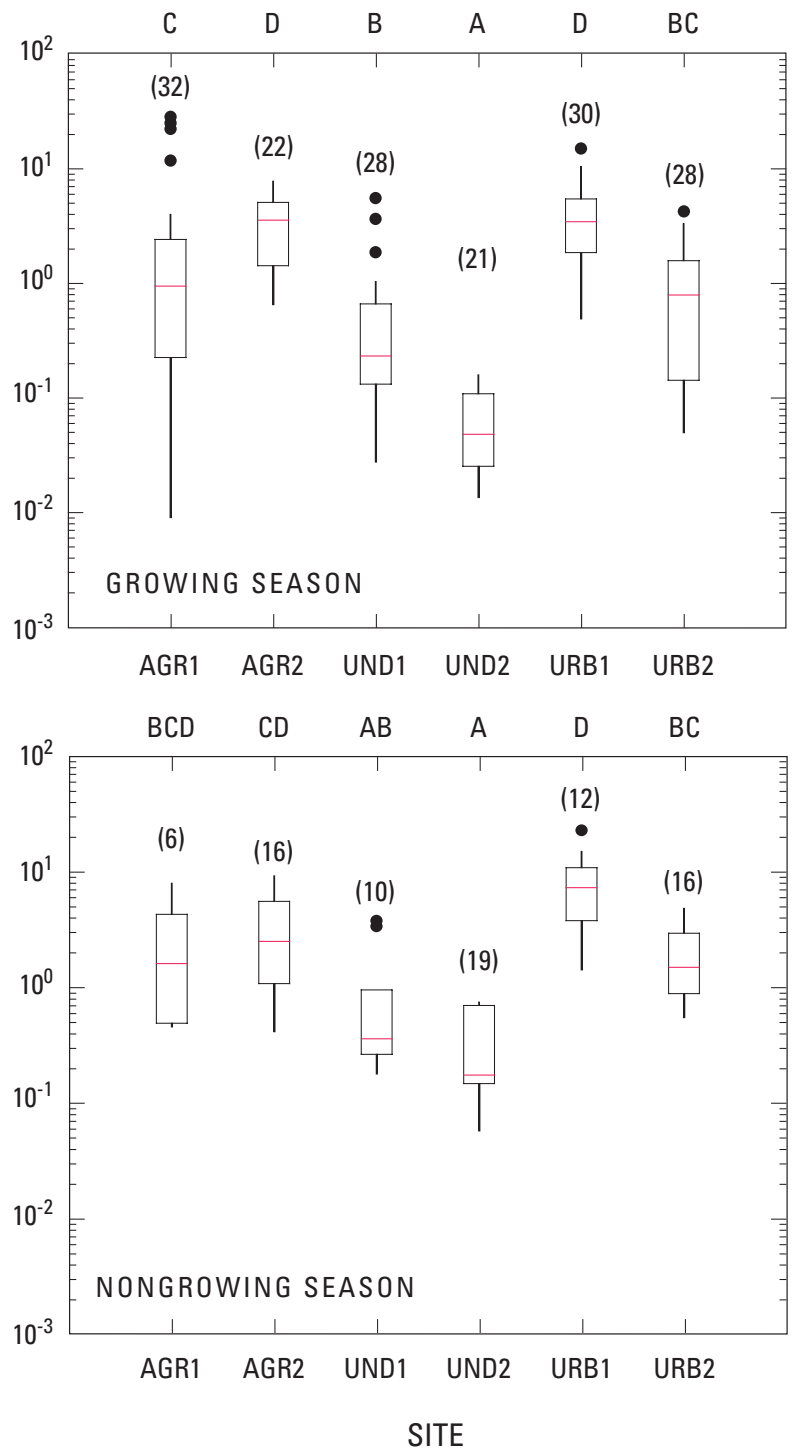

\section{EXPLANATION}

(13) Number of observations

- Outlier data value more than

1.5 times the interquartile range outside the quartile

90th percentile

75th percentile

Median

25th percentile

10th percentile
A,B-Differing letters indicate significant differences in mean values, according to the Tukey multiple-comparison test

MONITORING SITES

Agricultural

AGR1, Blacks Creek near Chesterfield, New Jersey AGR2, Alloway Creek near Watson Corner, New Jersey Undeveloped

UND1, Lahaway Creek Tributary near Prospertown, New Jersey UND2, Gravelly Run at Laurel Lake, New Jersey

Urban

URB1, Cooper River at Route 561 at Haddonfield, New Jersey URB2, South Branch Big Timber Creek Tributary at Grenloch, New Jersey

Figure 16. Distributions of area-normalized loads (yields) of ammonia in unfiltered water samples collected during base flow and stormflow in the growing and nongrowing seasons at monitoring sites in the lower Delaware River Basin, New Jersey, 2002-07. 


\section{BASE FLOW}

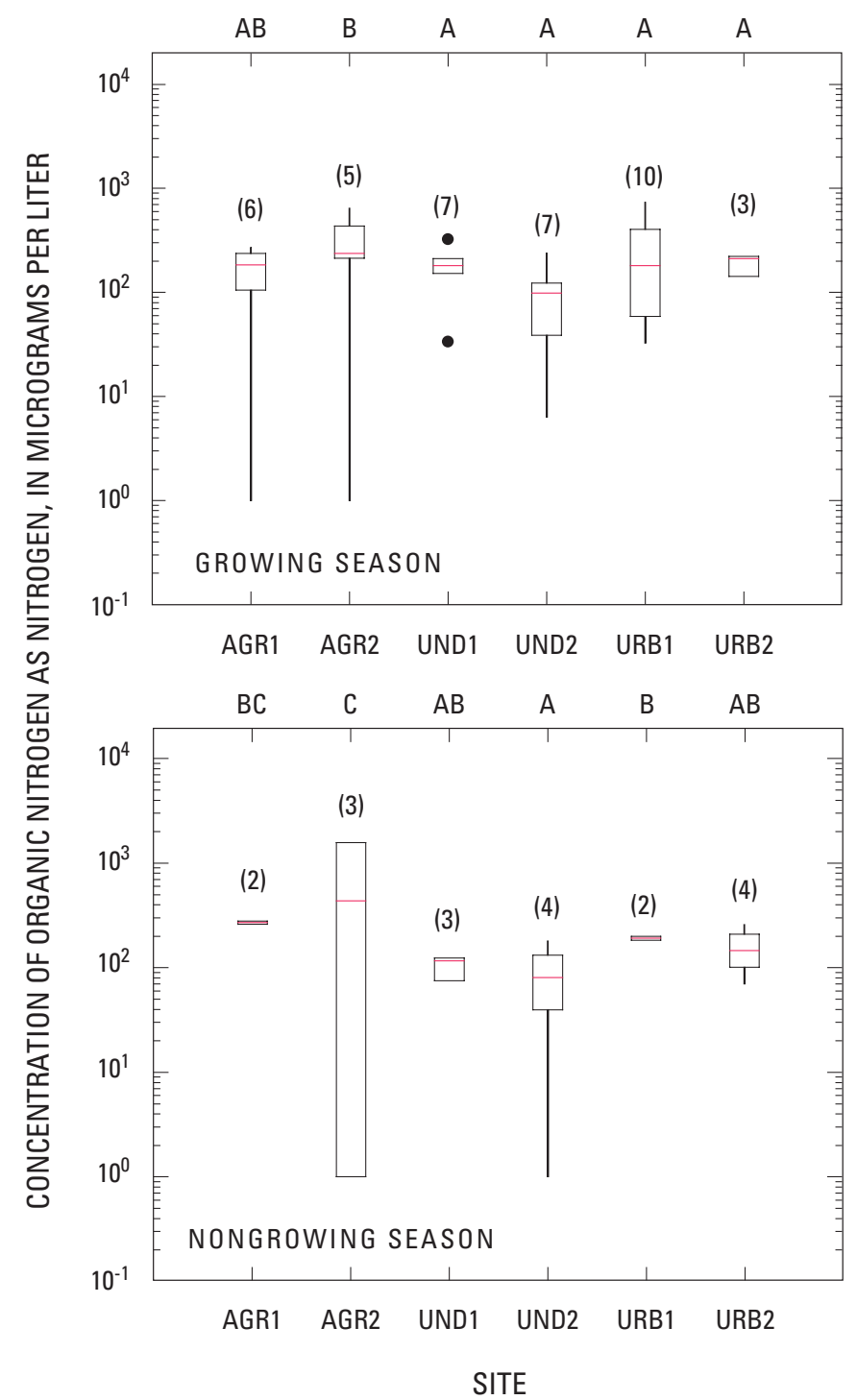

STORMFLOW
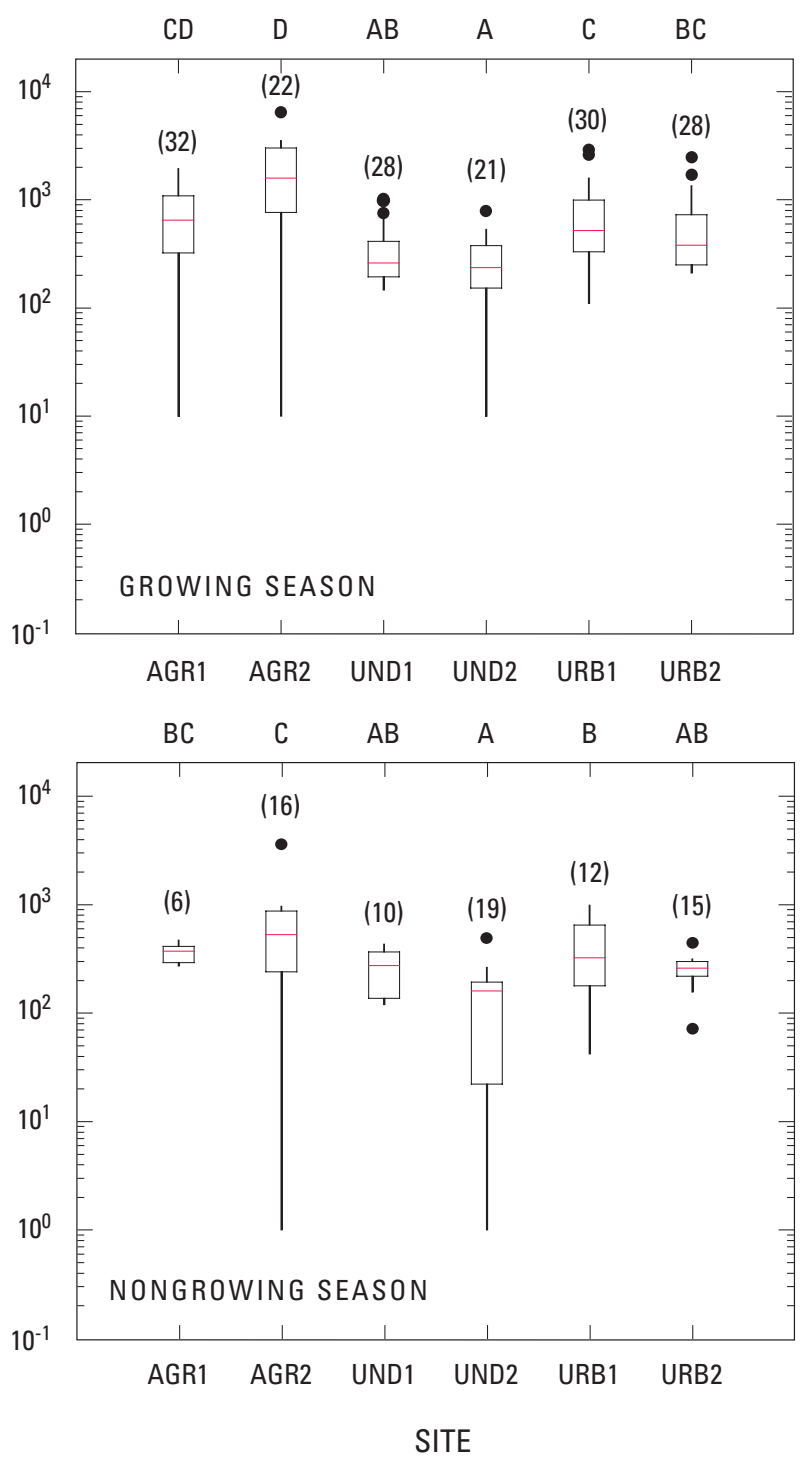

\section{EXPLANATION}

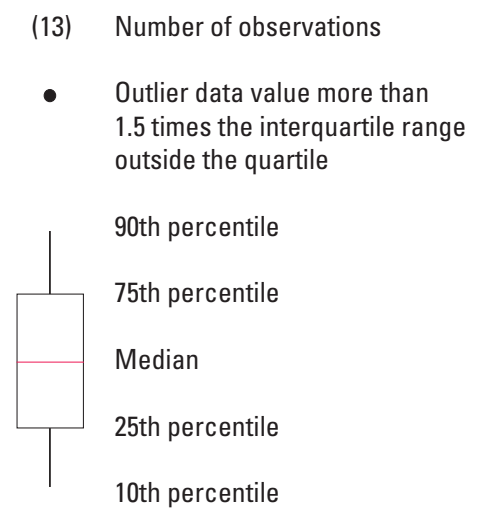

A,B-Differing letters indicate significant differences in mean values, according to the Tukey multiple-comparison test

\section{MONITORING SITES}

Agricultural

AGR1, Blacks Creek near Chesterfield, New Jersey AGR2, Alloway Creek near Watson Corner, New Jersey Undeveloped

UND1, Lahaway Creek Tributary near Prospertown, New Jersey UND2, Gravelly Run at Laurel Lake, New Jersey

Urban

URB1, Cooper River at Route 561 at Haddonfield, New Jersey URB2, South Branch Big Timber Creek Tributary at Grenloch, New Jersey

Figure 17. Distributions of organic nitrogen concentrations in unfiltered water samples collected during base flow and stormflow in the growing and nongrowing seasons at monitoring sites in the lower Delaware River Basin, New Jersey, 2002-07. 
BASE FLOW

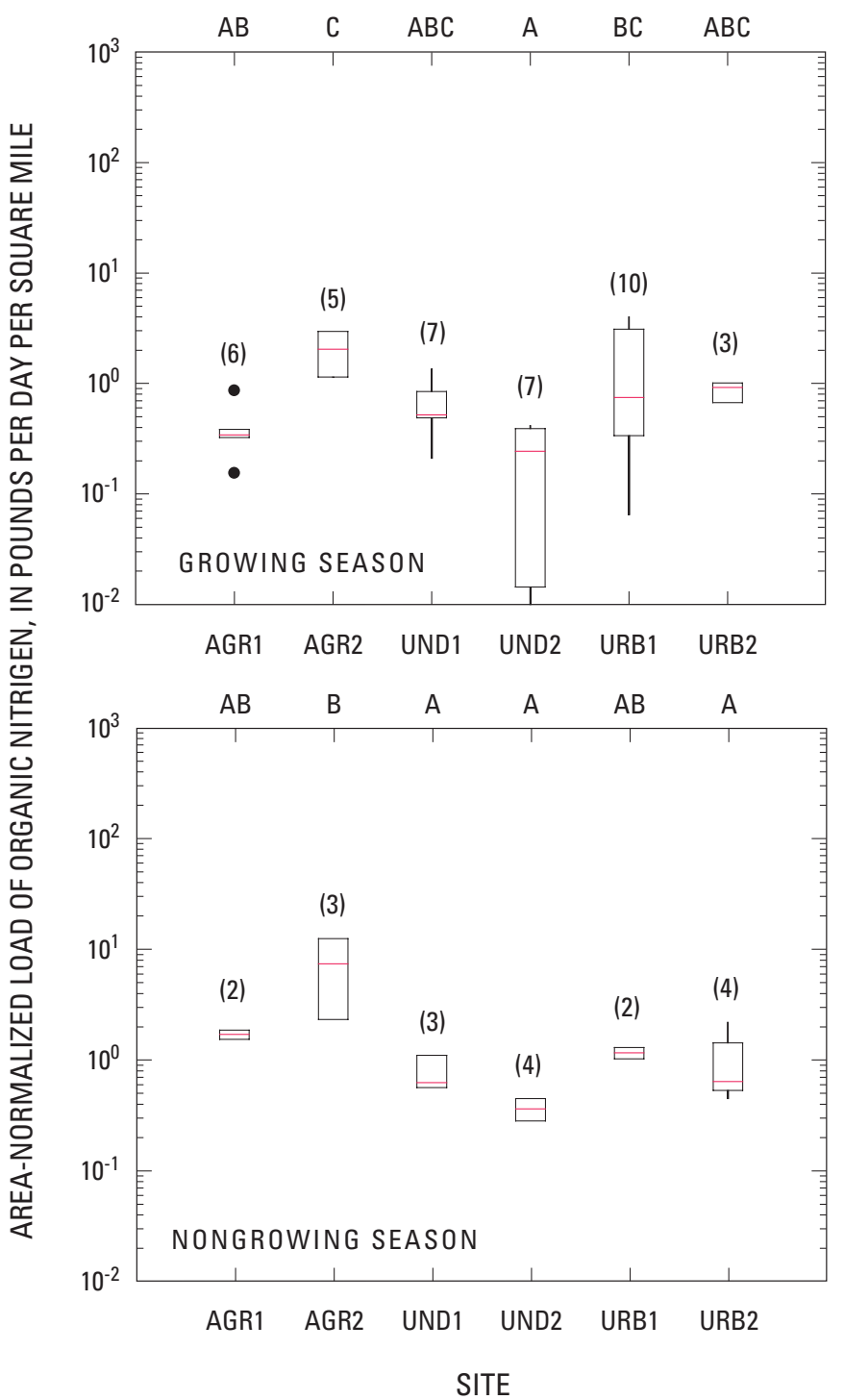

STORMFLOW
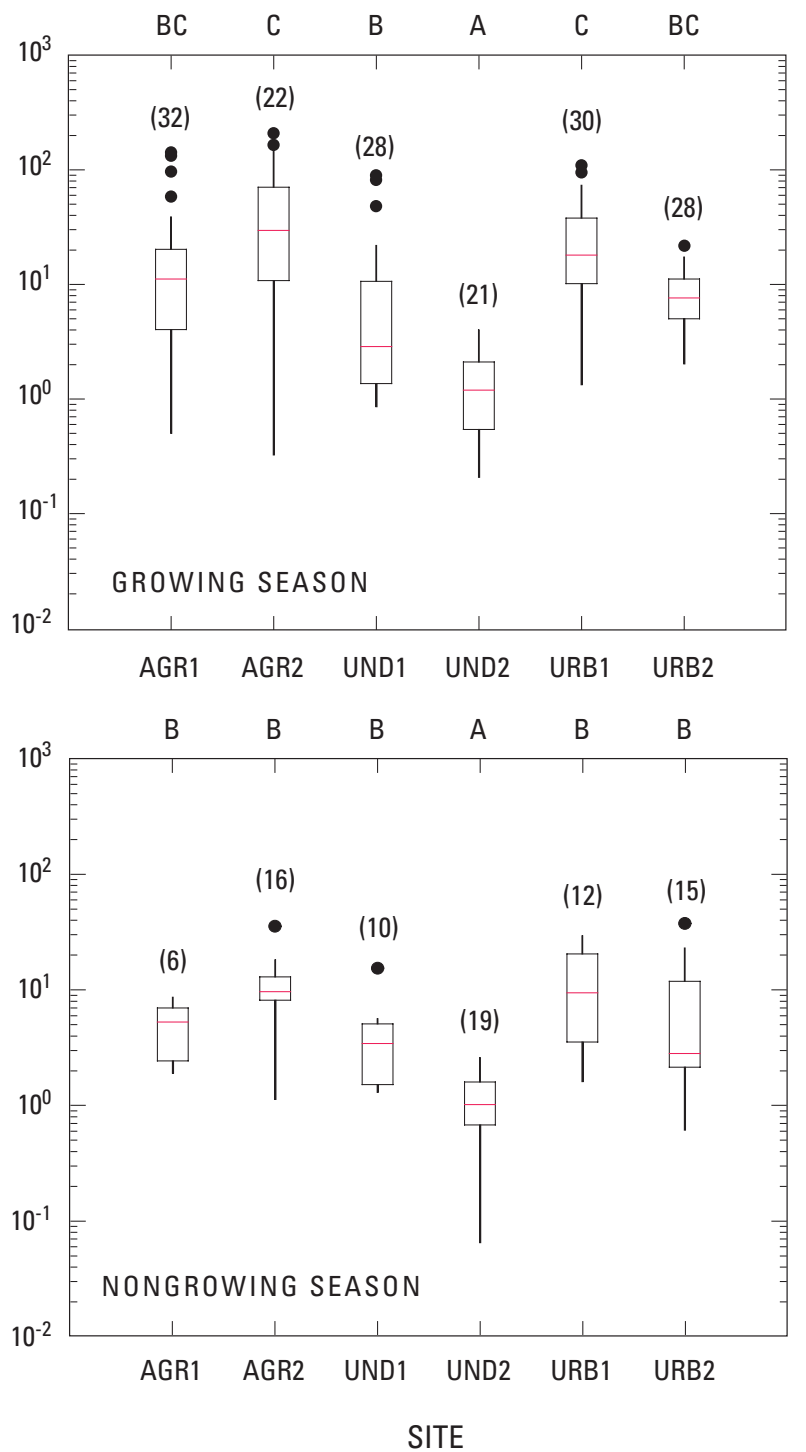

\section{EXPLANATION}

(13) Number of observations

- Outlier data value more than

1.5 times the interquartile range outside the quartile

90th percentile

75th percentile

Median

25th percentile

10th percentile
A,B-Differing letters indicate significant differences in mean values, according to the Tukey multiple-comparison test

MONITORING SITES

Agricultural

AGR1, Blacks Creek near Chesterfield, New Jersey AGR2, Alloway Creek near Watson Corner, New Jersey Undeveloped

UND1, Lahaway Creek Tributary near Prospertown, New Jersey UND2, Gravelly Run at Laurel Lake, New Jersey

Urban

URB1, Cooper River at Route 561 at Haddonfield, New Jersey URB2, South Branch Big Timber Creek Tributary at Grenloch, New Jersey

Figure 18. Distributions of area-normalized loads (yields) of organic nitrogen in unfiltered water samples collected during base flow and stormflow in the growing and nongrowing seasons at monitoring sites in the lower Delaware River Basin, New Jersey, 2002-07. 
particulates, substantial mobility of phosphorus in groundwater has been demonstrated (Walter and others, 1999). Therefore, some dissolved phosphorus is expected in base flow (supplied by groundwater), whereas stormflow containing phosphorus-laden sediments is expected to have higher total phosphorus concentrations.

Phosphorus is introduced into lakes and streams from point and nonpoint sources. Nonpoint sources include natural decomposition of rocks and minerals, stormwater runoff, agricultural runoff, erosion and sedimentation, atmospheric deposition, and direct input by animals/wildlife. Point sources may include wastewater-treatment plants and permitted industrial discharges. In general, concentrations of phosphorus from nonpoint sources typically are significantly higher than those from point sources.

Because of its important role in the growth of algae and other aquatic plants, the trophic state of a freshwater body can be characterized by the phosphorus concentration (table 1). Lakes with total phosphorus concentrations less than $0.010 \mathrm{mg} / \mathrm{L}$ are classified as oligotrophic. Lakes with phosphorus concentrations from 0.010 to $0.035 \mathrm{mg} / \mathrm{L}$ are indicative of mesotrophic lakes, and lakes with phosphorus concentrations exceeding $0.035 \mathrm{mg} / \mathrm{L}$ are classified as eutrophic (Mueller and Helsel, 1999).

\section{Total Phosphorus}

Concentrations of total phosphorus in base flow were generally lower than those in stormflow (fig. 19). This was expected because most phosphorus in a natural water system is transported in the solid phase (sediment, suspended sediment, and colloidal matter). There is a subtle relation between total phosphorus concentration and land use during base flow. The six sites can be grouped into two categories on the basis of mean (or median) base-flow total phosphorus concentrations. The two agricultural sites and one urban site (Cooper River, URB1) typically had base-flow concentrations of 0.4 to $0.6 \mathrm{mg} / \mathrm{L}$ of total phosphorus as $\mathrm{P}$, and the two undeveloped sites and one urban site (Big Timber Creek, URB2) had concentrations of 0.02 to $0.08 \mathrm{mg} / \mathrm{L}$, about an order of magnitude lower. Higher concentrations of phosphorus for the agricultural sites compared to those for the undeveloped sites can be attributed to the well-characterized effect of agricultural land use. The difference in base-flow total phosphorus concentrations between the two urban streams is probably due to the long-term historical discharge of poorly treated domestic wastewater into the Cooper River but not into Big Timber Creek. Under stormflow conditions the same three streams (Cooper River, Alloway Creek, and Blacks Creek) had significantly higher concentrations of total phosphorus than the other streams.

Yields of total phosphorus during base flow are not clearly related to land use. The yield in base-flow samples from site URB1 was significantly greater than that for URB2, analogous to the relation for total phosphorus concentration. During stormflow, yields of total phosphorus were lower for the two undeveloped sites than for the urban and agricultural sites during growing and nongrowing seasons. The highest median yields were determined for URB1, which had significantly greater yields than URB2. It is clear from figures 19 and 20 that high concentrations and yields of total phosphorus are associated with agricultural and urban land-use activities.

\section{Orthophosphate}

Concentrations of orthophosphate during base flow (fig. 21) are statistically indistinguishable among sites and between seasons. The low concentrations (typically $1-3 \mu \mathrm{g} / \mathrm{L}$ as $\mathrm{P}$ ) indicate that orthophosphate is either not mobile or is conservative in the porous media underlying these streams and in the basins, or that there are no substantial sources of orthophosphate to the discharging groundwater (base flow). Concentrations of orthophosphate greater than $1 \mathrm{mg}$ / in surface water are often caused by groundwater (base flow) that contacted phosphate-rich natural deposits. For example, Wilson and others (1999) report concentrations of orthophosphate greater than $1 \mathrm{mg} / \mathrm{L}$ in groundwater discharging to the Tualatin River of northwest Oregon. Efforts to control phosphorus levels in that area of Oregon by decreasing agricultural and domestic wastewater inputs were not successful, and the principal source of phosphorus was found to be phosphatebearing vivianite (hydrated ferrous phosphate). The absence of orthophosphate in base flow (originating from groundwater) for all six streams in this study indicates that mineralogical sources are not substantial.

The stream with the most consistently elevated orthophosphate concentrations was Alloway Creek (AGR2); concentrations were an order of magnitude greater than those of the other streams during the growing and nongrowing seasons. This is most likely due to the presence of livestock in and near the stream. The orthophosphate is probably a biochemical byproduct of the organic phosphorus derived from cattle waste. The orthophosphate concentration for Cooper River (URB2) was sometimes higher than those for the other urban stream and the undeveloped streams, especially during the growing season. The cause for this is unknown.

Yields of orthophosphate for the pristine Gravelly Run (UND2) (fig. 22) tended to be lower than those for the other streams during base flow. Yields among the other streams were statistically indistinguishable. Yields during stormflow varied widely in most streams, making it impossible to statistically differentiate mean values. Yields for Alloway Creek (AGR2) were significantly higher than those of all other streams, and yields for the urban streams-Cooper River and South Branch Big Timber Creek - tended to be higher than those of the undeveloped streams-Lahaway Creek and Gravelly Run.

\section{Ratios of Total Nitrogen to Total Phosphorus}

The ratio of nitrogen to phosphorus in a surface-water body is an indicator of which nutrient is limiting. Phosphoruslimited conditions generally exist when the total-N to total-P 

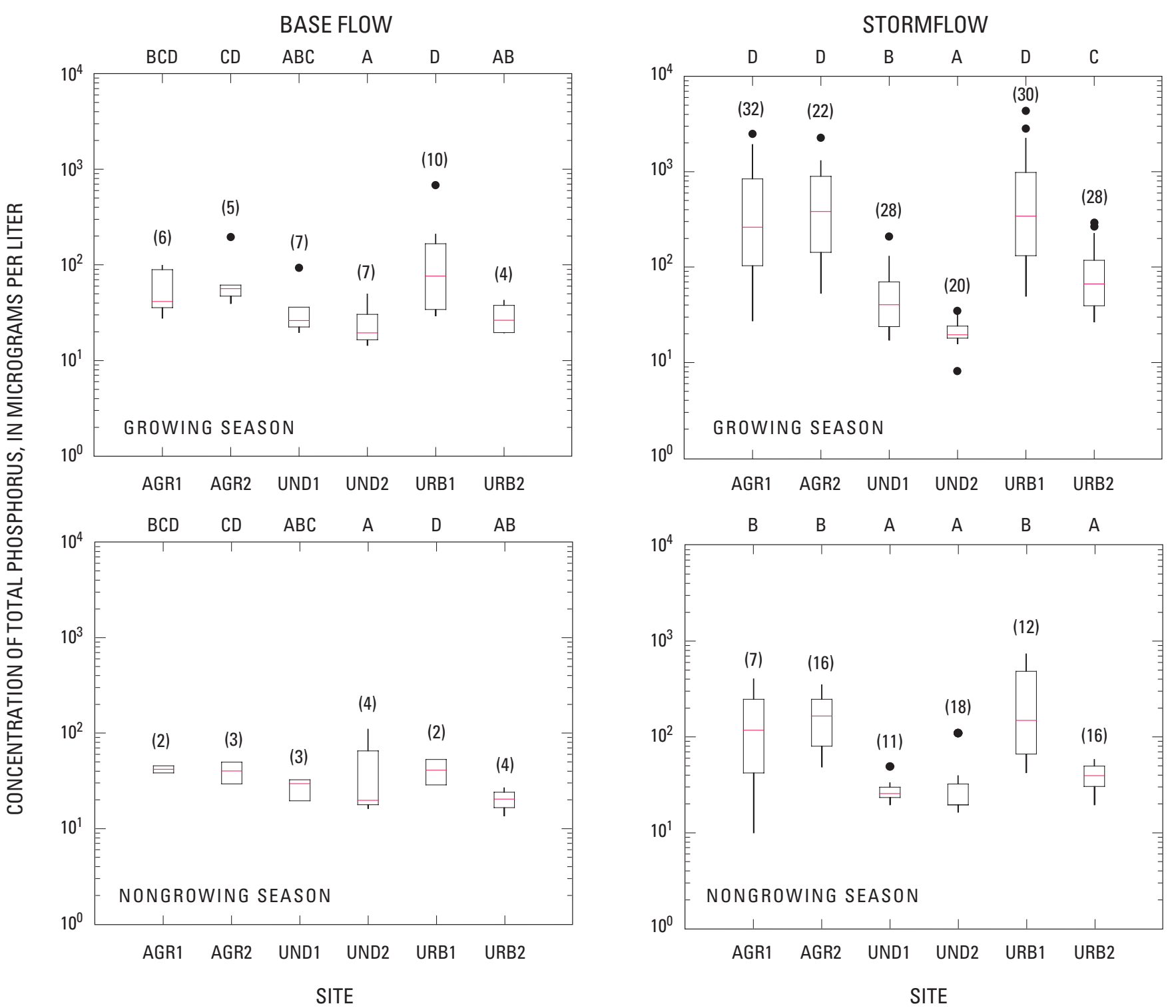

\section{EXPLANATION}

(13) Number of observations

- Outlier data value more than

1.5 times the interquartile range outside the quartile

90th percentile

75th percentile

Median

25th percentile

10th percentile
A,B-Differing letters indicate significant differences in mean values, according to the Tukey multiple-comparison test

MONITORING SITES

Agricultural

AGR1, Blacks Creek near Chesterfield, New Jersey AGR2, Alloway Creek near Watson Corner, New Jersey Undeveloped

UND1, Lahaway Creek Tributary near Prospertown, New Jersey UND2, Gravelly Run at Laurel Lake, New Jersey

Urban

URB1, Cooper River at Route 561 at Haddonfield, New Jersey URB2, South Branch Big Timber Creek Tributary at Grenloch, New Jersey

Figure 19. Distributions of total phosphorus concentrations in unfiltered water samples collected during base flow and stormflow in the growing and nongrowing seasons at monitoring sites in the lower Delaware River Basin, New Jersey, 2002-07. 
BASE FLOW

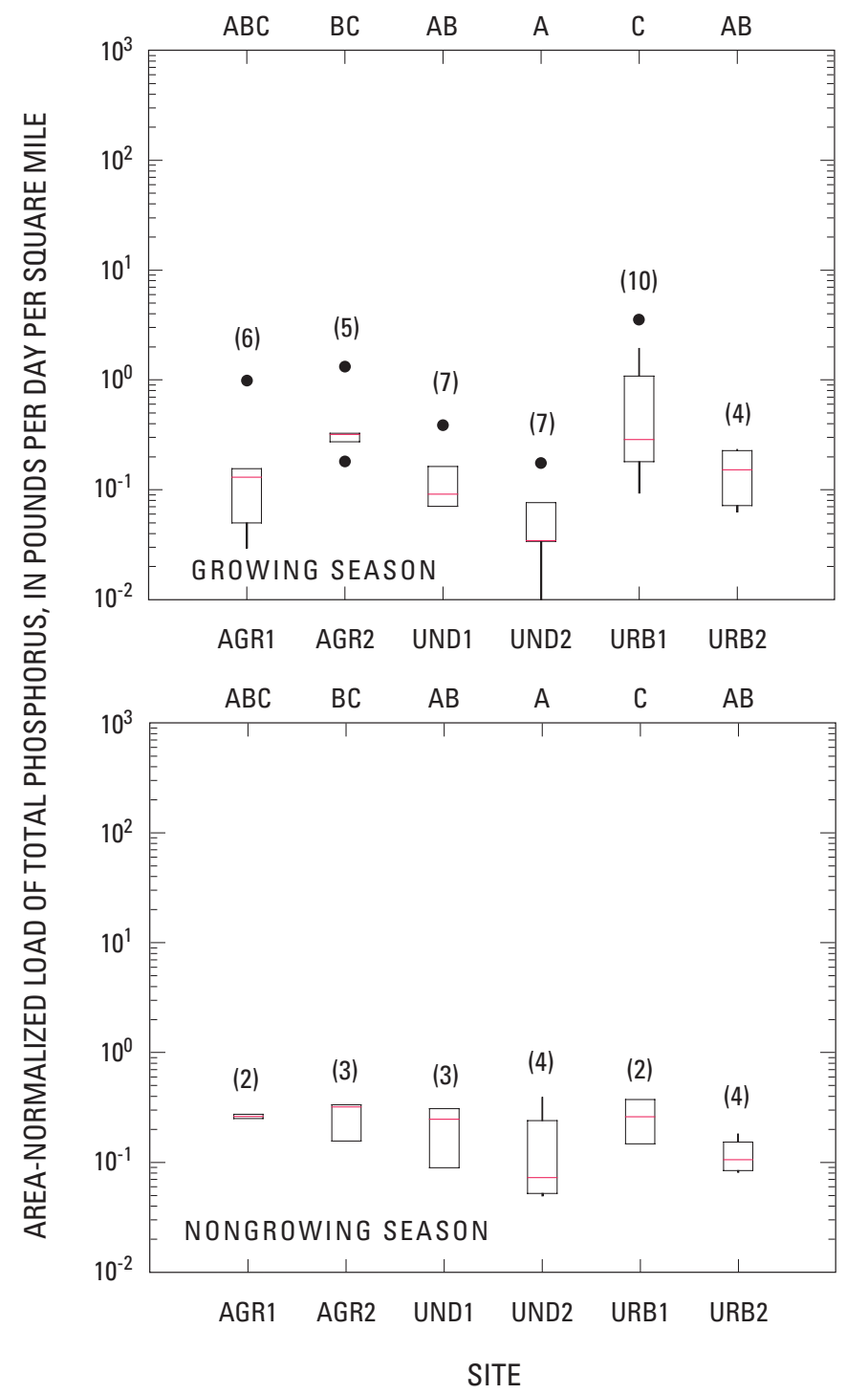

STORMFLOW
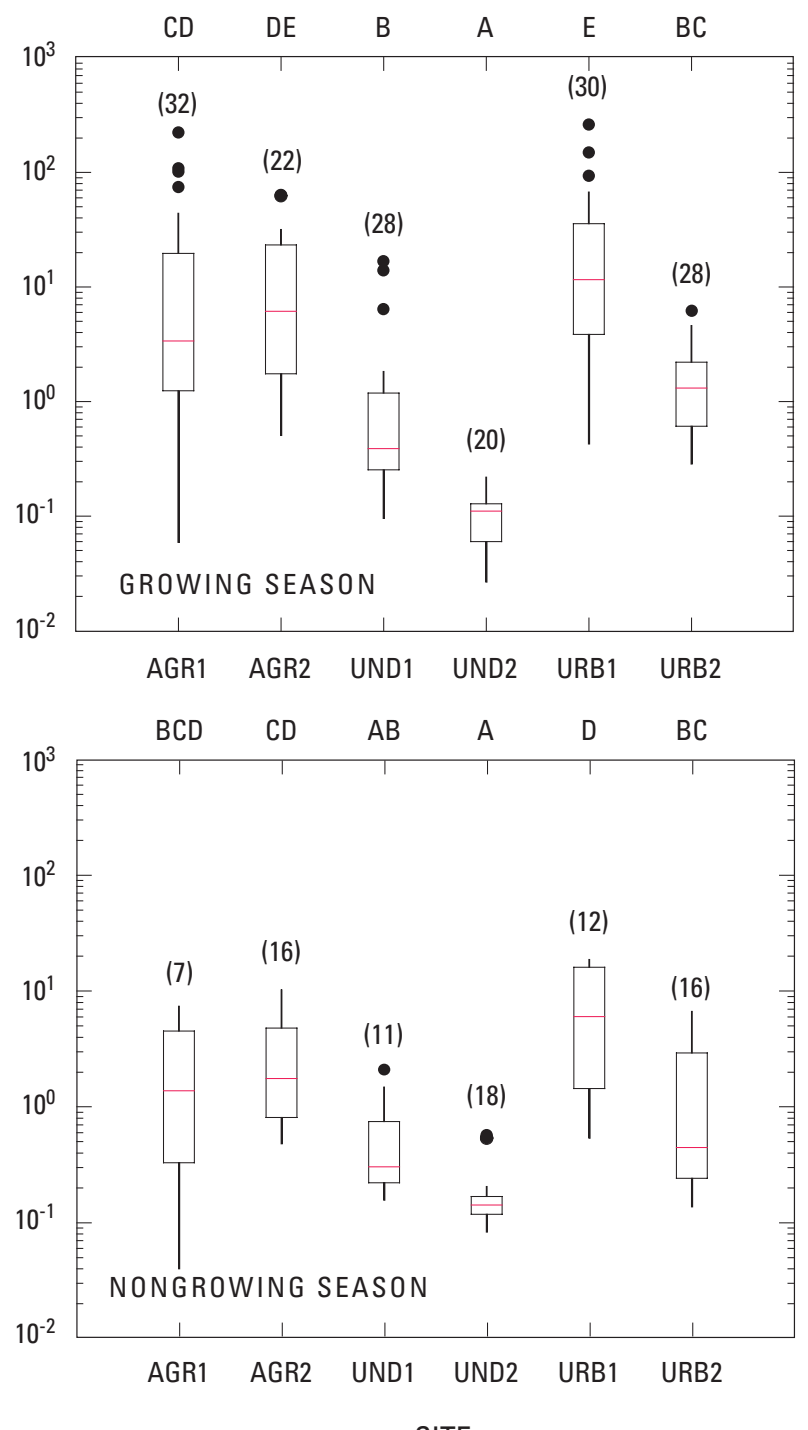

\section{EXPLANATION}

(13) Number of observations

- Outlier data value more than 1.5 times the interquartile range outside the quartile

90th percentile

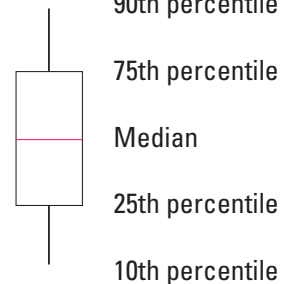

A,B-Differing letters indicate significant differences in mean values, according to the Tukey multiple-comparison test

MONITORING SITES

Agricultural

AGR1, Blacks Creek near Chesterfield, New Jersey AGR2, Alloway Creek near Watson Corner, New Jersey Undeveloped

UND1, Lahaway Creek Tributary near Prospertown, New Jersey UND2, Gravelly Run at Laurel Lake, New Jersey

Urban

URB1, Cooper River at Route 561 at Haddonfield, New Jersey URB2, South Branch Big Timber Creek Tributary at Grenloch, New Jersey

Figure 20. Distributions of area-normalized loads (yields) of total phosphorus in unfiltered water samples collected during base flow and stormflow in the growing and nongrowing seasons at monitoring sites in the lower Delaware River Basin, New Jersey, 2002-07. 
BASE FLOW

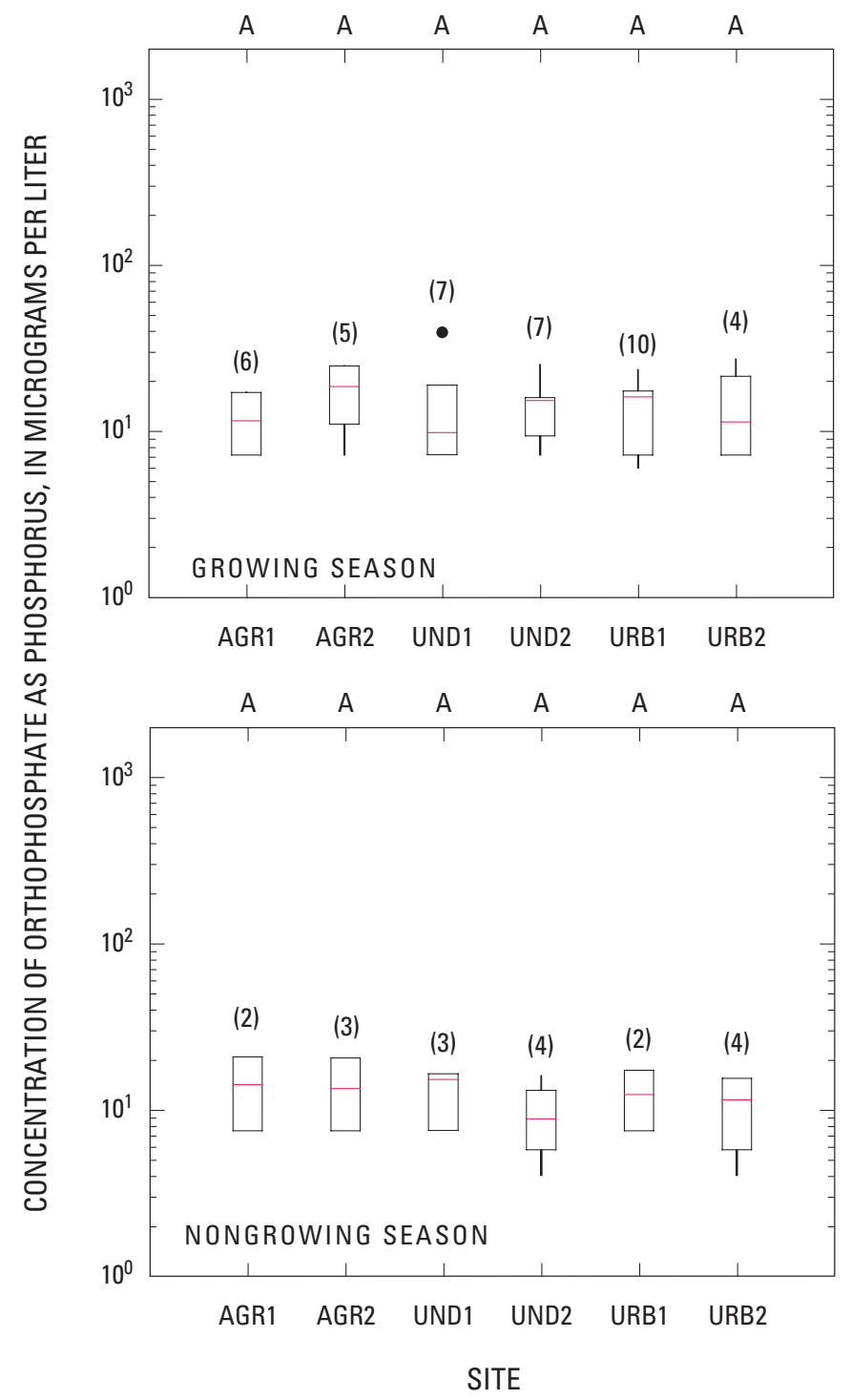

STORMFLOW
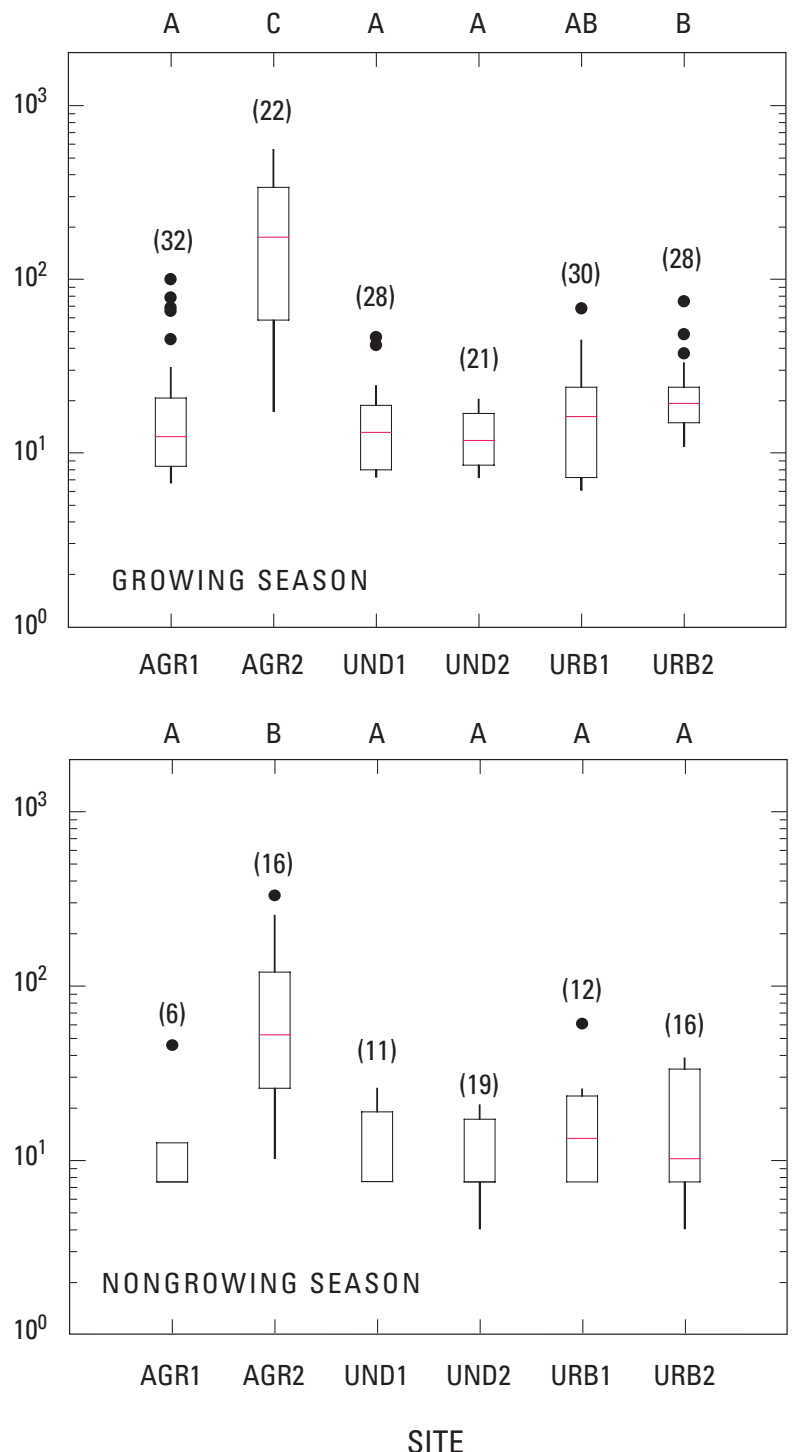

\section{EXPLANATION}

(13) Number of observations

- Outlier data value more than

1.5 times the interquartile range outside the quartile

90th percentile

75th percentile

Median

25th percentile

10th percentile
A,B-Differing letters indicate significant differences in mean values, according to the Tukey multiple-comparison test

MONITORING SITES

Agricultural

AGR1, Blacks Creek near Chesterfield, New Jersey AGR2, Alloway Creek near Watson Corner, New Jersey Undeveloped

UND1, Lahaway Creek Tributary near Prospertown, New Jersey UND2, Gravelly Run at Laurel Lake, New Jersey

Urban

URB1, Cooper River at Route 561 at Haddonfield, New Jersey URB2, South Branch Big Timber Creek Tributary at Grenloch, New Jersey

Figure 21. Distributions of orthophosphate concentrations in unfiltered water samples collected during base flow and stormflow in the growing and nongrowing seasons at monitoring sites in the lower Delaware River Basin, New Jersey, 2002-07. 
BASE FLOW

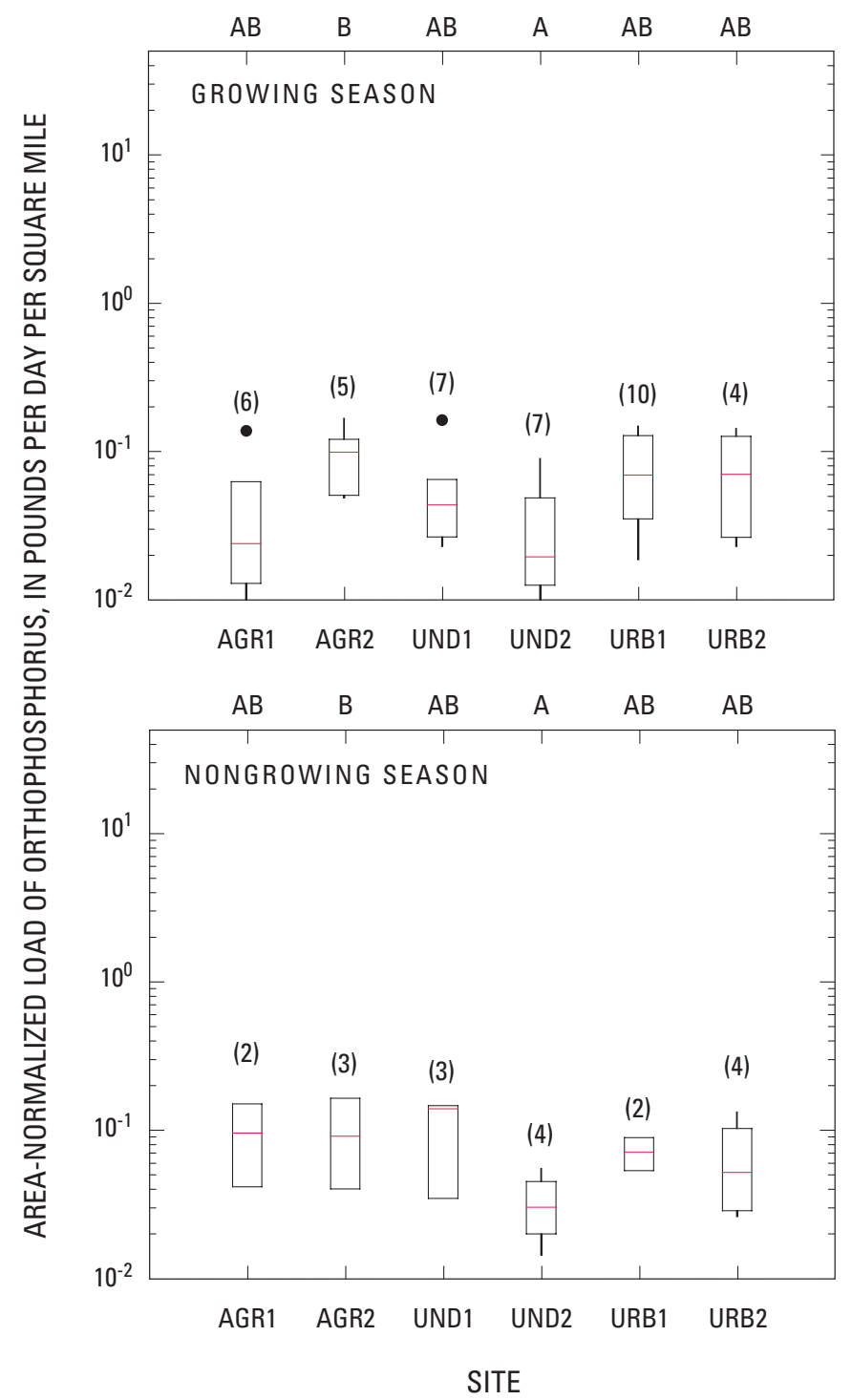

STORMFLOW
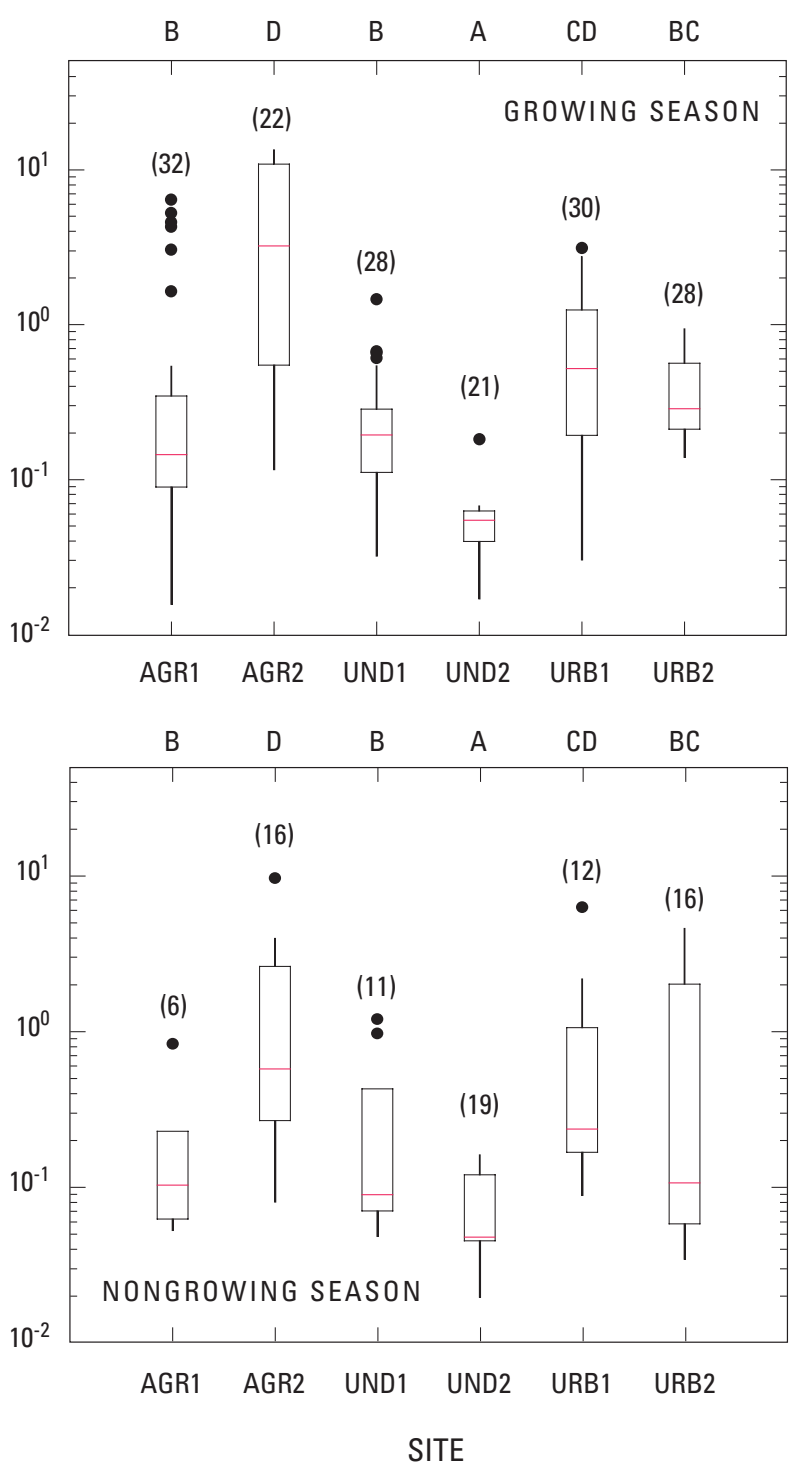

\section{EXPLANATION}

(13) Number of observations

- Outlier data value more than 1.5 times the interquartile range outside the quartile

90th percentile

75th percentile

Median

25th percentile

10th percentile
A,B-Differing letters indicate significant differences in mean values, according to the Tukey multiple-comparison test

MONITORING SITES

Agricultural

AGR1, Blacks Creek near Chesterfield, New Jersey AGR2, Alloway Creek near Watson Corner, New Jersey Undeveloped

UND1, Lahaway Creek Tributary near Prospertown, New Jersey UND2, Gravelly Run at Laurel Lake, New Jersey

Urban

URB1, Cooper River at Route 561 at Haddonfield, New Jersey URB2, South Branch Big Timber Creek Tributary at Grenloch, New Jersey

Figure 22. Distributions of area-normalized loads (yields) of orthophosphate in unfiltered water samples collected during base flow and stormflow in the growing and nongrowing seasons at monitoring sites in the lower Delaware River Basin, New Jersey, 2002-07. 
ratio is greater than 20 . Nitrogen is limited when the ratio is greater than 10, and for ratios between 20 and 10 either nutrient could be limiting (Ji, 2008). Light may be the limiting factor when both nitrogen and phosphorus are present in excess. The ratios of mean concentrations of nitrogen and phosphorus for the six sites during streamflow and base flow are listed in table 9, which also indicates which nutrient is likely to be limiting. The undeveloped stream Gravelly Run (UND2) is slightly nitrogen limiting during base flow but is neither nitrogen nor phosphorus limited during stormflow. Because of very low concentrations of both nutrients, Gravelly Run is not likely to undergo eutrophication under any conditions. The other undeveloped stream, Lahaway Creek (UND1), is slightly phosphorus limited but only under base-flow conditions. Because Lahaway Creek has relatively high concentrations of nitrogen for a stream in an undeveloped basin, additional phosphorus inputs may lead to eutrophic conditions. Both agricultural streams are highly phosphorus limited under base-flow conditions. Blacks Creek (AGR1) is neutral with respect to nutrient limitation under stormflow conditions, but Alloway Creek (AGR2) is nitrogen limited as a result of large phosphorus loads from livestock. Cooper River (URB1) is always nitrogen limited as a result of the large amounts of phosphorus (orthophosphate and total) in the stream under all flow conditions.

Eutrophication in estuarine water can be limited by the abundance of either phosphorus or nitrogen. Literature discussing this was summarized by Howarth and Marino (2006).

Table 9. Ratios of nitrogen to phosphorus in six tributaries to the Delaware River, New Jersey, 2003-07.

[N:P Ratio, ratio of the mean mass-concentration of total nitrogen as nitrogen to total phosphorus as phosphorus in water samples collected from the indicated stream in New Jersey during 2003-07; Limiting nutrient, the nutrient (total nitrogen or total phosphorus) which would be expected to change the rate of algal growth in a water body if its concentration was changed]

\begin{tabular}{ccl}
\hline Stream & N:P ratio & Limiting nutrient \\
\hline BGR1 & 117 & Phosphorus \\
AGR2 & 67.9 & Phosphorus \\
UND1 & 22.5 & Phosphorus \\
UND2 & 7.02 & Nitrogen \\
URB1 & 5.42 & Nitrogen \\
URB2 & 39.2 & Phosphorus \\
& Stormflow conditions & \\
\hline AGR1 & 15.5 & Either \\
AGR2 & 6.73 & Nitrogen \\
UND1 & 18 & Either \\
UND2 & 12.6 & Either \\
URB1 & 1.91 & Nitrogen \\
URB2 & 14.1 & Either \\
\hline
\end{tabular}

Initially, phosphorus was thought to be more often limited, with carbon limitation also possible (Bartsch, 1972). However, as studies on the nature and causes of eutrophication were completed, it became increasingly clear that nitrogen is most often limited in estuaries. This finding has implications for streams in the lower Delaware River Basin, especially Alloway Creek and the Cooper River, which deliver substantial loads of nitrogen to the Delaware Bay.

\section{Bacteria}

Densities of fecal coliform bacteria, specifically enterococci strains and Escherichia coli (E. coli) bacteria, can be used as an indicator of contamination from fecal material. Many of the organisms can be harmful to human health. Fecal coliform bacteria reside in the intestinal tracts of mammals and birds where they symbiotically assist in the digestion process. Specifically, E. coli bacteria are most often found in the intestinal tracts of healthy cattle and other mammals.

Quantitative fecal coliform data are reported as the most probable number (MPN) of coliform bacteria in 100 milliliters $(\mathrm{mL}$ ) of water (American Public Health Association and others, 1999). The numerical criteria for FW2 streams, the classification of all stream reaches in this study, are "fecal coliform levels shall not exceed a geometric average of $200 \mathrm{MPN} / 100 \mathrm{~mL}$ nor should more than 10 percent of the samples collected during any 30-day period exceed 400 MPN/100 mL" (New Jersey Department of Environmental Protection, 1998). The MPN is obtained by serially diluting a sample, usually in order-of-magnitude steps with several replicates at each dilution level, then counting the number of replicates at each level that contain a viable population of the organism of interest. A "positive" replicate is indicated by color change, gas evolution, cloudiness of the sample, or some other chemical or physical change that indicates the presence of a viable microbial population. The assumption is made that a detectable population can arise from a single viable individual. The numbers of positive replicates at the lowest three dilutions are used with a probability function to determine the MPN of viable organisms in the original sample. The MPN is itself an approximation and carries its own sources of error, which increase as the number of culture tubes decreases. The upper and lower bounds of the 95 -percent confidence interval can differ by as much as a factor of 10 (American Public Health Association and others, 1999). Large differences in MPN among samples, therefore, must be present before heterogeneity among samples can be demonstrated to be significant with respect to viable microbial agents, such as fecal coliform bacteria.

Alloway Creek (AGR2) generally had the highest concentrations and loads of fecal coliform bacteria among the six streams (fig. 23). This occurred during base flow and stormflow, and during growing and nongrowing seasons, probably the result of cattle in and around the stream. The other agricultural stream (Blacks Creek, AGR1) had relatively low concentrations of fecal coliform bacteria, compared 
BASE FLOW

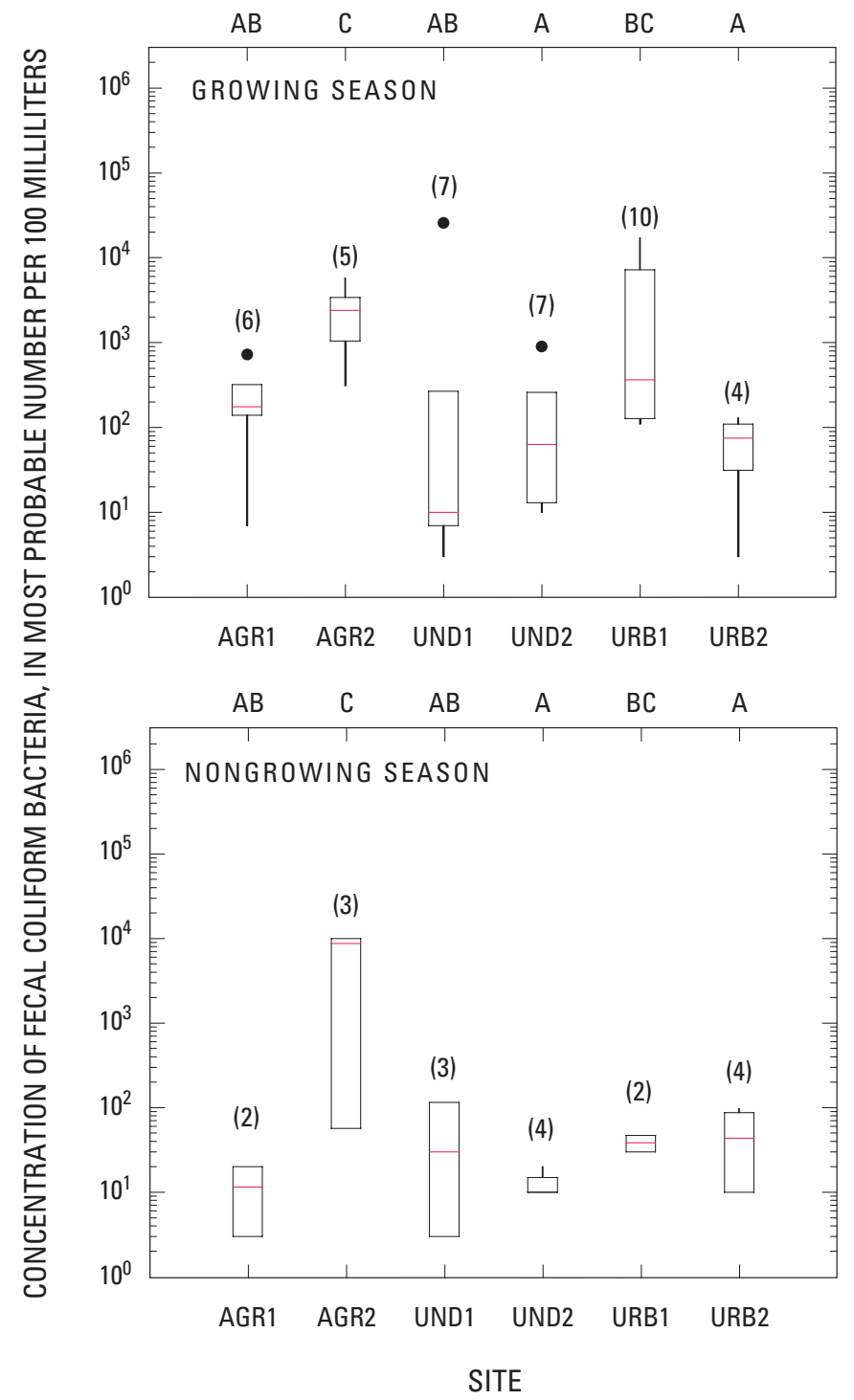

STORMFLOW
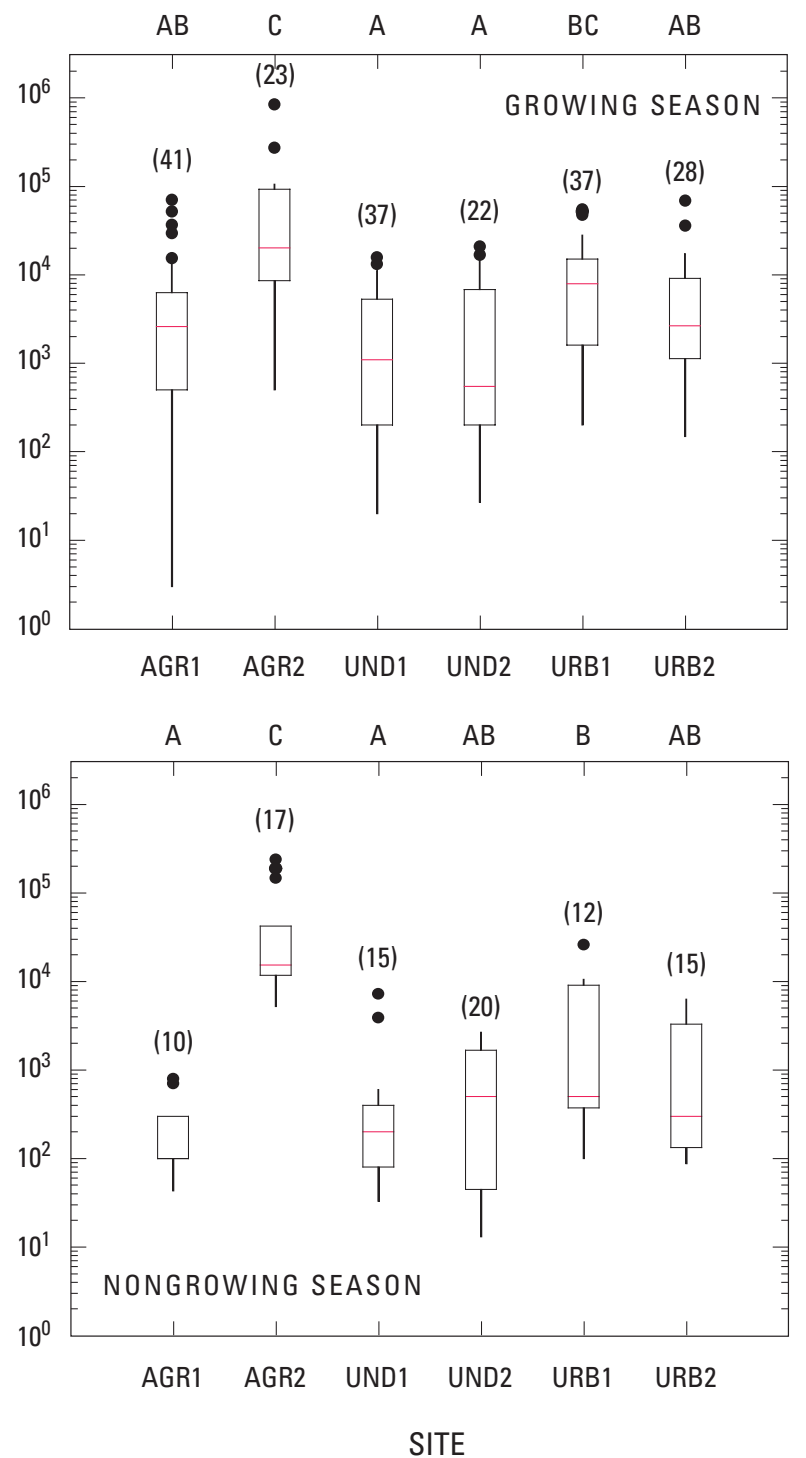

\section{EXPLANATION}

(13) Number of observations

- Outlier data value more than 1.5 times the interquartile range outside the quartile

90th percentile

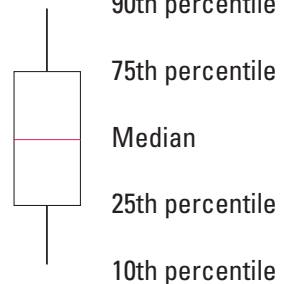

$\mathrm{A}, \mathrm{B}$-Differing letters indicate significant differences in mean values, according to the Tukey multiple-comparison test

MONITORING SITES

Agricultural

AGR1, Blacks Creek near Chesterfield, New Jersey AGR2, Alloway Creek near Watson Corner, New Jersey Undeveloped

UND1, Lahaway Creek Tributary near Prospertown, New Jersey UND2, Gravelly Run at Laurel Lake, New Jersey

Urban

URB1, Cooper River at Route 561 at Haddonfield, New Jersey URB2, South Branch Big Timber Creek Tributary at Grenloch, New Jersey

Figure 23. Distributions of fecal coliform bacteria concentrations in unfiltered water samples collected during base flow and stormflow in the growing and nongrowing seasons at monitoring sites in the lower Delaware River Basin, New Jersey, 2002-07. 
to those in the Cooper River (URB1). Without livestock or urban sources, it is reasonable that only natural sources, such as wild birds and mammals, would contribute fecal coliform bacteria to the stream. High concentrations and loads of fecal coliform bacteria also were observed in samples from the Cooper River (URB1) and Big Timber Creek (URB2), the two urban streams. TMDLs have been established for both of these streams (New Jersey Department of Environmental Protection, 2004). The resulting waste allocations for these streams require a reduction of fecal coliform bacteria of 97 percent for Cooper River and 85 percent for Big Timber Creek, on the basis of a 400 -colony forming units per 100 milliliters $(\mathrm{CFU} / 100 \mathrm{~mL}$ ) criteria. Sources of fecal coliforms were stated in the TMDL document as Canada geese and domestic pets. Strategies for reducing loads are given in Stormwater Phase II final rule (U.S. Environmental Protection Agency, 2000).

Loads of fecal coliform bacteria (fig. 24) were highest for Alloway Creek (AGR2), lowest for both undeveloped streams, and higher for Cooper River (URB1) than for the other urban stream (Big Timber Creek, URB2), following a pattern similar to that of the fecal coliform bacteria concentrations. Because most of the domestic wastewater-treatment plants have been removed from these streams, future management strategies will need to be based on controlling other coliform inputs, such as from livestock, domestic pets, and wildlife.

\section{Total Suspended Solids}

The term "total solids" refers to matter suspended or dissolved in water or wastewater and is related to both specific conductance and turbidity. Total solids (also referred to as total residue) is the term used for material left in a container after evaporation and drying of a water sample. Total solids includes both total suspended solids (TSS), the part of total solids retained in a filter with a specified pore size, and total dissolved solids, the part that passes through the filter (American Public Health Association and others, 1999). In most surface water, dissolved solids are a minor percentage of the suspended-solids mass, especially in stormflow. In base flow, however, dissolved solids and suspended solids can be approximately equal.

Method 2540D in American Public Health Association and others (1999) specifies the use of glass-fiber filter disks with a pore size of about 1.5 microns for separating suspended solids from the water sample. The water sample passes through the filter under negative pressure; then the filter is rinsed to remove dissolved solids and dried at 103 to 105 degrees Celsius for at least 1 hour. The increase in filter mass (milligrams) divided by the sample volume (liter) is the TSS in milligrams per liter. TSS can include a wide variety of material, such as silt, decaying plant and animal matter, industrial wastes, and sewage. High concentrations of suspended solids can cause problems for stream health and aquatic life. For example, light penetration of water is reduced as TSS increases, which can reduce photosynthesis by algae and other aquatic plants, in turn reducing the production of oxygen in the water. Decreased water clarity from suspended solids also interferes with the ability of fish to catch prey and can clog the gills of fish, which leads to poor health or even death. Trace elements and organic compounds are often adsorbed onto suspended particles, which may be ingested by aquatic organisms, leading to toxicity. The USEPA does not provide a standard for TSS in drinking water but does specify that turbidity (largely resulting from suspended solids) may not exceed 5 nephelometric units (NTU) or 1 NTU for drinking-water systems using filtration. The New Jersey criterion for TSS is $40 \mathrm{mg} / \mathrm{L}$ for FW2-NT streams (New Jersey Department of Environmental Protection, 1998).

As expected, TSS concentrations and yields (figs. 25 and 26) were low in samples collected during base flow from all six sites when compared with that in samples collected during stormflow. During stormflow, concentrations and loads increased but were highly variable for each stream, and relations between land use and TSS were not clearly evident. Gravelly Run (UND2) generally had the lowest loads suspended solids among the six streams. Loads for Cooper River (URB1) were significantly higher than those for Big Timber (URB2), the other urban stream, and statistically equivalent to the loads for two agricultural streams. Loads tended to be higher during the growing season than the nongrowing season. Concentrations and loads of suspended solids are important, as they affect the concentrations and loads of nutrient species as a result of adsorption and desorption.

\section{Estimated Annual Yields of Total Nitrogen and Total Phosphorus}

Annual loads of nitrogen and phosphorus species are listed in table 10 and are shown in figure 27. Gravelly Run had small loads of phosphorus when compared to loads for all other streams. Nearly all the phosphorus and nitrogen loads occurred during base flow. This is somewhat counterintuitive, given that phosphorus species are generally less mobile in groundwater than are nitrogen species. The low phosphorus loads can be explained by the lack of point- and nonpointsource inputs in this basin. The greater phosphorus loads from discharging groundwater could be related to naturally occurring phosphorus in geologic formations or from previous land-use activities. The Bridgeton Formation, which underlies Gravelly Run, contains phosphate nodules and may be a source. Base flow also is the principal source of nitrogen to Gravelly Run. This is reasonable, given the lack of surfacewater inputs and the possibility there are groundwater sources from outside this relatively pristine basin. The drainage basin of the other undeveloped site, Lahaway Creek, does contain some urban land use (13.6 percent) and agricultural land use (4.6 percent). The load of total phosphorus is about 3 times higher than that in the Gravelly Run Basin (fig. 20), and the load is relatively equally divided between base flow and runoff during the nongrowing season; however, during the growing season, total phosphorus load is substantially lower during 

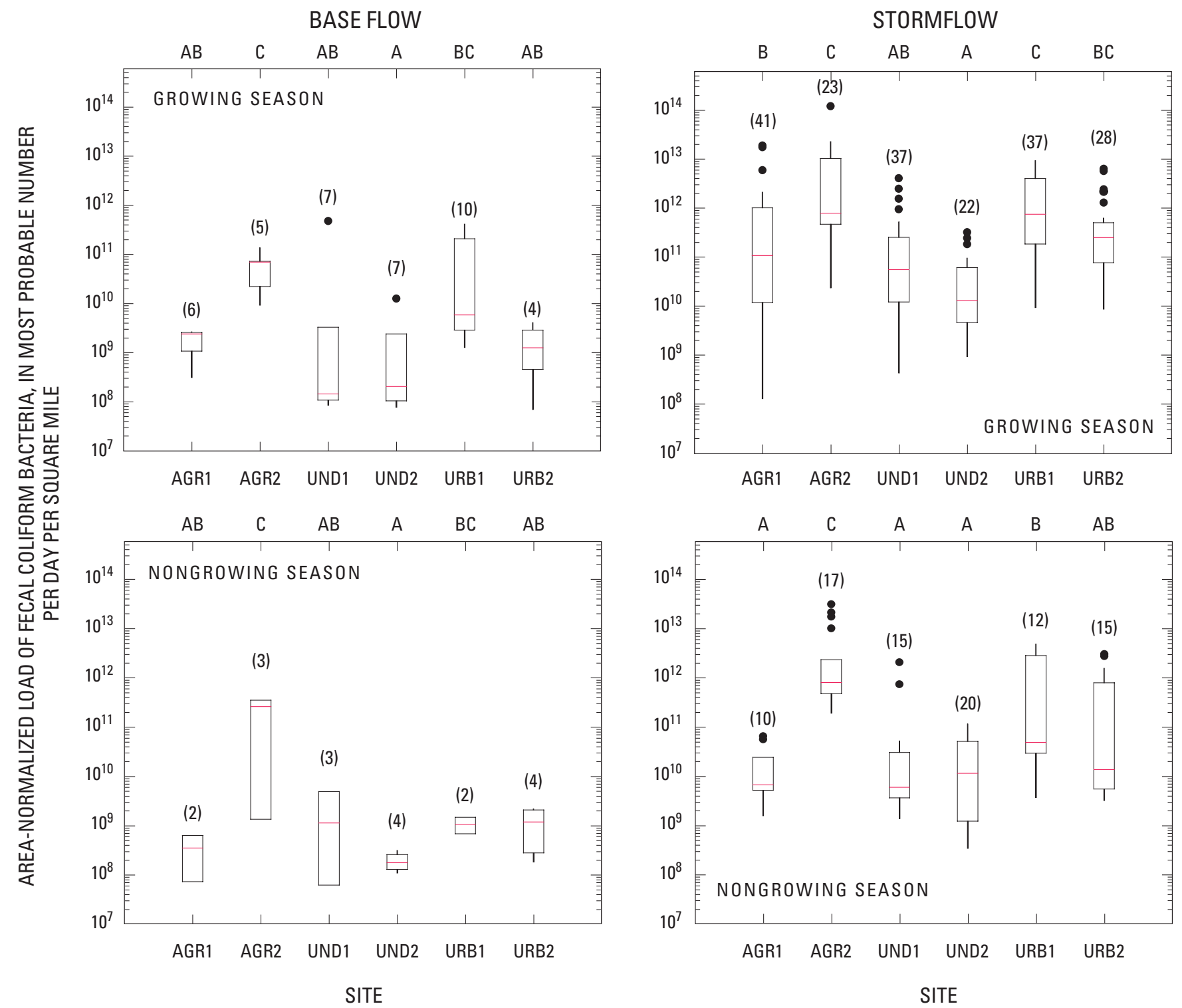

\section{EXPLANATION}

(13) Number of observations

- Outlier data value more than

1.5 times the interquartile range outside the quartile

90th percentile

75th percentile

Median

25th percentile

10th percentile
A,B-Differing letters indicate significant differences in mean values, according to the Tukey multiple-comparison test

MONITORING SITES

Agricultural Undeveloped

AGR1, Blacks Creek near Chesterfield, New Jersey

AGR2, Alloway Creek near Watson Corner, New Jersey

UND1, Lahaway Creek Tributary near Prospertown, New Jersey UND2, Gravelly Run at Laurel Lake, New Jersey

Urban

URB1, Cooper River at Route 561 at Haddonfield, New Jersey URB2, South Branch Big Timber Creek Tributary at Grenloch, New Jersey

Figure 24. Distributions of area-normalized loads (yields) of fecal coliform bacteria in unfiltered water samples collected during base flow and stormflow in the growing and nongrowing seasons at monitoring sites in the lower Delaware River Basin, New Jersey, 2002-07. 
BASE FLOW

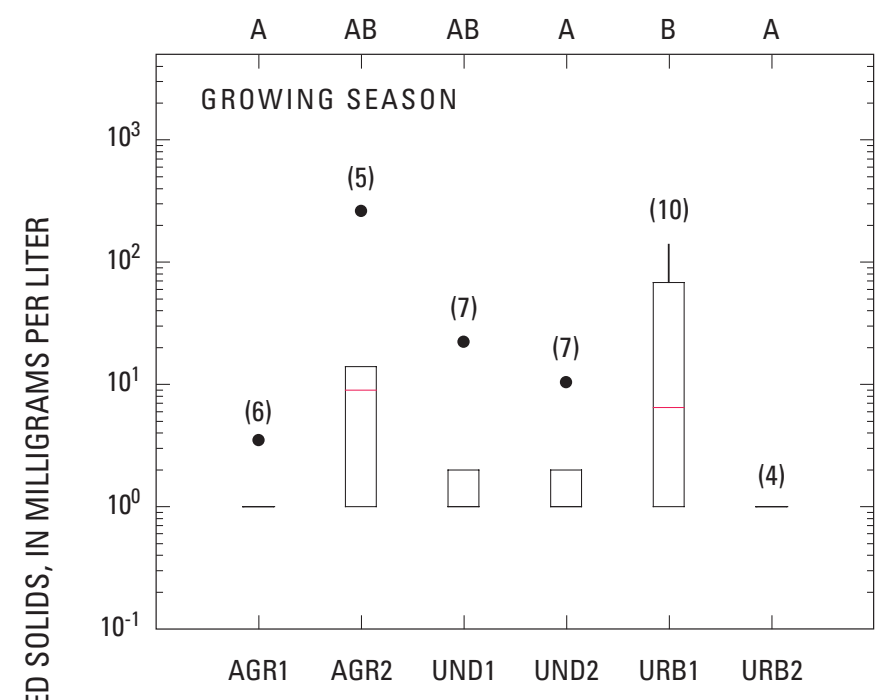

눙

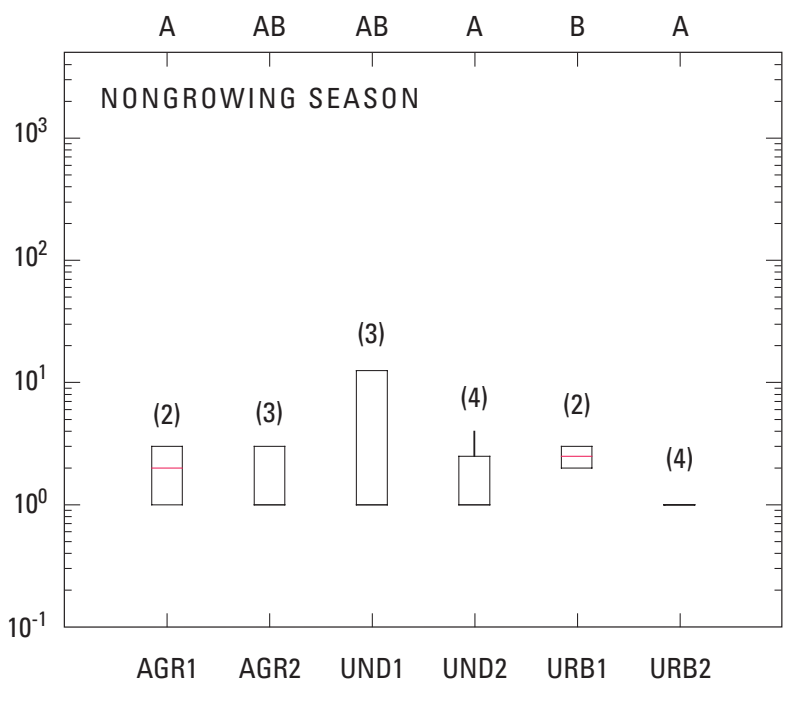

SITE
STORMFLOW
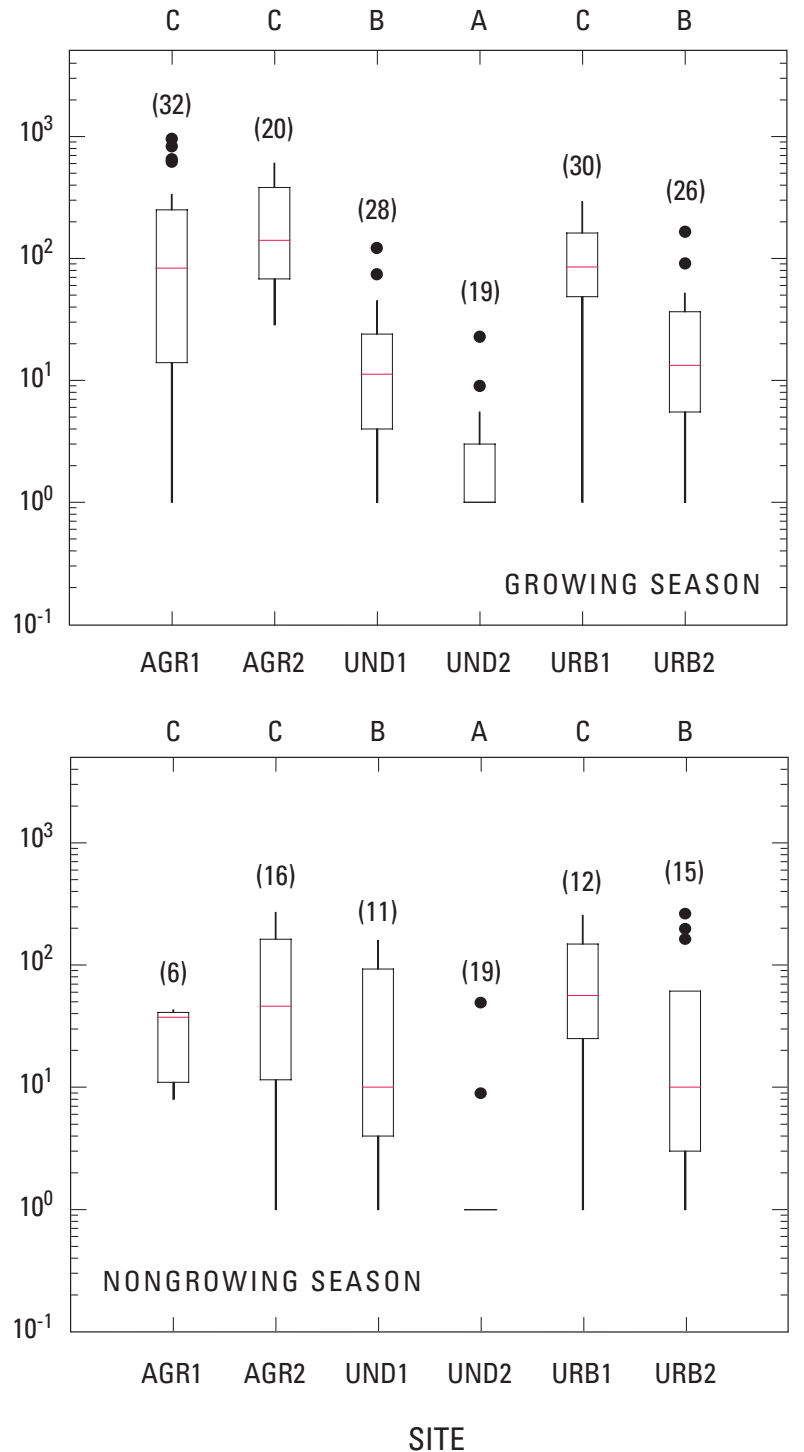

\section{EXPLANATION}

(13) Number of observations

- Outlier data value more than

1.5 times the interquartile range outside the quartile

90th percentile

75th percentile

Median

25th percentile

10th percentile
A,B-Differing letters indicate significant differences in mean values, according to the Tukey multiple-comparison test

MONITORING SITES

Agricultural

AGR1, Blacks Creek near Chesterfield, New Jersey AGR2, Alloway Creek near Watson Corner, New Jersey Undeveloped

UND1, Lahaway Creek Tributary near Prospertown, New Jersey UND2, Gravelly Run at Laurel Lake, New Jersey

Urban

URB1, Cooper River at Route 561 at Haddonfield, New Jersey URB2, South Branch Big Timber Creek Tributary at Grenloch, New Jersey

Figure 25. Distributions of total suspended solids concentrations in unfiltered water samples collected during base flow and stormflow in the growing and nongrowing seasons at monitoring sites in the lower Delaware River Basin, New Jersey, 2002-07. 
BASE FLOW

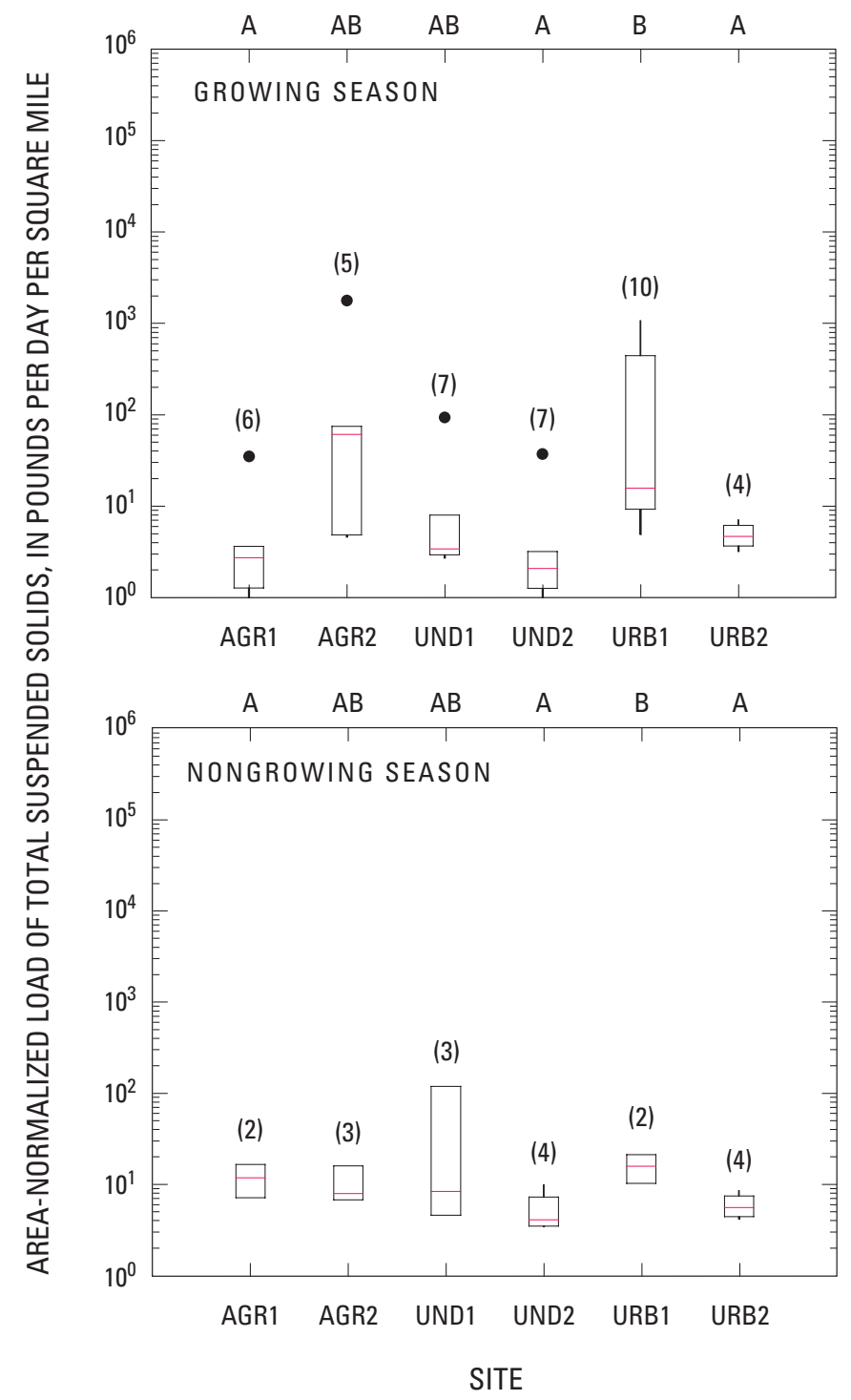

STORMFLOW
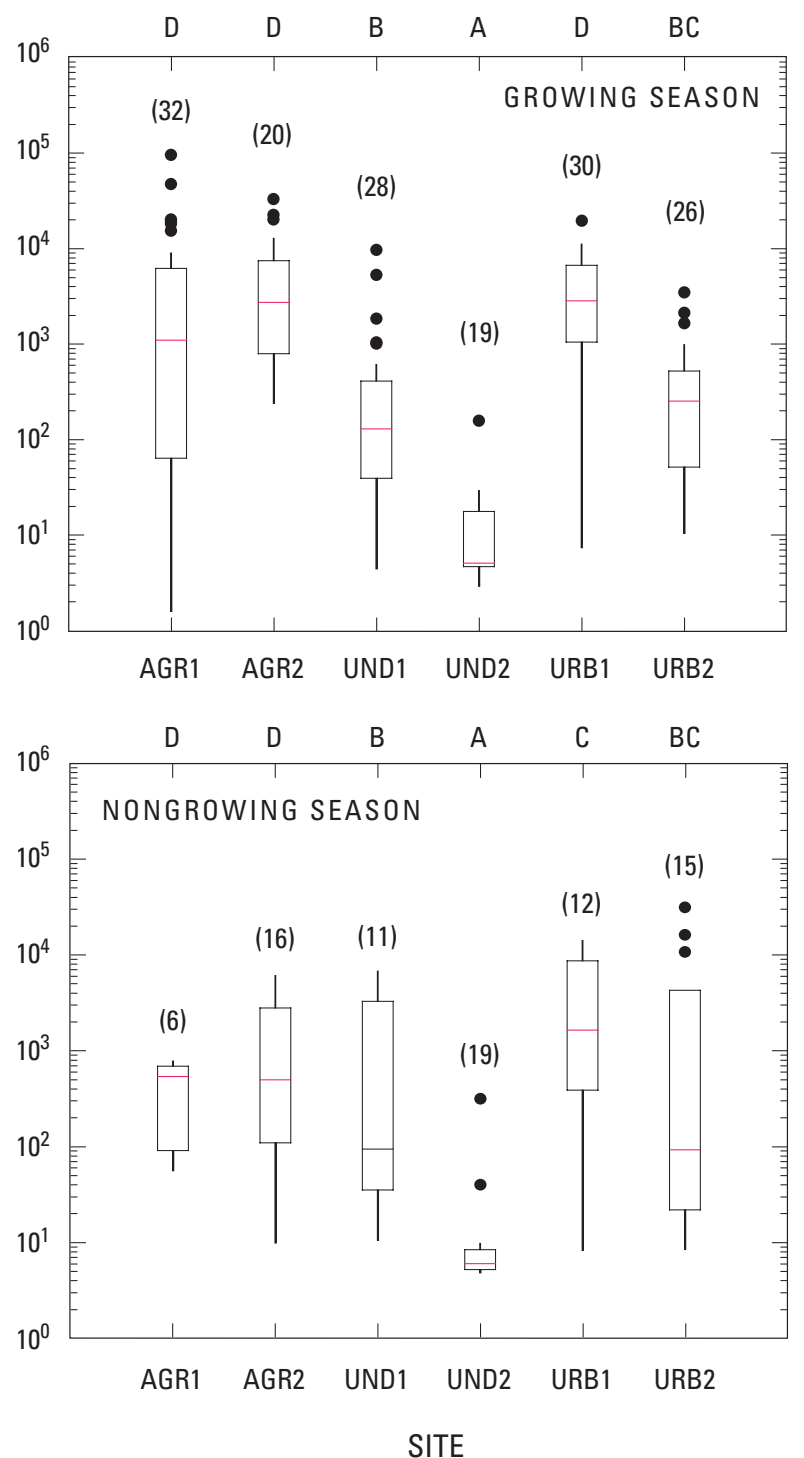

\section{EXPLANATION}

(13) Number of observations

- Outlier data value more than 1.5 times the interquartile range outside the quartile

90th percentile

75th percentile

Median

25th percentile

10th percentile
A,B-Differing letters indicate significant differences in mean values, according to the Tukey multiple-comparison test

MONITORING SITES

Agricultural

AGR1, Blacks Creek near Chesterfield, New Jersey AGR2, Alloway Creek near Watson Corner, New Jersey Undeveloped

UND1, Lahaway Creek Tributary near Prospertown, New Jersey UND2, Gravelly Run at Laurel Lake, New Jersey

Urban

URB1, Cooper River at Route 561 at Haddonfield, New Jersey URB2, South Branch Big Timber Creek Tributary at Grenloch, New Jersey

Figure 26. Distributions of area-normalized loads (yields) of total suspended solids in unfiltered water samples collected during base flow and stormflow in the growing and nongrowing seasons at monitoring sites in the lower Delaware River Basin, New Jersey, 2002-07. 
Table 10. Annual loads of selected water-quality characteristics for three streams in the lower Delaware River Basin, New Jersey.

[Total $\mathrm{N}$, total nitrogen; Organic $\mathrm{N}$, organic nitrogen; $\mathrm{NO}_{3}+\mathrm{NO}_{2}$, nitrate plus nitrite; Total $\mathrm{P}$, total phosphorus]

\begin{tabular}{|c|c|c|c|c|c|c|c|}
\hline \multirow{2}{*}{$\begin{array}{c}\text { Station } \\
\text { abbreviation }\end{array}$} & \multirow{2}{*}{$\begin{array}{l}\text { Station name } \\
\text { (Identifier) }\end{array}$} & \multicolumn{6}{|c|}{ Annual loads of water-quality characteristic, in pounds per year per square mile } \\
\hline & & Total N & Organic $\mathbf{N}$ & Ammonia & $\mathrm{NO}_{3}+\mathrm{NO}_{2}$ & Total P & Orthophosphate \\
\hline UND2 & Gravelly Run & 173 & 77 & 26 & 87 & 28 & 10 \\
\hline URB1 & Cooper River & 10,688 & 5,668 & 1,684 & 3,438 & 6,043 & 303 \\
\hline AG1 & Blacks Creek & 4,176 & 464 & 51 & 3,758 & 186 & 33 \\
\hline AG2 & Alloway Creek & 14,730 & 4,292 & 1,120 & 9,634 & 3,250 & 70 \\
\hline
\end{tabular}

base flow than during stormflow (fig. 20). Total nitrogen load is about 10 times higher than that in Gravelly Run, again divided nearly equally between base flow and runoff. In this basin the effects of small amounts of agricultural and urban land use are evident in the elevated loads of nitrogen and phosphorus in the runoff.

Values for nitrogen and phosphorus loads for Big Timber Creek Basin were surprisingly close to those of Lahaway Creek Basin. The large amount of urban land use (73.7 percent) does not appear to contribute a greater nutrient load to the stream than the small amount of agricultural land use in the Lahaway Creek Basin. The small amount of agricultural land in the Blacks Creek Basin is present mostly upstream from the headwaters; runoff from these areas may not reach the sampling site. Though land-use percentages are similar for the Cooper River and Blacks Creek Basins, nutrient loads were substantially greater for the Cooper River Basin (by a factor of about 15). This may be partially due to historical wastedisposal practices; the Cooper River was highly eutrophic with many domestic wastewater-treatment facilities along its length until the 1970s and 1980s, when they were removed. Also, the Cooper River runs through many lakes and impoundments created by building artificial dams. Many of these are a century or more old and have been accumulating silt for decades. A portion of the silt is released during each storm, and nutrients may be resuspended. Much of the nitrogen in Cooper River runoff is in the form of organic nitrogen, which can be bound to sediment. The abundant ammonia can be released from the anoxic bottom sediment, whereas nitrate can be aerobically generated from ammonia by in-stream processes. Phosphorus loads also were substantially higher in the Cooper River than in Blacks Creek and the two agricultural basins, and this is consistent with the sediment-resuspension concept. Two major golf country clubs are present along the Cooper River, which may be an additional source of nutrients from turf fertilization.

The drainage basins of Blacks Creek and Alloway Creek are largely agricultural. Neither have substantial percentages of urban land use; however, Blacks Creek Basin has a higher percentage of undeveloped land and a lower percentage of agricultural land than Alloway Creek Basin. Cattle were observed during several visits to Alloway Creek, and cattle were often seen in the creek. Evidence of cattle waste products was abundant. No cattle were observed in the Blacks Creek Basin, and the agriculture appeared to consist of row crops. Nearly all of the nitrogen in Blacks Creek is in the form of nitrate plus nitrite, whereas a substantial portion of the nitrogen present in Alloway Creek is in the form of organic nitrogen and ammonia. This is consistent with the different agricultural focuses in the two basins.

Load values show a strong relation with land use. With the exception of the Cooper River site, elevated nutrient levels can be directly related to recent land-use patterns. As mentioned above, there is strong evidence that the nutrient load in the Cooper River is in large part contributed by sedimentstored nutrients that are released during storms. 


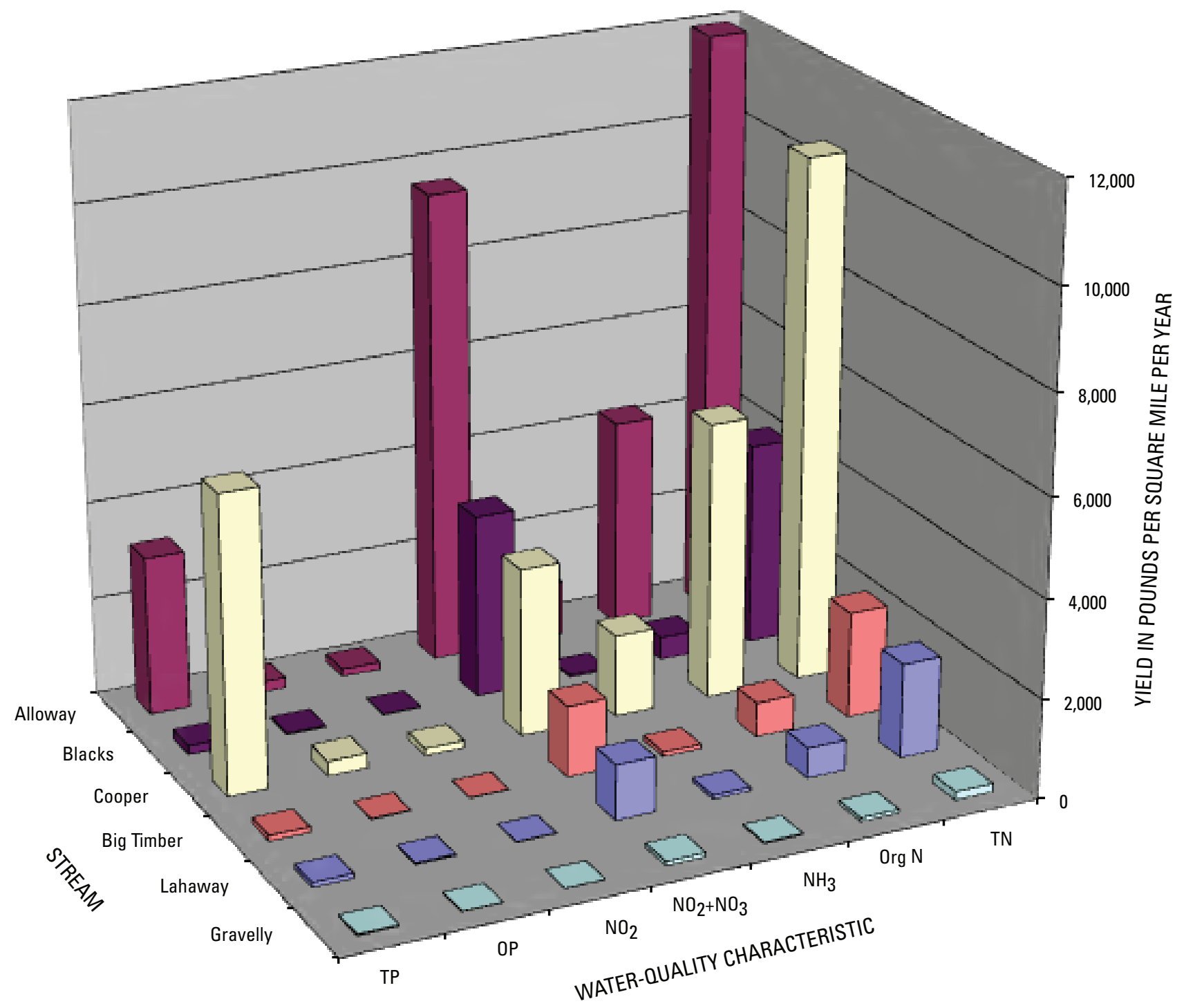

EXPLANATION

Streams: Alloway, Alloway Creek near Watson's Corner, NJ; Blacks, Blacks Creek near Chesterfield, NJ; Cooper, Cooper River at Route 561 at Haddonfield, NJ; Big Timber, South Branch Big Timber Creek at Grenloch, NJ; Lahaway, Lahaway Creek near Prospertown, NJ; Gravelly, Gravelly Run near Laurel Lake, NJ

Nutrient Species: TP, total phosphorus; $\mathrm{OP}$, orthophosphate; $\mathrm{NO}_{2}$, nitrite; $\mathrm{NO}_{2}+\mathrm{NO}_{3}$, nitrite plus nitrate; $\mathrm{NH}_{3}$, ammonia; Org $\mathrm{N}$, organic nitrogen as $\mathrm{N}$; $\mathrm{TN}$, total nitrogen

Figure 27. Yields of phosphorus and nitrogen nutrient species in six streams in the lower Delaware River Basin, New Jersey, 2002. 


\section{Summary and Conclusions}

Water quality and streamflow were monitored during eight storms and during base flow eight times each at six streams in the lower Delaware River Basin, New Jersey, during 2003-07. Two streams were chosen for each of three predominant land uses - agricultural, urban, and undeveloped. Blacks Creek (AGR1) and Alloway Creek (AGR2) are predominantly agricultural, Lahaway Creek (UND1) and Gravelly Run (UND2) are mostly undeveloped, and Cooper River (URB1) and South Branch Big Timber Creek (URB2) are mostly urban. Sampling events were scheduled during growing and nongrowing seasons to observe seasonal effects. Water samples for nutrient analysis were collected several times during each storm so that total load and variability of load during storms could be determined. Samples were analyzed to determine concentrations of several nitrogen and phosphorus species. The yield (area-normalized load) was calculated for each nutrient species for each sample collected. Two-way ANOVA of ranked data was used to simultaneously test for differences in nutrient-species concentrations and yields among sites, and between growing and nongrowing seasons. This was followed with the Tukey multiple comparison test.

Nitrate plus nitrite was the most abundant nitrogen constituent at all sites, exceeding 50 percent of the nitrogen mass in most samples. Organic nitrogen also was substantial (mean value, 32 percent of total nitrogen). When detected, nitrite was present at low levels and represented about 1 percent of the total nitrogen mass. Ammonia typically represented 3 to 5 percent.

Concentrations and yields of nitrogen and phosphorus species are strongly related to land use with agricultural activities contributing the most nutrient mass to the streams, followed by urban land use. Forests and wetlands contributed the least amount of nutrient mass per unit land area. UND2, which had essentially no urban development or agriculture, had significantly lower nutrient concentrations and yields than any other basin. AGR2 had the highest concentrations and yields of total nitrogen. Most of this was in the form of nitrate plus nitrite; however, a substantial amount of organic nitrogen and ammonia were contributed. The AGR2 basin also contributed a large amount of phosphorus. Total nitrogen concentration and yield values for AGR1 were about one-third of those for AGR2, and nearly all of the nitrogen was in the form of nitrate plus nitrite. Phosphorus loads were much lower for AGR1 than for AGR2. The difference in load values between these basins is consistent with the difference in the nature of the agriculture: livestock were present only in the Alloway Creek Basin (AGR2). Annual nitrogen and phosphorus loads at URB1, which is largely urban, were high and more similar to the agricultural basins than to the other urban basin (URB2). A long history of numerous domestic wastewater-treatment plants operating along the length of Cooper River, and the presence of sediment-laden impoundments, are reasonable explanations for this observation. The large organic nitrogen and total phosphorus loads are consistent with nutrient release from sediment in the Cooper River streambed during storms.

For seasonality, there was no significant difference in concentration of any nutrient species between growing and nongrowing seasons during base flow. Fecal coliform concentrations were significantly higher in the growing season, probably as a result of warmer temperatures. Yields of all nitrogen species during base flow differed significantly between seasons, probably due to hydrologic variability. Concentrations and yields of most nutrient species during stormflow were significantly different between growing and nongrowing seasons, although box plots revealed that the differences were related more to variability than to median values.

\section{References Cited}

American Public Health Association, American Water Works Association, and Water Environment Federation, 1999, Standard methods for the examination of water and wastewater (29th ed.): Washington, D.C., American Public Health Association, variously paged.

Anderson, J.R., Hardy, E.E., Roach, J.T., and Witmer, R.E., 1976. A land use and land cover classification system for use with remote sensor data: A revision of the land use classification system as presented in U.S. Geological Survey Circular 671: U.S. Geological Survey Professional Paper 964, $41 \mathrm{p}$.

Baker, R.J., and Hunchak-Kariouk, K., 2006, Relations of water quality to streamflow, season, and land use for four tributaries to the Toms River, Ocean County, New Jersey, 1994-99: U.S. Geological Survey Scientific Investigations Report 2005-5274, 72 p.

Bartsch, A.F., 1972, Nutrients and eutrophication — prospects and options for the future, in Likens, G.E., ed., Nutrients and eutrophication: The limiting nutrient controversy: Lawrence, Kansas, The American Society of Limnology and Oceanography, $297 \mathrm{p}$.

Delaware Inland Bays Estuary Program. 1993, Characterization of the inland bays estuary: Dover, DE, Report to the Delaware Inland Bays National Estuary Program, Delaware Department of Natural Resources and Environmental Control.

Delaware River Basin Commission, 1994, Delaware River and Bay water quality assessment: 1992-1993: West Trenton, New Jersey, Delaware River Basin Commission, 305(b) report, $50 \mathrm{p}$. 
Fischer, J.M., Riva-Murray, Karen, Hickman, R.E., Chichester, D.C., Brightbill, R.A., Romanok, K.M., and Bilger, M.D., 2004, Water quality in the Delaware River Basin, Pennsylvania, New Jersey, New York, and Delaware, 1998-2001: U.S. Geological Survey Circular 1227, 38 p.

Fusillo, T.V., 1981, Impact of suburban residential development on water resources in the area of Winslow Township, Camden County, New Jersey: U.S. Geological Survey Water-Resources Investigations Report 81-27, 38 p.

Gondar, D., Thacker, S.A., Tipping, E., Baker, A., 2008, Functional variability of dissolved organic matter from the surface water of a productive lake: Water Research, v. 42, no. 1-2, p. 81-90.

Granéli, E., and Turner, J.T., eds., 2006, Ecology of harmful algae: Heidelberg, Germany, Springer, Series: Ecological Studies, v. 189, 413 p.

Gray, D.M., 1970, Handbook on the principles of hydrology: Huntington, New York, Water Information Center, Inc., p. 7.7 .

Greeley-Polhemus Group, Inc., 1990, Final report: Delaware Estuary Program land use management inventory and assessment: West Chester, PA, Greeley-Polhemus Group, Inc., 229 p.

Hasse, John E., and Lathrop, Richard, G., 2001, Measuring Urban Growth in New Jersey: New Brunswick, Grant F. Walton Center for Remote Sensing \& Spatial Analysis, Rutgers University, NJ. 43 p.

Hasse, J., and Lathrop, R.G., 2008, Tracking New Jersey's dynamic landscape: urban growth and open space loss 1986-1995-2002. Final report: Glassboro, NJ, Rowan University, and New Brunswick, NJ, Rutgers University, $67 \mathrm{p}$.

Helsel, D.R., and Hirsch, R.M., 2002, Statistical methods in water resources: U.S. Geological Survey Techniques of Water-Resources Investigations, book 4, chap. A3, 522 p.

Howarth, R.W., and Marino, R., 2006, Nitrogen as the limiting nutrient for eutrophication in coastal marine ecosystems, evolving views over three decades: Limnology and Oceanography, v. 51, no. 1, part 2, p. 364-376.

Hunchak-Kariouk, Kathryn, Buxton, D.E., Hickman, R.E.,1999, Relations of surface-water quality to streamflow in the Atlantic Coastal, Lower Delaware River, and Delaware Bay basins, New Jersey, water years 1976-93: U.S. Geological Survey Water-Resources Investigations Report 98-4244, 146 p.

Ji, Zhen-Gang, 2008, Modeling rivers, lakes and estuaries: Hoboken, NJ, Wiley Interscience, John Wiley \& Sons, Inc., 676 p.
Jordan, T.J., Weller, D.E., and Correll, D.L., 2003, Sources of nutrient inputs to the Patuxent River estuary: Estuaries, v. 26, no. 2, part A, p. 226-243.

Kennish, M.J., ed., 1997, Practical handbook of estuarine and marine pollution: Boca Raton, FL, CRC Press, The CRC Marine Science Series, 524 p.

Lathrop, R.G., 2000, New Jersey land cover change analysis project, 1972-1984-1995: New Brunswick, N.J., Center for Remote Sensing and Spatial Analysis, Cook College, 38 p.

Lehr, J.H., Keeley, J.J., Lehr, J.J., eds., 2005, Water Encyclopedia: Water quality and resource development: Hoboken, NJ, Wiley Interscience, John Wiley \& Sons, Inc., 717 p.

Linsley, R.K., Kohler, M.A., and Paulhus, J.L.H., 1975, Hydrology for engineers: New York, McGraw-Hill, Inc., $512 \mathrm{p}$.

Lynch, J.A, and Corbett, E.S., 1990, Evaluation of best management practices for controlling nonpoint pollution from silvicultural operations: Water Resources Bulletin, v. 26, no. 1, p. 41-52.

Markley, M.L., 1962, Soil survey of Gloucester County, New Jersey: U.S. Soil Conservation Service and New Jersey Agricultural Experiment Station, Soil Survey Series 1959 , no. 8,84 p.

Markley, M.L., 1971. Soil survey of Burlington County, New Jersey: Washington, D.C., U.S. Department of Agriculture, Cartographic Division, Soil Conservation Service, 103 p.

Markley, M.L., 1988, Soil survey of Camden County, New Jersey: U.S. Department of Agriculture, Soil Conservation Service and New Jersey Agricultural Experiment Station, $94 \mathrm{p}$.

Matter, W.J., and Ney, J.J., 1981, The impact of surface mine reclamation on headwater streams in southwest Virginia: Hydrobiologia, v. 78, p. 63-71.

Metcalf and Eddy, Inc., 1979, Wastewater engineering: Treatment, disposal, reuse: City, Columbus, OH, McGraw Hill, $920 \mathrm{p}$.

Mueller, D.K., Hamilton, P.A., Helsel, D.R., Hitt, K.J., and Ruddy, B.C., 1995, Nutrients in ground water and surface water of the United States-An analysis of data through 1992: U.S. Geological Survey Water-Resources Investigations Report 95-4031, 74 p.

Mueller, D.K., and Helsel, D.R., 1999, Nutrients in the nation's waters - too much of a good thing?: U.S. Geological Survey Circular 1136, 24 p. 
National Research Council, 1979, Ammonia, Committee on Medical and Biological Effects of Environmental Pollutants, Subcommittee on Ammonia: Baltimore, MD, University Park Press, 384 p.

New Jersey Department of Environmental Protection and Energy, 1993, New Jersey 1992 State water quality inventory report: Trenton, N.J., New Jersey Department of Environmental Protection and Energy, 188 p.

New Jersey Department of Environmental Protection, 1998, New Jersey 1998 State water quality inventory report: Trenton, N.J., New Jersey Department of Environmental Protection, sections separately paginated, accessed August 6, 2001, at http://www.state.nj.us/dep/dsr/watershed/305main.htm.

New Jersey Department of Environmental Protection, 2000, 1995/97 Landuse/Landcover by watershed management area (WMA): New Jersey Department of Environmental Protection, 2003, N.J.A.C 7, Chapter 9 B, Surface Water Quality Standards, 127 p., accessed March 15, 2006, at http://www.state.nj.us/dep/dsr/map-integration/LULC95. htm.

New Jersey Department of Environmental Protection, 2004, Amendment to the Tri-County Water Quality Management Plan total maximum daily loads for total phosphorus to address four streams segments and two lakes in Cooper River watershed, Camden County, Lower Delaware Water Region: Trenton, N.J., New Jersey Department of Environmental Protection, $80 \mathrm{p}$.

New Jersey Department of Environmental Protection, 2008, N.J.A.C. 7:9B, Surface Water Quality Standards, Statutory Authority: N.J.S.A. 58: 10A-1 et seq., 58:11A-1 et seq., and 13:1D-1 et seq., date last amended: June 16, 2008 (40 N.J.R. 3630(b)): Trenton, N.J., New Jersey Department of Environmental Protection. (available on the World Wide Web at http://www.state.nj.us/dep/wms/bwqsa/docs/0608 SWQS.pdf).

New Jersey Department of Environmental Protection, 2009, Department approved watershed-based implementation plans: Trenton, N.J., New Jersey Department of Environmental Protection, 2 p. (available at http://www.state.nj.us/ dep/watershedmgt/319watershedbased_plan_implementation_projects.htm).

Rantz, S.E., and others, 1982, Measurement and computation of streamflow: U.S. Geological Survey Water-Supply Paper 2175 , v. 1, Measurement of stage and discharge, and v. 2, Computation of discharge, $631 \mathrm{p}$.
Rasmussen, T.J., Ziegler, A.C., and Rasmussen, P.P., 2005, Estimation of constituent concentrations, densities, loads, and yields in Lower Kansas River, northeast Kansas, using regression models and continuous water-quality monitoring, January 2000 through December 2003: U.S. Geological Survey Scientific Investigations Report 2005-5165, 117 p.

Rasmussen, P.P., and Christensen, V.G., 2005, Hydrologic and water-quality conditions in the Kansas River, northeast Kansas, November 2001-August 2002, and simulation of ammonia assimilative capacity and bacteria transport during low flow: U.S. Geological Survey Scientific Investigations Report 2005-5188.

Rast, W., and Thornton, J.A., 1996, Trends in eutrophication research and control: Hydrological Processes, v. 10, p. 295-313.

Redfield, A., 1958, The biological control of chemical factors in the environment: American Scientist, v. 46, p. 205-221.

Ruffner, J. A., and Bair, F.E., eds., 1977, The weather almanac: Detroit, Michigan, Gale Research Co., 842 p.

Schornick, J.C., Jr., and Fishel, D.K., 1980, Effects of storm runoff on water quality in the Mill Creek drainage basin, Willingboro, New Jersey: U.S. Geological Survey WaterResources Investigations Report 80-98, 111 p.

Seddon, J.A., 1900, River hydraulics: Transactions of the American Society of Civil Engineers, v. 43, p. 179-243.

Senior, L.A., and Koerkle, E.H., 2003, Simulation of streamflow and water quality in the Christina River subbasin and overview of simulations in other subbasins of the Christina River Basin, Pennsylvania, Maryland, and Delaware, 1994-98: U.S. Geological Survey Water-Resources Investigations Report 03-4193,144 p.

Sutton, C.C., O'Herron, J.C., II, Zappalorti, R.T., 1996, The scientific characterization of the Delaware Estuary: Forked River, N.J: Jackson, NJ, Herpetological Associates, Inc., $228 \mathrm{p}$.

U.S. Environmental Protection Agency, 1991, Technical support document for water quality-based toxics control: Washington, D.C., EPA/505/2-90-001, 335 p.

U.S. Environmental Protection Agency, 2000, Stormwater Phase II final rule, small MS4 stormwater program overview: Washington, D.C., EPA 833-F-00-002, 3 p.

U.S. Environmental Protection Agency, 2004, Clean Waters Act Section 319: Laws, Regulations, Treaties, 33, USC Section 1329, January 24, 2004: Washington, D.C., U.S. Environmental Protection Agency, 8 p. 
U.S. Geological Survey, 1986, Land use and land cover digital data from 1:250,000- and 1:100,000-scale maps: U.S. Geological Survey National Mapping Program Technical Instructions: Data users guide 4, $36 \mathrm{p}$.

Velnich, A., 1982, Drainage Areas in New Jersey: Delaware River Basin and streams tributary to Delaware Bay: U.S. Geological Survey Open-File Report 82-572, 48 p.

Vitousek, P.M., Jaber, J.D., Howarth, R.W., Likens, G.E., Matson, P.A., Schindler, D.W., Schlesinger, W.H., and Tilman, D.G., 1997, Human alteration of the global nitrogen cycle: sources and consequences: Ecological Applications, v. 7, no. 3 , p. 737-750.

Walker, W.J., and Branham, B., 1992, Environmental impacts of turfgrass fertilization, in Balogh, J.C., and Walker, W.J., eds., Golf course management and construction: Chelsea, MI, Environmental issues, p. 105-219.

Walter, D.A., LeBlanc, D.R., Stollenwerk, K.G., and Campo, K.W., 1999, Phosphorus transport in sewage-contaminated ground water, Massachusetts Military Reservation, Cape Cod, Massachusetts, in Morganwalp, D.W., and Buxton, H.T., eds., U.S. Geological Survey Toxic Substances Hydrology Program-Proceedings of the Technical Meeting, Charleston, South Carolina, March 8-12, 1999-Volume 3 of 3-Subsurface Contamination from Point Sources: U.S. Geological Survey Water-Resources Investigations Report 99-4018C, p. 305-315.

Wassmann, P., and Olli, K., eds., 2004, Drainage basin nutrient inputs and eutrophication: an integrated approach: Tromsø, Norway, University of Tromsø, ISBN 82-91086-36-2, $325 \mathrm{p}$.

Watt, M.K., 2000, A hydrologic primer for New Jersey watershed management: U.S. Geological Survey WaterResources Investigations Report 2000-4140, 108 p.

Weckström, K., Korhola, A., and Weckström, J., 2007, Impacts of eutrophication on diatom life forms and species richness in coastal waters of the Baltic Sea, AMBIO: A Journal of the Human Environment, v. 36, no. 2, p. 155-160.

Whiley, A.J., 2009, Land use, impervious surface, and water quality, City of Redmond: Olympia, Washington, Water Quality Program, Washington State Department of Ecology, Publication no. 09-10-033, 84 p. (available at http://www. ecy.wa.gov/biblio/0910033.html).

Wilson, D.C., Burns, S.F., Jarrell, W., Lester, A., and Larson, E., 1999, Natural ground-water discharge of orthophosphate in the Tualatin Basin, northwest Oregon: Environmental and Engineering Geoscience, v. 5, no. 2, p. 189-197.

Zar, J.H., 1974, Biostatistical analysis: Englewood Cliffs, N.J., Prentice-Hall, Inc., 619 p.
Zhao S.C., 2004, Mechanisms of lake eutrophication and technologies for controlling in China: Advance in Earth Sciences, v. 19, no. 1, p. 138-140. 


\section{Appendix 1. Summary statistics for concentrations and yields of selected constituents, by base flow, stormflow, growing season, and nongrowing season, in samples from six streams in the lower Delaware River Basin, New Jersey, years 2002-07.}

[Concentrations are in micrograms per liter except bacteria, which are in most probable number per deciliter; yields are in pounds per day per square mile; site locations are given in Fig. 2] 
Appendix 1. Summary statistics for concentrations and yields of selected constituents, by base flow, stormflow, growing season, and nongrowing season, in samples from six streams in the lower Delaware River Basin, New Jersey, years 2002-07.

[Concentrations are in micrograms per liter except bacteria, which are in most probable number per deciliter; yields are in pounds per day per square mile; site locations are given in Fig. 2]

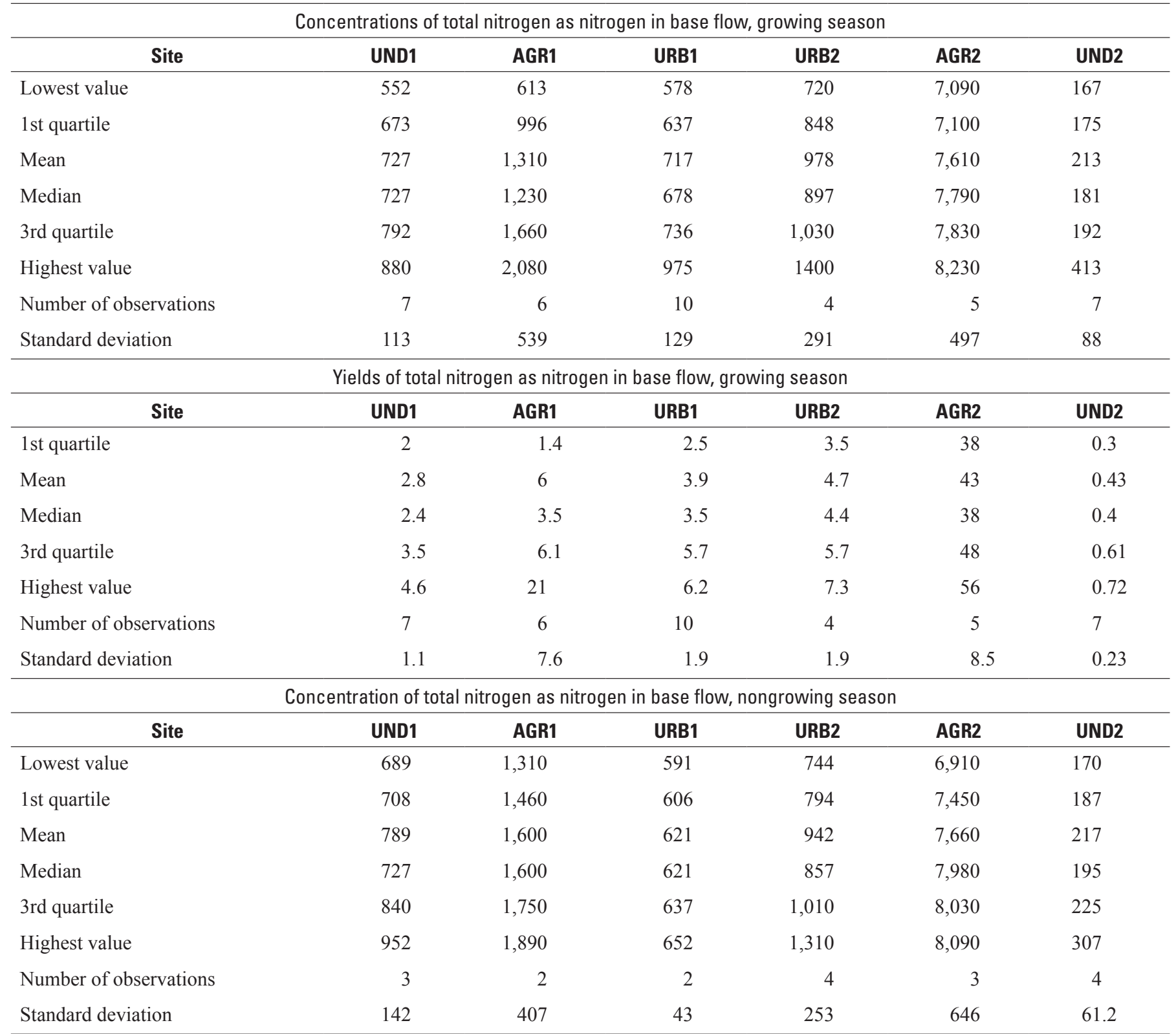

\begin{tabular}{|c|c|c|c|c|c|c|}
\hline \multicolumn{7}{|c|}{ Yields of total nitrogen as nitrogen in base flow, nongrowing season } \\
\hline Lowest value & 4.4 & 9.4 & 3 & 4.2 & 43 & 0.6 \\
\hline 1st quartile & 5.1 & 9.7 & 3.4 & 4.6 & 48 & 0.64 \\
\hline Mean & 5.7 & 9.9 & 3.8 & 5.3 & 51 & 0.73 \\
\hline Highest value & 6.9 & 10 & 4.6 & 6.9 & 55 & 0.91 \\
\hline Number of observations & 3 & 2 & 2 & 4 & 3 & 4 \\
\hline Standard deviation & 1.3 & 0.73 & 1.1 & 1.2 & 6.7 & 0.14 \\
\hline
\end{tabular}


Appendix 1. Summary statistics for concentrations and yields of selected constituents, by base flow, stormflow, growing season, and nongrowing season, in samples from six streams in the lower Delaware River Basin, New Jersey, years 2002-07._Continued

[Concentrations are in micrograms per liter except bacteria, which are in most probable number per deciliter; yields are in pounds per day per square mile; site locations are given in Fig. 2]

\begin{tabular}{|c|c|c|c|c|c|c|}
\hline \multicolumn{7}{|c|}{ Concentration of total nitrogen as nitrogen in stormflow, growing season } \\
\hline Site & UND1 & AGR1 & URB1 & URB2 & AGR2 & UND2 \\
\hline Lowest value & 582 & 742 & 505 & 556 & 4,040 & 173 \\
\hline Mean & 822 & 1,830 & 1,230 & 1,100 & 6,150 & 390 \\
\hline Median & 719 & 1,760 & 988 & 823 & 6,290 & 333 \\
\hline Highest value & 1,660 & 4,150 & 3,740 & 3,400 & 9,310 & 927 \\
\hline Number of observations & 28 & 32 & 30 & 28 & 22 & 21 \\
\hline Standard deviation & 274 & 842 & 726 & 667 & 1340 & 175 \\
\hline \multicolumn{7}{|c|}{ Yield of total nitrogen as nitrogen in stormflow, growing season } \\
\hline Mean & 22 & 49 & 45 & 17 & 120 & 1.9 \\
\hline Median & 7.8 & 27 & 32 & 16 & 77 & 1.7 \\
\hline 3rd quartile & 18 & 38 & 72 & 21 & 130 & 2.2 \\
\hline Highest value & 150 & 250 & 140 & 30 & 320 & 4.7 \\
\hline Number of observations & 28 & 32 & 30 & 28 & 22 & 21 \\
\hline Standard deviation & 35 & 66 & 35 & 6.2 & 86 & 1.2 \\
\hline \multicolumn{7}{|c|}{ Concentration of nitrogen as nitrogen in stormflow, nongrowing season } \\
\hline Site & UND1 & AGR1 & URB1 & URB2 & AGR2 & UND2 \\
\hline Number of observations & 11 & 6 & 12 & 16 & 16 & 18 \\
\hline Standard deviation & 216 & 225 & 542 & 396 & 1,300 & 101 \\
\hline \multicolumn{7}{|c|}{ Yield of total nitrogen as nitrogen in stormflow, nongrowing season } \\
\hline Site & UND1 & AGR1 & URB1 & URB2 & AGR2 & UND2 \\
\hline Lowest value & 6.2 & 14 & 4.9 & 5.2 & 58 & 1 \\
\hline 1st quartile & 8.7 & 17 & 13 & 10 & 71 & 1.5 \\
\hline Mean & 15 & 28 & 33 & 22 & 89 & 2 \\
\hline Median & 11 & 27 & 36 & 12 & 76 & 1.9 \\
\hline 3rd quartile & 17 & 38 & 45 & 31 & 100 & 2.2 \\
\hline Highest value & 42 & 45 & 68 & 67 & 140 & 3.6 \\
\hline Number of observations & 11 & 6 & 12 & 16 & 16 & 18 \\
\hline Standard deviation & 11 & 13 & 20 & 19 & 27 & 0.68 \\
\hline
\end{tabular}


Appendix 1. Summary statistics for concentrations and yields of selected constituents, by base flow, stormflow, growing season, and nongrowing season, in samples from six streams in the lower Delaware River Basin, New Jersey, years 2002-07.-Continued

[Concentrations are in micrograms per liter except bacteria, which are in most probable number per deciliter; yields are in pounds per day per square mile; site locations are given in Fig. 2]

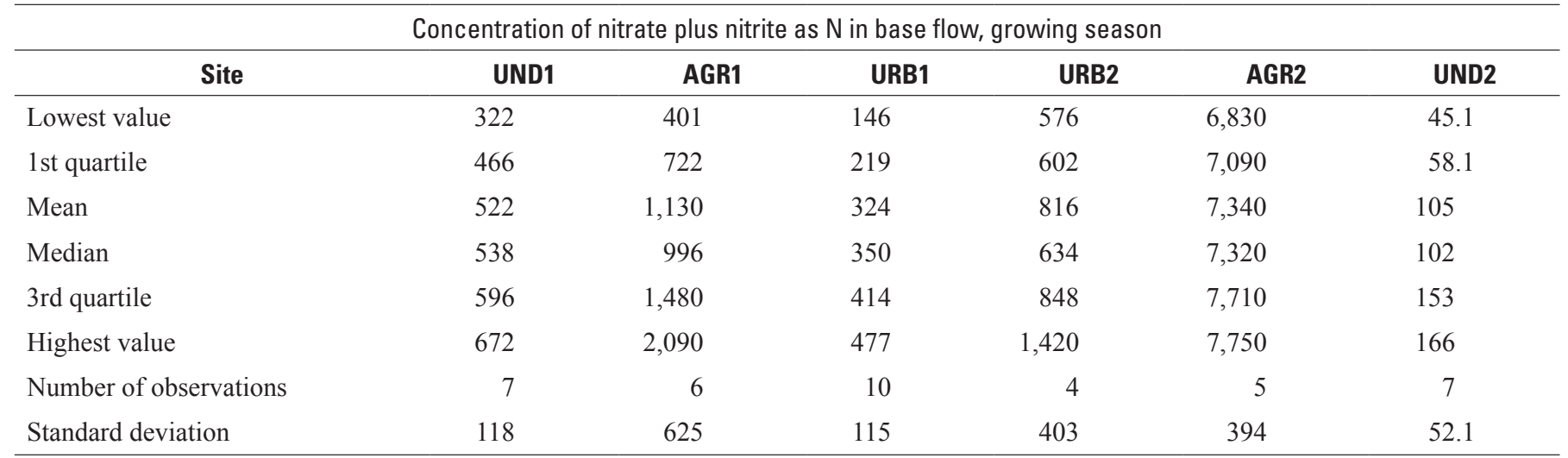

Yield of nitrate plus nitrite as $\mathrm{N}$ in base flow, growing season

\begin{tabular}{|c|c|c|c|c|c|c|}
\hline Site & UND1 & AGR1 & URB1 & URB2 & AGR2 & UND2 \\
\hline Lowest value & 0.94 & 0.33 & 0.72 & 1.9 & 32 & 0.06 \\
\hline 1st quartile & 1.4 & 1 & 0.97 & 2.5 & 36 & 0.12 \\
\hline Median & 1.9 & 2.9 & 1.5 & 3.4 & 37 & 0.18 \\
\hline 3rd quartile & 2.3 & 5.4 & 1.9 & 4.9 & 49 & 0.24 \\
\hline Number of observations & 7 & 6 & 10 & 4 & 5 & 7 \\
\hline Standard deviation & 1.1 & 7.8 & 1.1 & 2.4 & 8.8 & 0.1 \\
\hline
\end{tabular}

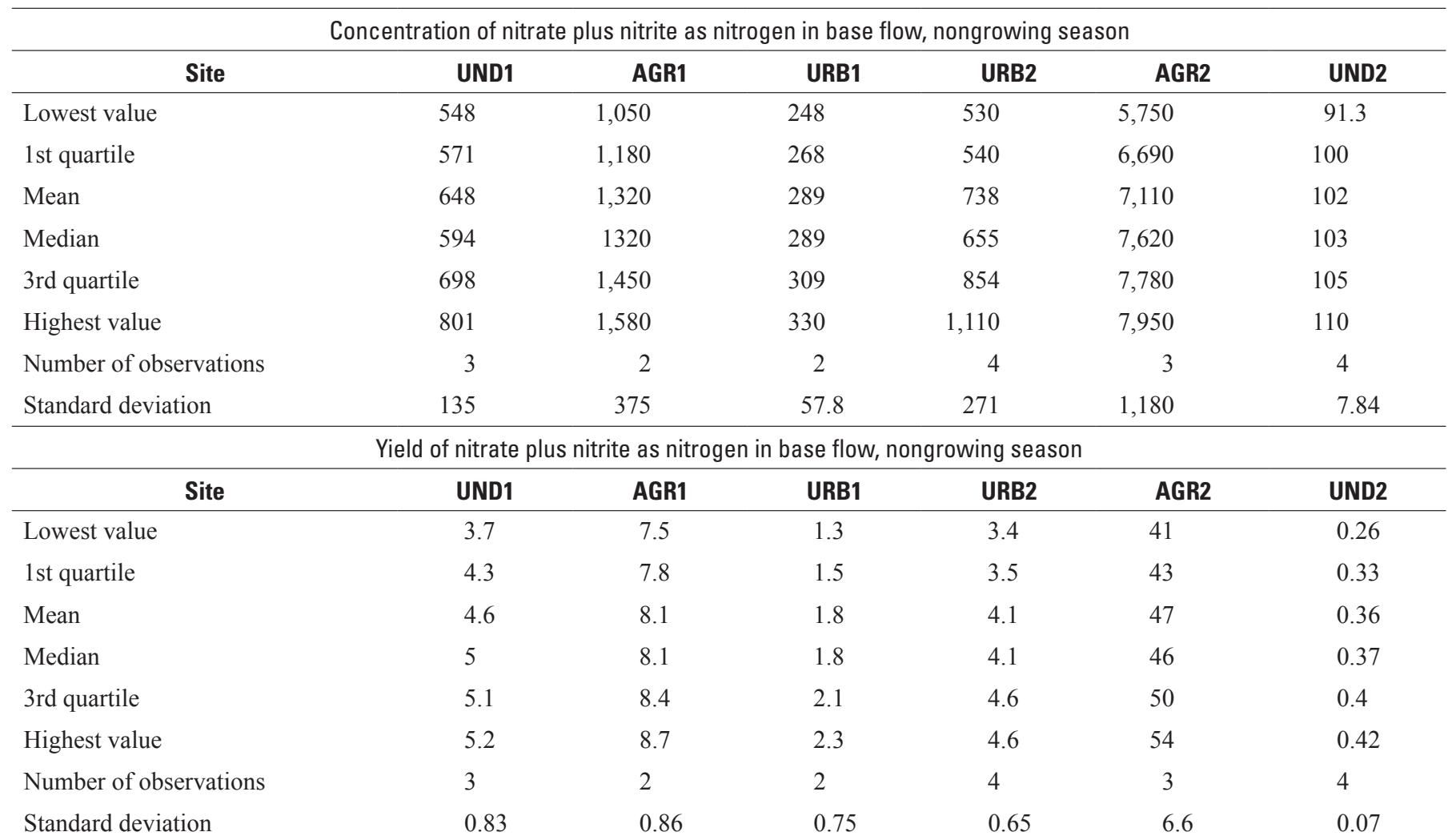


Appendix 1. Summary statistics for concentrations and yields of selected constituents, by base flow, stormflow, growing season, and nongrowing season, in samples from six streams in the lower Delaware River Basin, New Jersey, years 2002-07._Continued

[Concentrations are in micrograms per liter except bacteria, which are in most probable number per deciliter; yields are in pounds per day per square mile; site locations are given in Fig. 2]

\begin{tabular}{|c|c|c|c|c|c|c|}
\hline \multicolumn{7}{|c|}{ Concentration of nitrate plus nitrite as nitrogen in stormflow, growing season } \\
\hline Site & UND1 & AGR1 & URB1 & URB2 & AGR2 & UND2 \\
\hline Lowest value & 308 & 376 & 110 & 209 & 2,000 & 170 \\
\hline Mean & 430 & 925 & 358 & 433 & 4,100 & 410 \\
\hline Median & 415 & 869 & 355 & 422 & 3,410 & 300 \\
\hline Highest value & 605 & 1,620 & 570 & 775 & 7,450 & 1,070 \\
\hline Number of observations & 28 & 32 & 30 & 28 & 22 & 21 \\
\hline Standard deviation & 86.6 & 372 & 111 & 156 & 1,700 & 260 \\
\hline
\end{tabular}

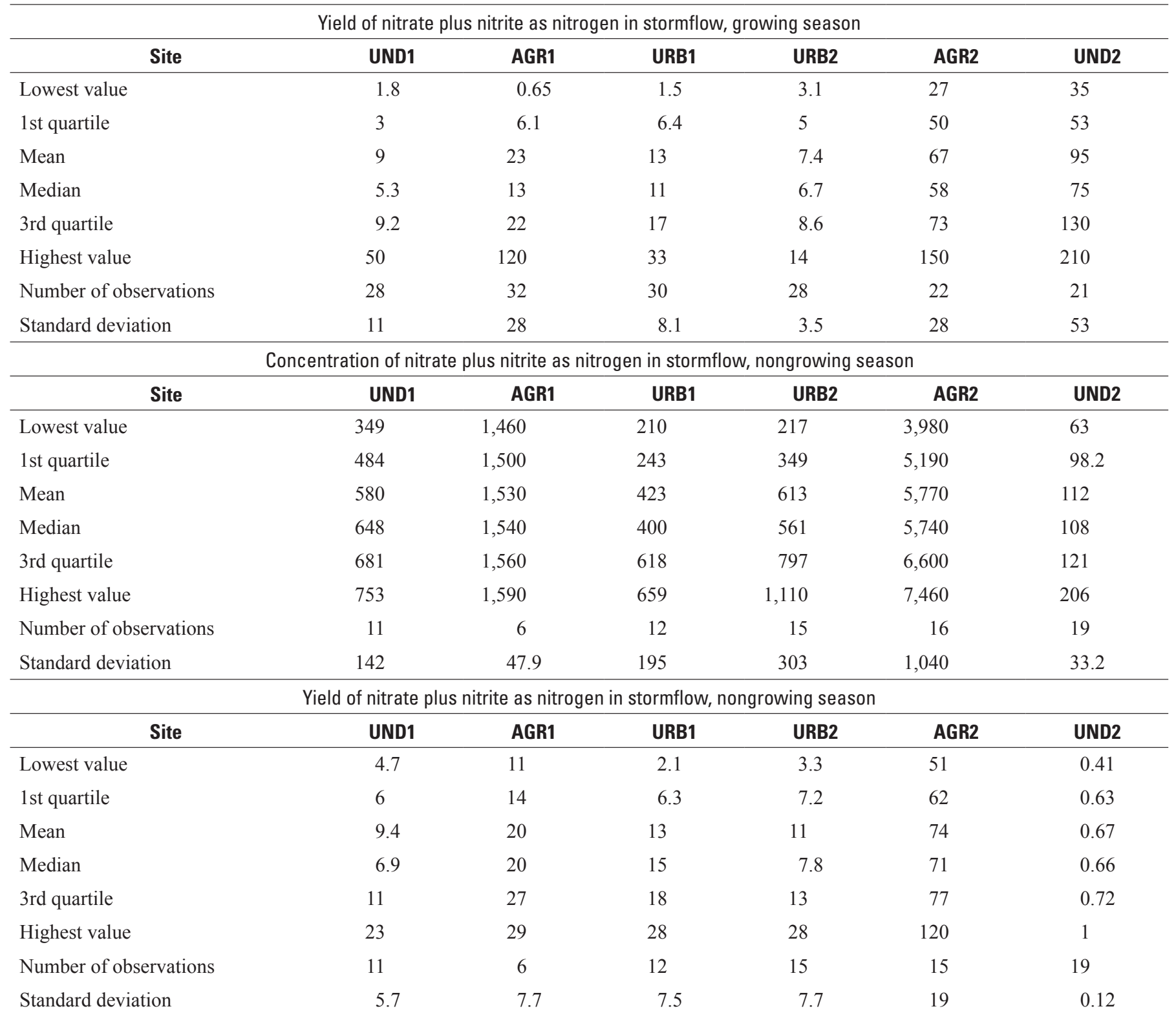


Appendix 1. Summary statistics for concentrations and yields of selected constituents, by base flow, stormflow, growing season, and nongrowing season, in samples from six streams in the lower Delaware River Basin, New Jersey, years 2002-07.-Continued

[Concentrations are in micrograms per liter except bacteria, which are in most probable number per deciliter; yields are in pounds per day per square mile; site locations are given in Fig. 2]

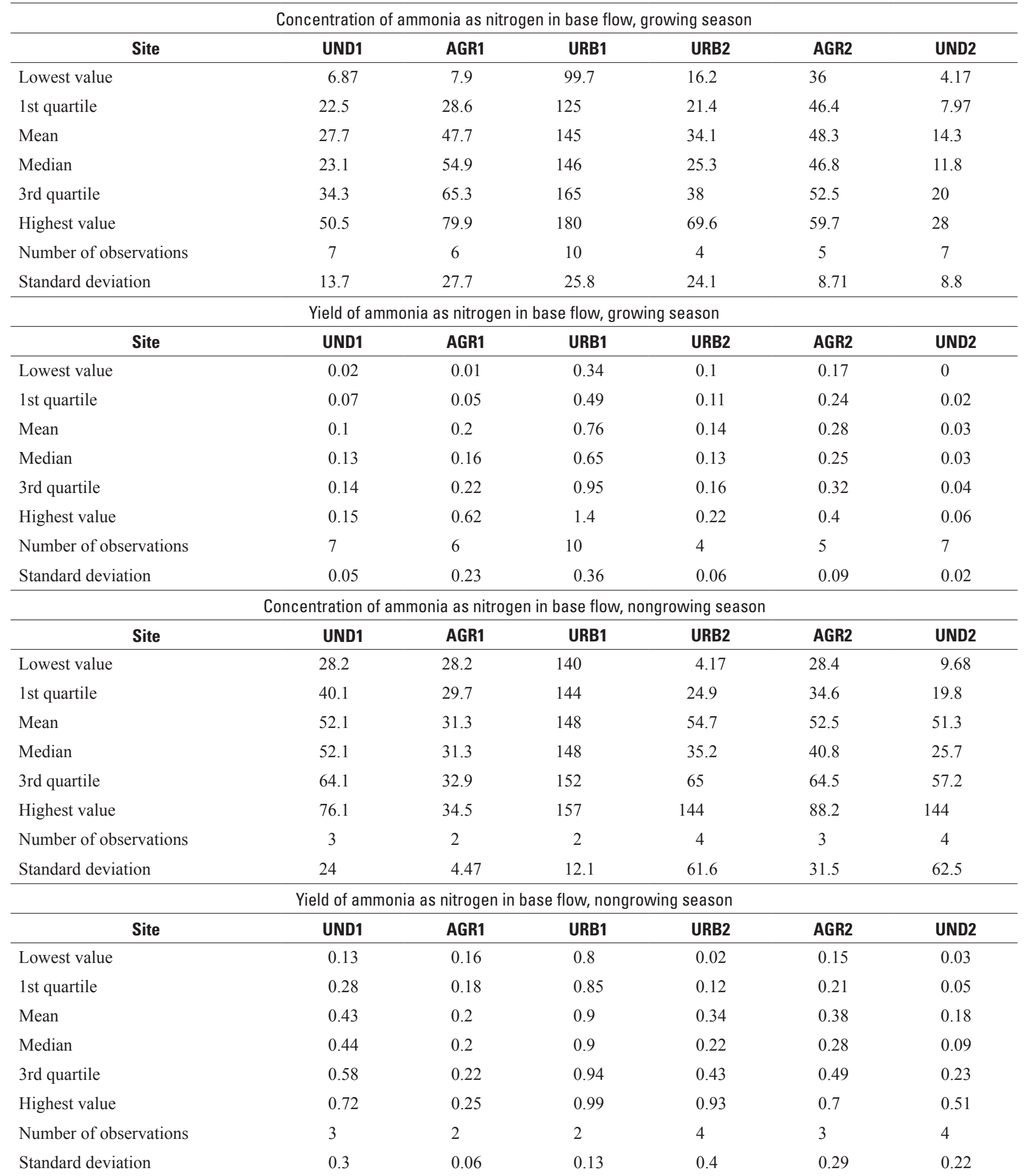


Appendix 1. Summary statistics for concentrations and yields of selected constituents, by base flow, stormflow, growing season, and nongrowing season, in samples from six streams in the lower Delaware River Basin, New Jersey, years 2002-07._Continued

[Concentrations are in micrograms per liter except bacteria, which are in most probable number per deciliter; yields are in pounds per day per square mile; site locations are given in Fig. 2]

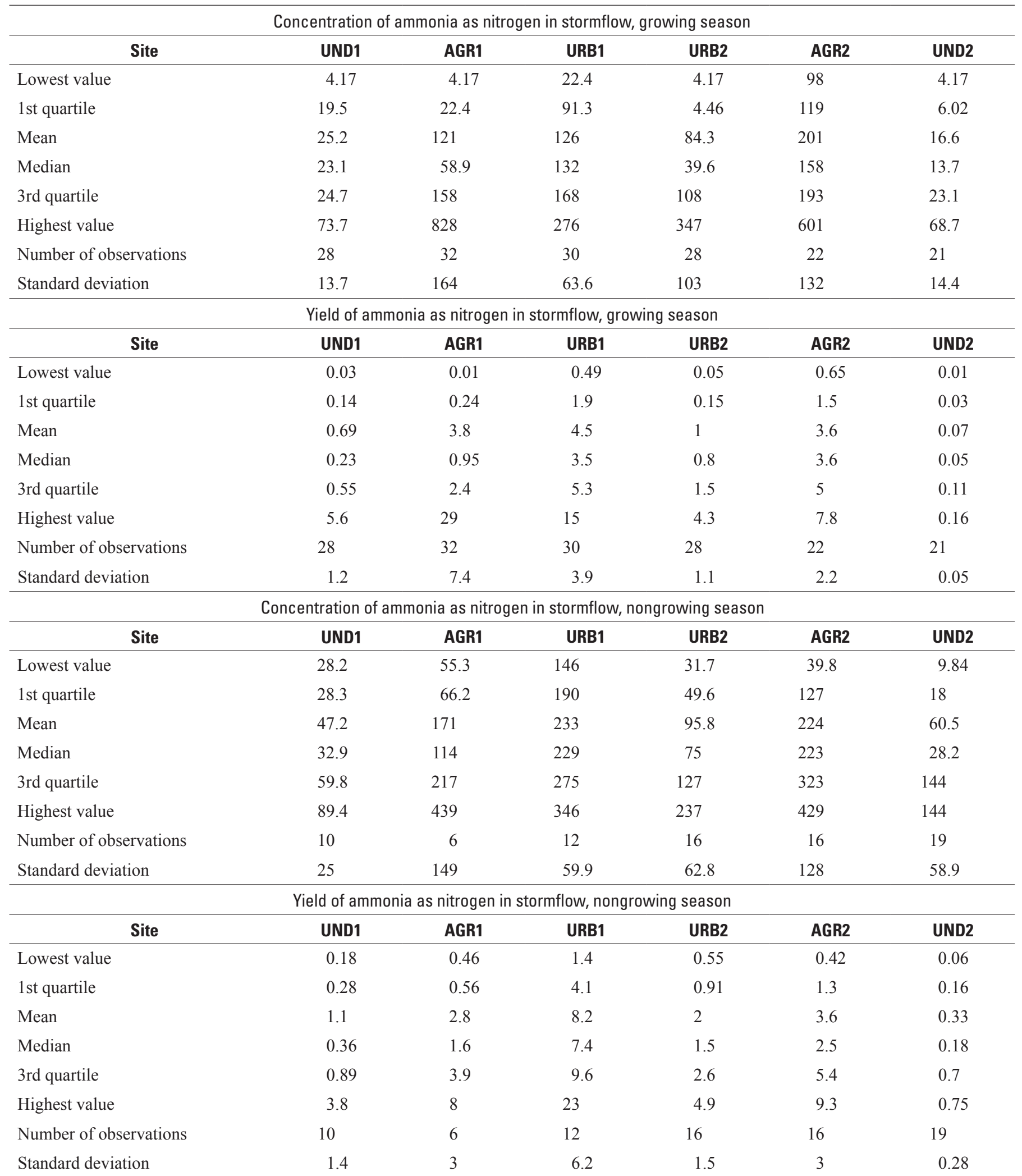


Appendix 1. Summary statistics for concentrations and yields of selected constituents, by base flow, stormflow, growing season, and nongrowing season, in samples from six streams in the lower Delaware River Basin, New Jersey, years 2002-07.-Continued

[Concentrations are in micrograms per liter except bacteria, which are in most probable number per deciliter; yields are in pounds per day per square mile; site locations are given in Fig. 2]

\begin{tabular}{|c|c|c|c|c|c|c|}
\hline \multicolumn{7}{|c|}{ Concentration of Organic nitrogen as nitrogen in base flow, growing season } \\
\hline Site & UND1 & AGR1 & URB1 & URB2 & AGR2 & UND2 \\
\hline Lowest value & 33.7 & ND & 32.6 & 143 & ND & 6.33 \\
\hline Mean & 178 & 151 & 254 & 192 & 251 & 96.9 \\
\hline Median & 181 & 184 & 182 & 211 & 237 & 99 \\
\hline Highest value & 328 & 271 & 737 & 222 & 645 & 239 \\
\hline Number of observations & 7 & 6 & 10 & 3 & 5 & 7 \\
\hline Standard deviation & 87 & 124 & 243 & 42.7 & 344 & 74.5 \\
\hline \multicolumn{7}{|c|}{ Yield of Organic nitrogen as nitrogen in base flow, growing season } \\
\hline Mean & 0.64 & 0.41 & 1.5 & 0.87 & 2.1 & 0.22 \\
\hline Median & 0.52 & 0.34 & 0.75 & 0.92 & 2.1 & 0.24 \\
\hline 3rd quartile & 0.69 & 0.39 & 2.6 & 0.97 & 3 & 0.32 \\
\hline Highest value & 1.4 & 0.86 & 4 & 1 & 3 & 0.42 \\
\hline Number of observations & 7 & 5 & 10 & 3 & 4 & 7 \\
\hline Standard deviation & 0.37 & 0.27 & 1.6 & 0.18 & 1 & 0.16 \\
\hline \multicolumn{7}{|c|}{ Concentration of Organic nitrogen as nitrogen in base flow, nongrowing season } \\
\hline Site & UND1 & AGR1 & URB1 & URB2 & AGR2 & UND2 \\
\hline Number of observations & 3 & 2 & 2 & 4 & 3 & 4 \\
\hline Standard deviation & 26.2 & 13.7 & 11.9 & 78.5 & 815 & 110 \\
\hline \multicolumn{7}{|c|}{ Yield of Organic nitrogen as nitrogen in base flow, nongrowing season } \\
\hline Site & UND1 & AGR1 & URB1 & URB2 & AGR2 & UND2 \\
\hline Lowest value & 0.57 & 1.5 & 1 & 0.45 & ND & ND \\
\hline 1st quartile & 0.6 & 1.6 & 1.1 & 0.57 & 4.9 & 0.32 \\
\hline Mean & 0.77 & 1.7 & 1.2 & 0.98 & 7.4 & 0.36 \\
\hline Median & 0.63 & 1.7 & 1.2 & 0.64 & 7.4 & 0.36 \\
\hline 3rd quartile & 0.87 & 1.8 & 1.2 & 1.1 & 10 & 0.41 \\
\hline Highest value & 1.1 & 1.9 & 1.3 & 2.2 & 13 & 0.45 \\
\hline Number of observations & 3 & 2 & 2 & 4 & 3 & 4 \\
\hline Standard deviation & 0.29 & 0.23 & 0.19 & 0.81 & 7.2 & 0.08 \\
\hline
\end{tabular}


Appendix 1. Summary statistics for concentrations and yields of selected constituents, by base flow, stormflow, growing season, and nongrowing season, in samples from six streams in the lower Delaware River Basin, New Jersey, years 2002-07._-Continued

[Concentrations are in micrograms per liter except bacteria, which are in most probable number per deciliter; yields are in pounds per day per square mile; site locations are given in Fig. 2]

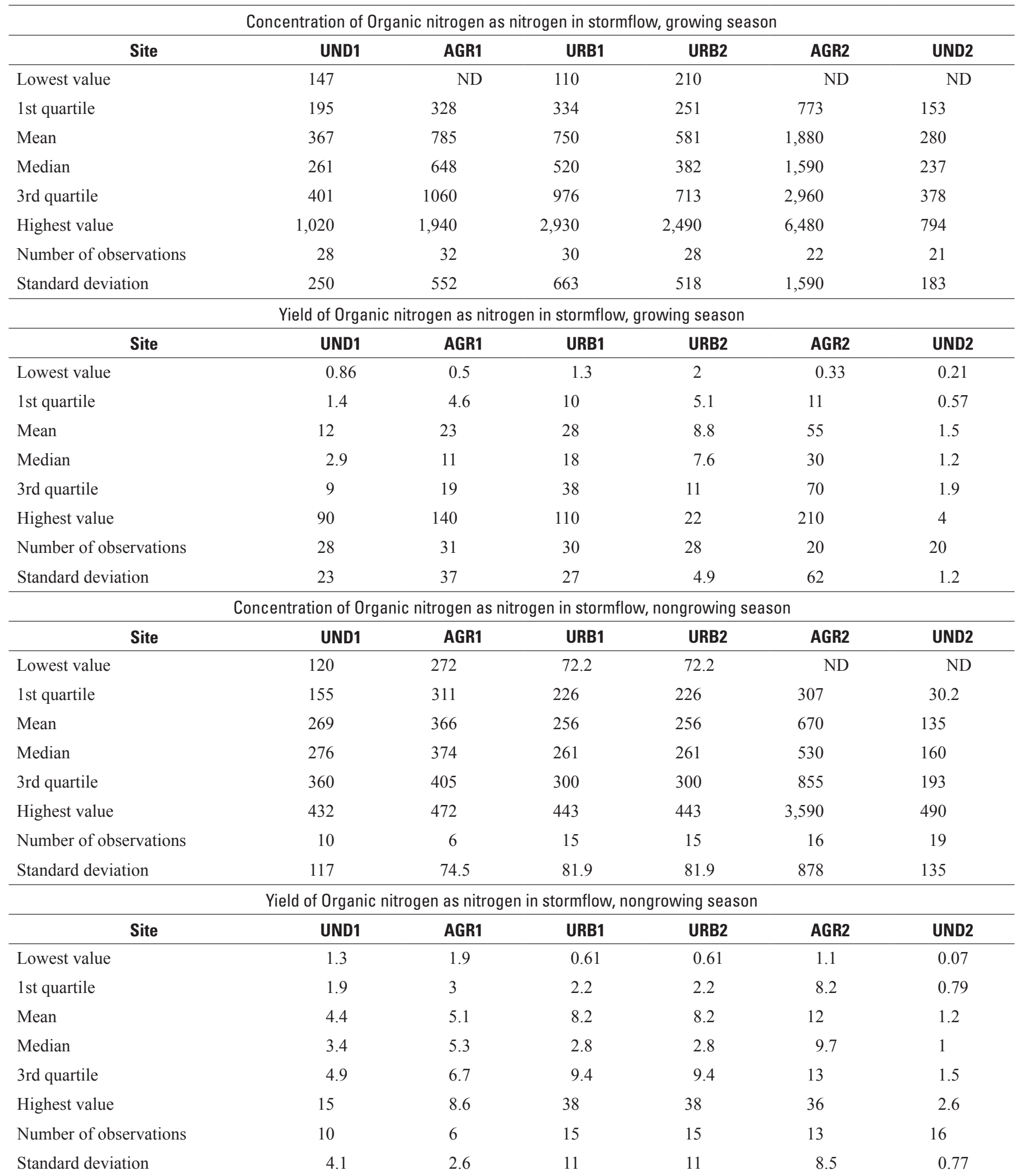


Appendix 1. Summary statistics for concentrations and yields of selected constituents, by base flow, stormflow, growing season, and nongrowing season, in samples from six streams in the lower Delaware River Basin, New Jersey, years 2002-07.-Continued

[Concentrations are in micrograms per liter except bacteria, which are in most probable number per deciliter; yields are in pounds per day per square mile; site locations are given in Fig. 2]

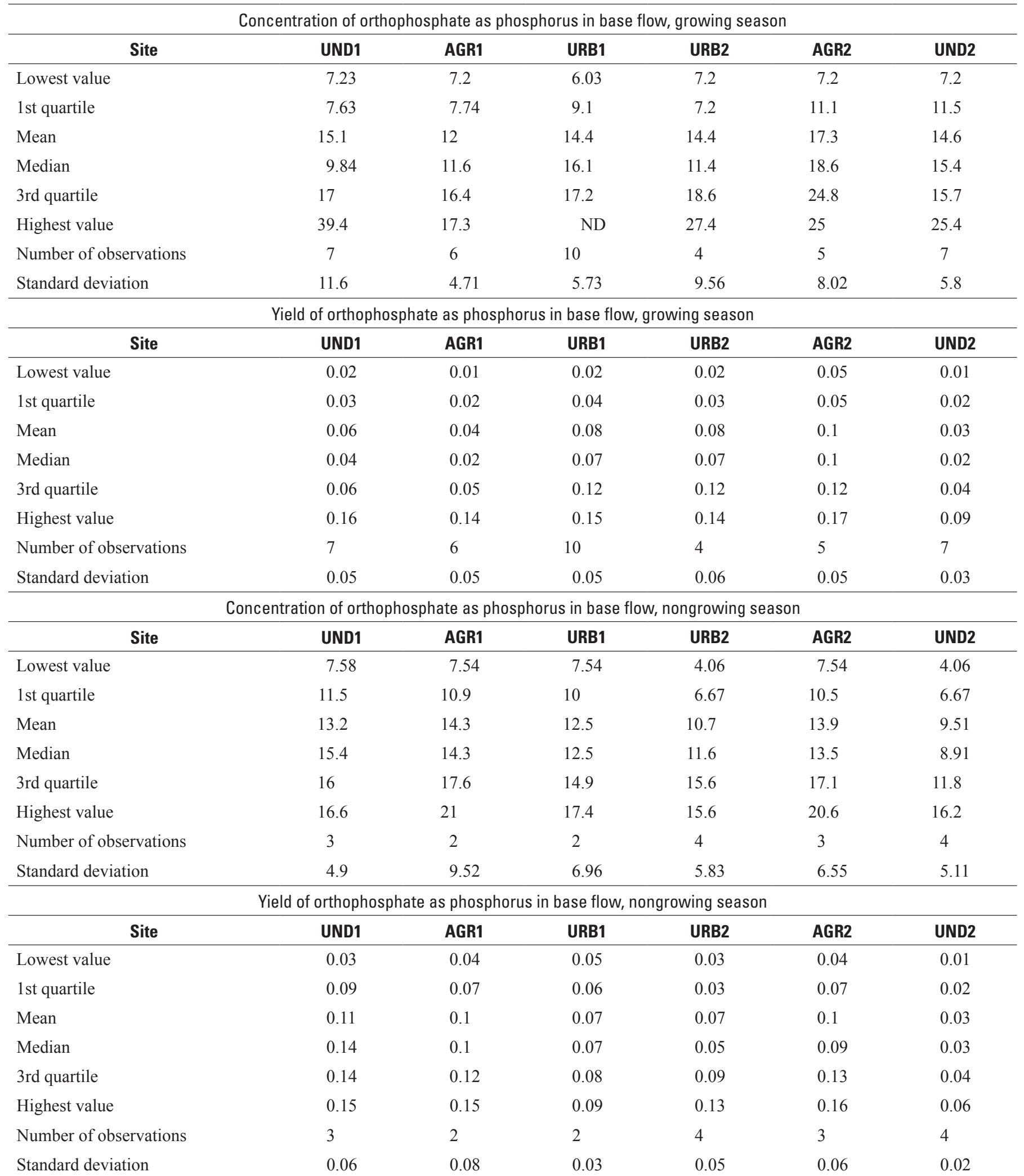


Appendix 1. Summary statistics for concentrations and yields of selected constituents, by base flow, stormflow, growing season, and nongrowing season, in samples from six streams in the lower Delaware River Basin, New Jersey, years 2002-07._Continued

[Concentrations are in micrograms per liter except bacteria, which are in most probable number per deciliter; yields are in pounds per day per square mile; site locations are given in Fig. 2]

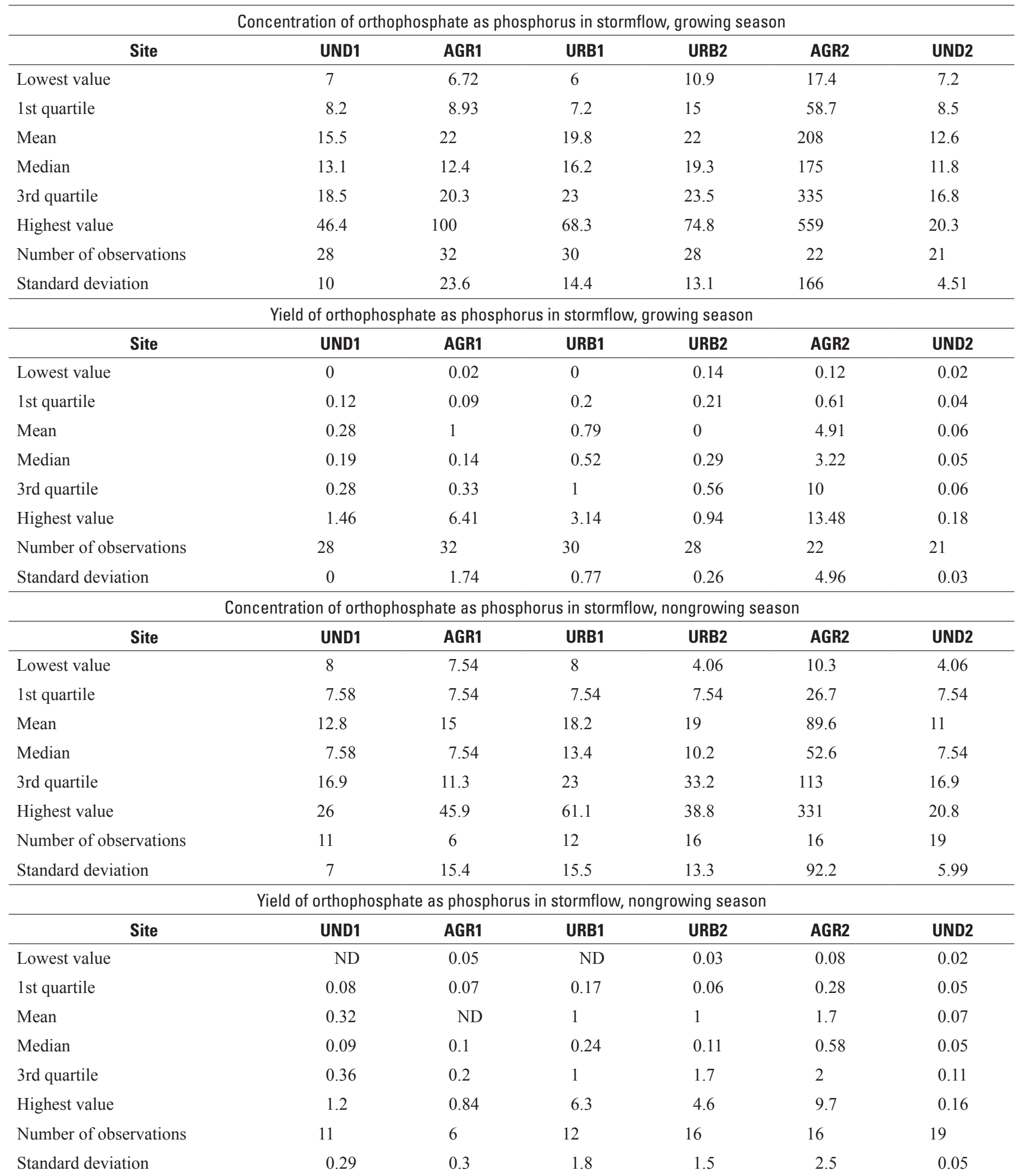


Appendix 1. Summary statistics for concentrations and yields of selected constituents, by base flow, stormflow, growing season, and nongrowing season, in samples from six streams in the lower Delaware River Basin, New Jersey, years 2002-07.-Continued

[Concentrations are in micrograms per liter except bacteria, which are in most probable number per deciliter; yields are in pounds per day per square mile; site locations are given in Fig. 2]

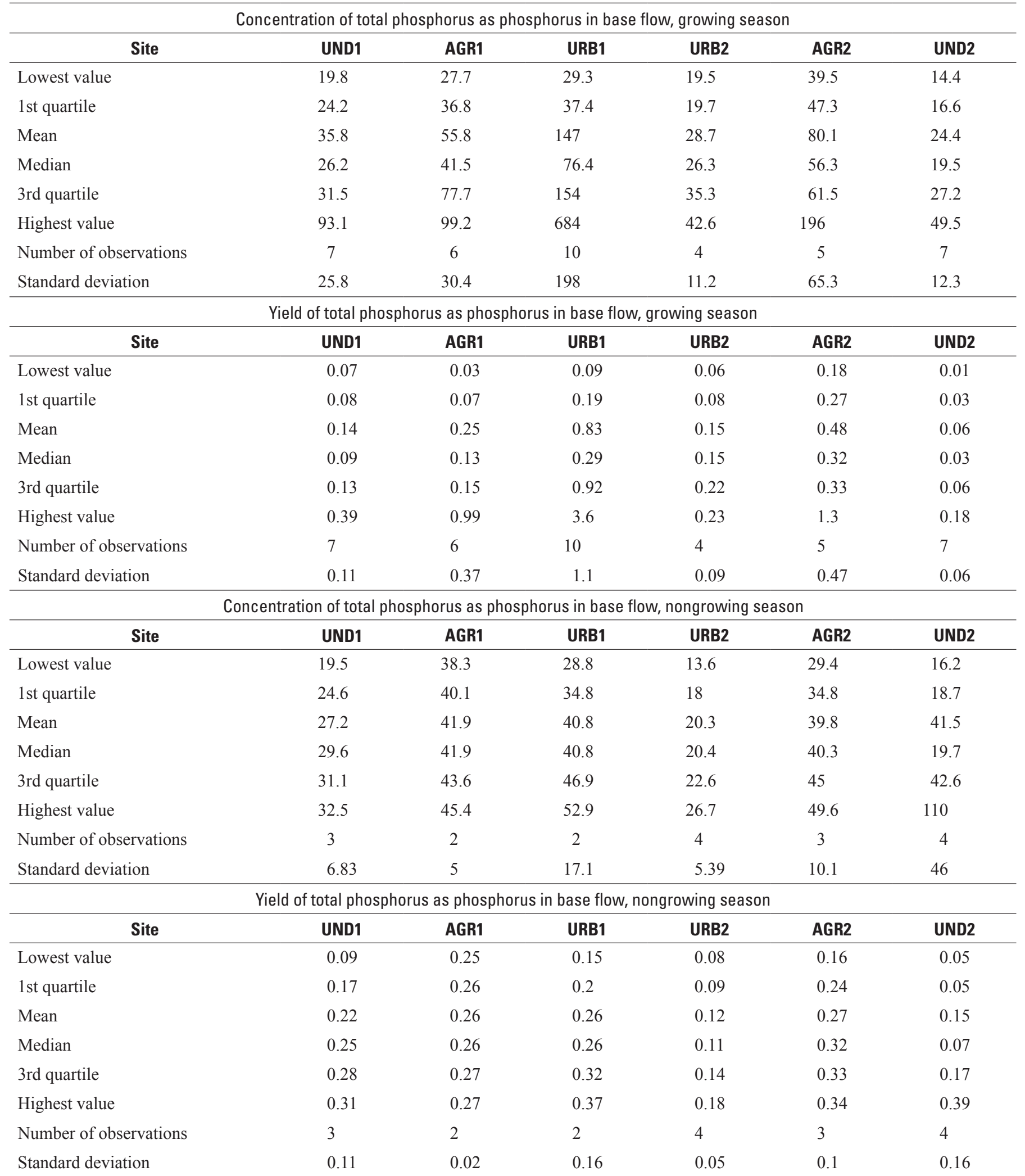


Appendix 1. Summary statistics for concentrations and yields of selected constituents, by base flow, stormflow, growing season, and nongrowing season, in samples from six streams in the lower Delaware River Basin, New Jersey, years 2002-07._Continued

[Concentrations are in micrograms per liter except bacteria, which are in most probable number per deciliter; yields are in pounds per day per square mile; site locations are given in Fig. 2]

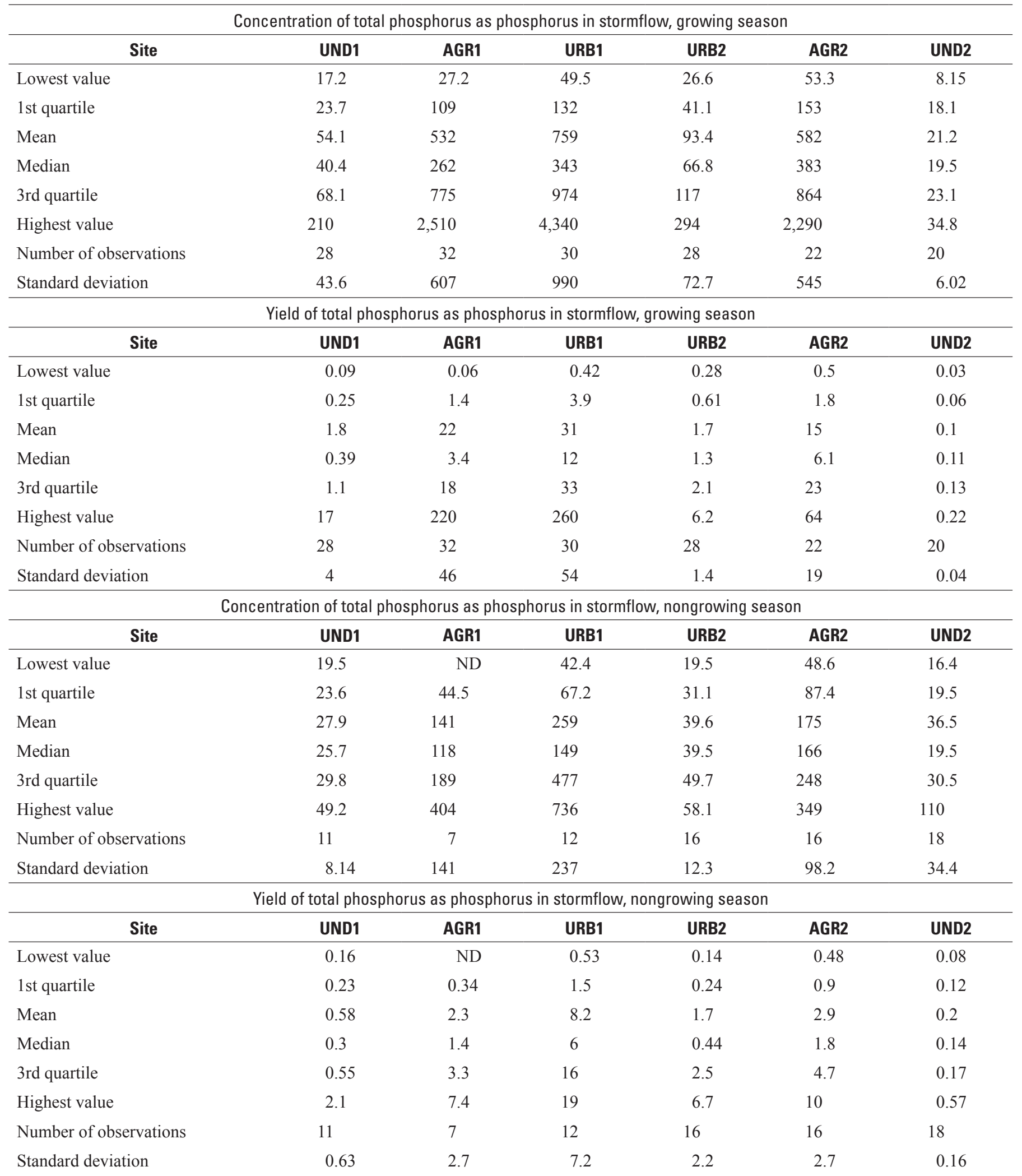


Appendix 1. Summary statistics for concentrations and yields of selected constituents, by base flow, stormflow, growing season, and nongrowing season, in samples from six streams in the lower Delaware River Basin, New Jersey, years 2002-07.-Continued

[Concentrations are in micrograms per liter except bacteria, which are in most probable number per deciliter; yields are in pounds per day per square mile; site locations are given in Fig. 2]

\begin{tabular}{|c|c|c|c|c|c|c|}
\hline \multicolumn{7}{|c|}{ Concentration of fecal coliform in base flow, growing season } \\
\hline Site & UND1 & AGR1 & URB1 & URB2 & AGR2 & UND2 \\
\hline Lowest value & $3.00 \mathrm{E}+0$ & $7.00 \mathrm{E}+0$ & $1.10 \mathrm{E}+2$ & $3.00 \mathrm{E}+0$ & $3.10 \mathrm{E}+2$ & $1.00 \mathrm{E}+1$ \\
\hline Mean & $3.73 \mathrm{E}+3$ & $2.57 \mathrm{E}+2$ & $4.55 \mathrm{E}+3$ & $7.08 \mathrm{E}+1$ & $2.59 \mathrm{E}+3$ & $1.94 \mathrm{E}+2$ \\
\hline Median & $3.00 \mathrm{E}+1$ & $1.75 \mathrm{E}+2$ & $3.64 \mathrm{E}+2$ & $7.50 \mathrm{E}+1$ & $2.40 \mathrm{E}+3$ & $6.30 \mathrm{E}+1$ \\
\hline Highest value & $2.58 \mathrm{E}+4$ & $7.27 \mathrm{E}+2$ & $1.70 \mathrm{E}+4$ & $1.30 \mathrm{E}+2$ & $5.80 \mathrm{E}+3$ & $9.00 \mathrm{E}+2$ \\
\hline Number of observations & 7 & 6 & 10 & 4 & 5 & 7 \\
\hline Standard deviation & $9.73 \mathrm{E}+3$ & $2.51 \mathrm{E}+2$ & $6.57 \mathrm{E}+3$ & $5.35 \mathrm{E}+1$ & $2.16 \mathrm{E}+3$ & $3.23 \mathrm{E}+2$ \\
\hline \multicolumn{7}{|c|}{ Yield of fecal coliform in base flow, growing season } \\
\hline Mean & $7.01 \mathrm{E}+10$ & $1.91 \mathrm{E}+9$ & $1.16 \mathrm{E}+11$ & $1.67 \mathrm{E}+9$ & $6.22 \mathrm{E}+10$ & $2.37 \mathrm{E}+9$ \\
\hline Median & $1.44 \mathrm{E}+8$ & $2.42 \mathrm{E}+9$ & $5.84 \mathrm{E}+9$ & $1.26 \mathrm{E}+9$ & $6.97 \mathrm{E}+10$ & $2.05 \mathrm{E}+8$ \\
\hline 3rd quartile & $2.00 \mathrm{E}+9$ & $2.59 \mathrm{E}+9$ & $1.97 \mathrm{E}+11$ & $2.27 \mathrm{E}+9$ & $7.22 \mathrm{E}+10$ & $1.68 \mathrm{E}+9$ \\
\hline Highest value & $4.86 \mathrm{E}+11$ & $2.67 \mathrm{E}+9$ & $4.12 \mathrm{E}+11$ & $4.09 \mathrm{E}+9$ & $1.37 \mathrm{E}+11$ & $1.27 \mathrm{E}+10$ \\
\hline Number of observations & 7 & 6 & 10 & 4 & 5 & 7 \\
\hline Standard deviation & $1.83 \mathrm{E}+11$ & $9.86 \mathrm{E}+8$ & $1.60 \mathrm{E}+11$ & $1.74 \mathrm{E}+9$ & $5.04 \mathrm{E}+10$ & $4.65 \mathrm{E}+9$ \\
\hline \multicolumn{7}{|c|}{ Concentration of fecal coliform in base flow, nongrowing season } \\
\hline Site & UND1 & AGR1 & URB1 & URB2 & AGR2 & UND2 \\
\hline Number of observations & 3 & 2 & 2 & 4 & 3 & 4 \\
\hline Standard deviation & $5.84 \mathrm{E}+1$ & $1.20 \mathrm{E}+1$ & $1.20 \mathrm{E}+1$ & $4.52 \mathrm{E}+1$ & $5.40 \mathrm{E}+3$ & $5.00 \mathrm{E}+0$ \\
\hline \multicolumn{7}{|c|}{ Yield of fecal coliform in base flow, nongrowing season } \\
\hline Site & UND1 & AGR1 & URB1 & URB2 & AGR2 & UND2 \\
\hline Lowest value & $6.25 \mathrm{E}+7$ & $7.37 \mathrm{E}+7$ & $6.85 \mathrm{E}+8$ & $1.85 \mathrm{E}+8$ & $1.35 \mathrm{E}+9$ & $1.10 \mathrm{E}+8$ \\
\hline 1st quartile & $6.02 \mathrm{E}+8$ & $2.14 \mathrm{E}+8$ & $8.84 \mathrm{E}+8$ & $3.30 \mathrm{E}+8$ & $1.31 \mathrm{E}+11$ & $1.41 \mathrm{E}+8$ \\
\hline Mean & $2.06 \mathrm{E}+9$ & $3.55 \mathrm{E}+8$ & $1.08 \mathrm{E}+9$ & $1.19 \mathrm{E}+9$ & $2.06 \mathrm{E}+11$ & $1.96 \mathrm{E}+8$ \\
\hline Median & $1.14 \mathrm{E}+9$ & $3.55 \mathrm{E}+8$ & $1.08 \mathrm{E}+9$ & $1.20 \mathrm{E}+9$ & $2.62 \mathrm{E}+11$ & $1.79 \mathrm{E}+8$ \\
\hline 3rd quartile & $3.05 \mathrm{E}+9$ & $4.96 \mathrm{E}+8$ & $1.28 \mathrm{E}+9$ & $2.06 \mathrm{E}+9$ & $3.08 \mathrm{E}+11$ & $2.33 \mathrm{E}+8$ \\
\hline Highest value & $4.96 \mathrm{E}+9$ & $6.37 \mathrm{E}+8$ & $1.48 \mathrm{E}+9$ & $2.20 \mathrm{E}+9$ & $3.54 \mathrm{E}+11$ & $3.15 \mathrm{E}+8$ \\
\hline Number of observations & 3 & 2 & 2 & 4 & 3 & 4 \\
\hline Standard deviation & $2.58 \mathrm{E}+9$ & $3.98 \mathrm{E}+8$ & $5.62 \mathrm{E}+8$ & $1.06 \mathrm{E}+9$ & $1.83 \mathrm{E}+11$ & $8.86 \mathrm{E}+7$ \\
\hline
\end{tabular}


Appendix 1. Summary statistics for concentrations and yields of selected constituents, by base flow, stormflow, growing season, and nongrowing season, in samples from six streams in the lower Delaware River Basin, New Jersey, years 2002-07.—Continued

[Concentrations are in micrograms per liter except bacteria, which are in most probable number per deciliter; yields are in pounds per day per square mile; site locations are given in Fig. 2]

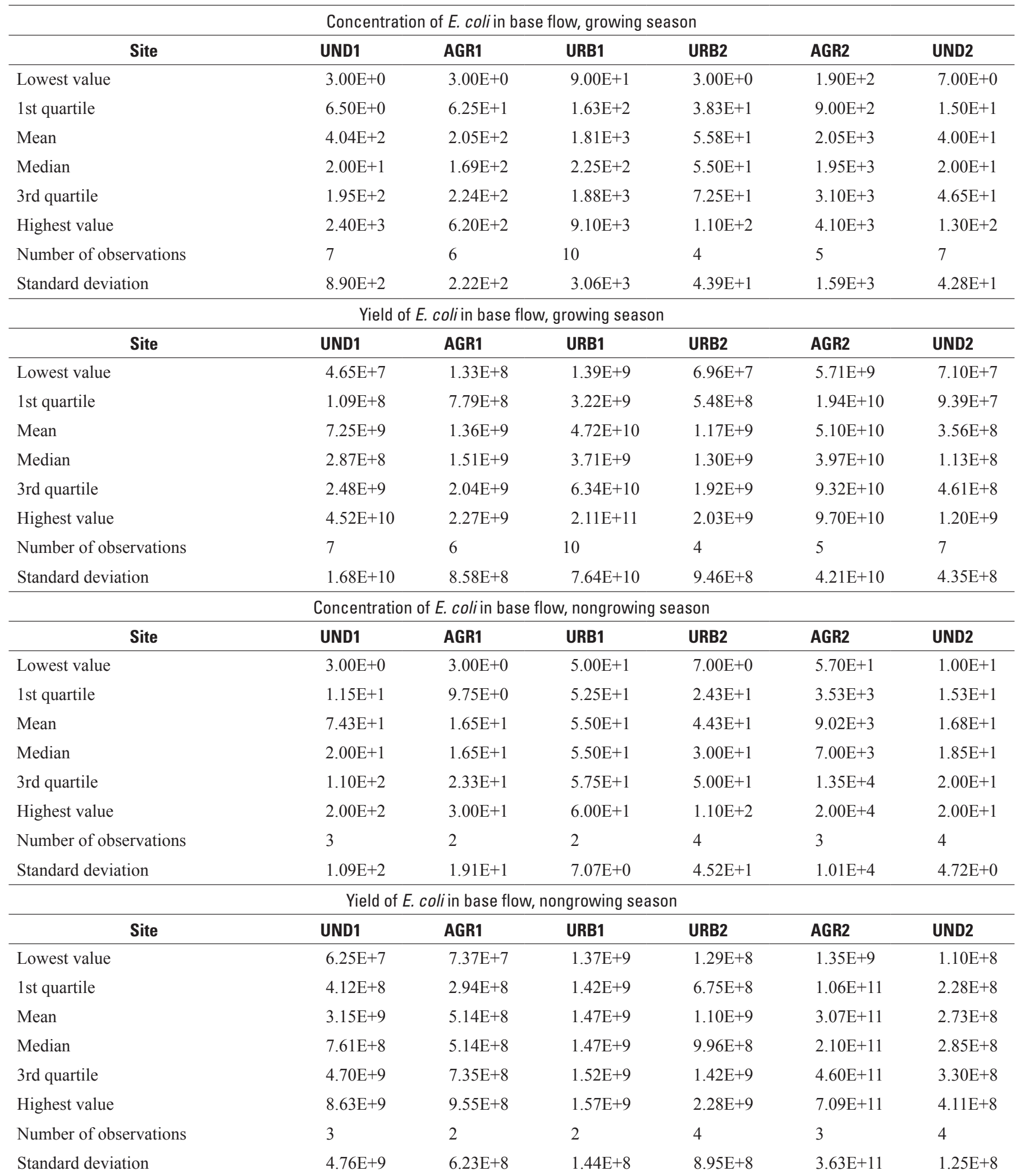


Appendix 1. Summary statistics for concentrations and yields of selected constituents, by base flow, stormflow, growing season, and nongrowing season, in samples from six streams in the lower Delaware River Basin, New Jersey, years 2002-07.-Continued

[Concentrations are in micrograms per liter except bacteria, which are in most probable number per deciliter; yields are in pounds per day per square mile; site locations are given in Fig. 2]

\begin{tabular}{|c|c|c|c|c|c|c|}
\hline \multicolumn{7}{|c|}{ Concentration of E. coli in stormflow, growing season } \\
\hline Site & UND1 & AGR1 & URB1 & URB2 & AGR2 & UND2 \\
\hline Lowest value & $1.00 \mathrm{E}+1$ & $3.00 \mathrm{E}+0$ & $1.90 \mathrm{E}+2$ & $9.30 \mathrm{E}+1$ & $4.40 \mathrm{E}+2$ & $3.00 \mathrm{E}+0$ \\
\hline Mean & $2.68 \mathrm{E}+3$ & $6.19 \mathrm{E}+3$ & $7.80 \mathrm{E}+3$ & $6.57 \mathrm{E}+3$ & $7.49 \mathrm{E}+4$ & $4.02 \mathrm{E}+3$ \\
\hline Median & $1.20 \mathrm{E}+3$ & $2.80 \mathrm{E}+3$ & $5.50 \mathrm{E}+3$ & $3.45 \mathrm{E}+3$ & $1.97 \mathrm{E}+4$ & $5.25 \mathrm{E}+2$ \\
\hline Highest value & $1.41 \mathrm{E}+4$ & $4.20 \mathrm{E}+4$ & $3.40 \mathrm{E}+4$ & $3.77 \mathrm{E}+4$ & $8.50 \mathrm{E}+5$ & $1.98 \mathrm{E}+4$ \\
\hline Number of observations & 37 & 41 & 37 & 28 & 23 & 22 \\
\hline Standard deviation & $3.26 \mathrm{E}+3$ & $9.04 \mathrm{E}+3$ & $7.79 \mathrm{E}+3$ & $8.80 \mathrm{E}+3$ & $1.73 \mathrm{E}+5$ & $6.33 \mathrm{E}+3$ \\
\hline \multicolumn{7}{|c|}{ Yield of E. coli in stormflow, growing season } \\
\hline Mean & $2.60 \mathrm{E}+11$ & $9.70 \mathrm{E}+11$ & $1.30 \mathrm{E}+12$ & $7.10 \mathrm{E}+11$ & $9.90 \mathrm{E}+12$ & $5.30 \mathrm{E}+10$ \\
\hline Median & $6.20 \mathrm{E}+10$ & $9.70 \mathrm{E}+10$ & $5.40 \mathrm{E}+11$ & $2.20 \mathrm{E}+11$ & $8.00 \mathrm{E}+11$ & $1.30 \mathrm{E}+10$ \\
\hline 3rd quartile & $3.30 \mathrm{E}+11$ & $7.50 \mathrm{E}+11$ & $2.20 \mathrm{E}+12$ & $5.90 \mathrm{E}+11$ & $8.20 \mathrm{E}+12$ & $7.80 \mathrm{E}+10$ \\
\hline Highest value & $2.70 \mathrm{E}+12$ & $1.20 \mathrm{E}+13$ & $4.60 \mathrm{E}+12$ & $4.20 \mathrm{E}+12$ & $1.20 \mathrm{E}+14$ & $3.10 \mathrm{E}+11$ \\
\hline Number of observations & 37 & 41 & 37 & 28 & 23 & 22 \\
\hline Standard deviation & $5.00 \mathrm{E}+11$ & $2.20 \mathrm{E}+12$ & $1.30 \mathrm{E}+12$ & $1.10 \mathrm{E}+12$ & $2.50 \mathrm{E}+13$ & $8.40 \mathrm{E}+10$ \\
\hline \multicolumn{7}{|c|}{ Concentration of E. coli in stormflow, nongrowing season } \\
\hline Site & UND1 & AGR1 & URB1 & URB2 & AGR2 & UND2 \\
\hline Number of observations & 15 & 10 & 12 & 15 & 17 & 20 \\
\hline Standard deviation & $1.55 \mathrm{E}+3$ & $1.03 \mathrm{E}+2$ & $5.95 \mathrm{E}+3$ & $2.65 \mathrm{E}+3$ & $7.75 \mathrm{E}+4$ & $7.86 \mathrm{E}+2$ \\
\hline \multicolumn{7}{|c|}{ Yield of E. coli in stormflow, nongrowing season } \\
\hline Site & UND1 & AGR1 & URB1 & URB2 & AGR2 & UND2 \\
\hline Lowest value & $9.60 \mathrm{E}+8$ & $6.30 \mathrm{E}+8$ & $1.50 \mathrm{E}+10$ & $3.10 \mathrm{E}+9$ & $1.90 \mathrm{E}+10$ & $4.70 \mathrm{E}+8$ \\
\hline 1st quartile & $3.10 \mathrm{E}+9$ & $4.00 \mathrm{E}+9$ & $4.80 \mathrm{E}+10$ & $3.80 \mathrm{E}+9$ & $5.90 \mathrm{E}+11$ & $1.30 \mathrm{E}+9$ \\
\hline Mean & $1.60 \mathrm{E}+11$ & $1.20 \mathrm{E}+10$ & $1.30 \mathrm{E}+12$ & $6.70 \mathrm{E}+11$ & $5.40 \mathrm{E}+12$ & $2.60 \mathrm{E}+10$ \\
\hline Median & $9.30 \mathrm{E}+9$ & $1.10 \mathrm{E}+10$ & $8.10 \mathrm{E}+10$ & $1.30 \mathrm{E}+10$ & $1.00 \mathrm{E}+12$ & $1.40 \mathrm{E}+10$ \\
\hline 3rd quartile & $1.60 \mathrm{E}+10$ & $1.60 \mathrm{E}+10$ & $2.00 \mathrm{E}+12$ & $9.00 \mathrm{E}+11$ & $6.60 \mathrm{E}+12$ & $4.40 \mathrm{E}+10$ \\
\hline Highest value & $1.40 \mathrm{E}+12$ & $2.50 \mathrm{E}+10$ & $6.60 \mathrm{E}+12$ & $3.80 \mathrm{E}+12$ & $2.60 \mathrm{E}+13$ & $9.50 \mathrm{E}+10$ \\
\hline Number of observations & 15 & 10 & 12 & 15 & 17 & 20 \\
\hline Standard deviation & $4.0 \mathrm{E}+11$ & $8.80 \mathrm{E}+9$ & $2.20 \mathrm{E}+12$ & $1.20 \mathrm{E}+12$ & $8.30 \mathrm{E}+12$ & $2.80 \mathrm{E}+10$ \\
\hline
\end{tabular}


For additional information, write to:

Director

U.S. Geological Survey

New Jersey Water Science Center

Mountain View Office Park

810 Bear Tavern Rd., Suite 206

West Trenton, NJ 08628

or visit our Web site at:

http://nj.usgs.gov/ 


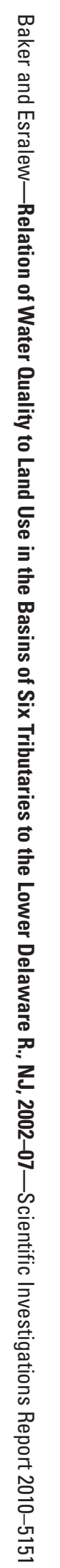

